\title{
US surface ozone trends and extremes from 1980 to 2014: quantifying the roles of rising Asian emissions, domestic controls, wildfires, and climate
}

\author{
Meiyun Lin ${ }^{1,2}$, Larry W. Horowitz ${ }^{2}$, Richard Payton ${ }^{3}$, Arlene M. Fiore ${ }^{4}$, and Gail Tonnesen ${ }^{3}$ \\ ${ }^{1}$ Atmospheric and Oceanic Sciences, Princeton University, Princeton, NJ 08540, USA \\ ${ }^{2}$ NOAA Geophysical Fluid Dynamics Laboratory, Princeton, NJ 08540, USA \\ ${ }^{3}$ US Environmental Protection Agency, Region 8, Air Program, Denver, CO 80202, USA \\ ${ }^{4}$ Lamont-Doherty Earth-Observatory and Department of Earth and Environmental Sciences, \\ Columbia University, Palisades, NY 10964, USA
}

Correspondence to: Meiyun Lin (meiyun.lin@ noaa.gov)

Received: 4 December 2016 - Discussion started: 7 December 2016

Revised: 2 February 2017 - Accepted: 6 February 2017 - Published: 1 March 2017

\begin{abstract}
US surface $\mathrm{O}_{3}$ responds to varying global-toregional precursor emissions, climate, and extreme weather, with implications for designing effective air quality control policies. We examine these conjoined processes with observations and global chemistry-climate model (GFDLAM3) hindcasts over 1980-2014. The model captures the salient features of observed trends in daily maximum $8 \mathrm{~h}$ average $\mathrm{O}_{3}$ : (1) increases over East Asia (up to $2 \mathrm{ppb} \mathrm{yr}^{-1}$ ), (2) springtime increases at western US (WUS) rural sites (0.2-0.5 $\mathrm{ppb} \mathrm{yr}^{-1}$ ) with a baseline sampling approach, and (3) summertime decreases, largest at the 95th percentile, and wintertime increases in the 50th to 5th percentiles over the eastern US (EUS). Asian $\mathrm{NO}_{x}$ emissions have tripled since 1990 , contributing as much as $65 \%$ to modeled springtime background $\mathrm{O}_{3}$ increases $\left(0.3-0.5 \mathrm{ppb} \mathrm{yr}^{-1}\right)$ over the WUS, outpacing $\mathrm{O}_{3}$ decreases attained via $50 \%$ US $\mathrm{NO}_{x}$ emission controls. Methane increases over this period contribute only $15 \%$ of the WUS background $\mathrm{O}_{3}$ increase. Springtime $\mathrm{O}_{3}$ observed in Denver has increased at a rate similar to remote rural sites. During summer, increasing Asian emissions approximately offset the benefits of US emission reductions, leading to weak or insignificant observed $\mathrm{O}_{3}$ trends at WUS rural sites. Mean springtime $\mathrm{WUS}_{3}$ is projected to increase by $\sim 10$ ppb from 2010 to 2030 under the RCP8.5 global change scenario. While historical wildfire emissions can enhance summertime monthly mean $\mathrm{O}_{3}$ at individual sites by 2-8 ppb, high temperatures and the associated buildup of $\mathrm{O}_{3}$ produced from regional anthropogenic emissions contribute
\end{abstract}

most to elevating observed summertime $\mathrm{O}_{3}$ throughout the USA. GFDL-AM3 captures the observed interannual variability of summertime EUS $\mathrm{O}_{3}$. However, $\mathrm{O}_{3}$ deposition sink to vegetation must be reduced by $35 \%$ for the model to accurately simulate observed high- $\mathrm{O}_{3}$ anomalies during the severe drought of 1988. Regional $\mathrm{NO}_{x}$ reductions alleviated the $\mathrm{O}_{3}$ buildup during the recent heat waves of 2011 and 2012 relative to earlier heat waves (e.g., 1988, 1999). The $\mathrm{O}_{3}$ decreases driven by $\mathrm{NO}_{x}$ controls were more pronounced in the southeastern US, where the seasonal onset of biogenic isoprene emissions and $\mathrm{NO}_{x}$-sensitive $\mathrm{O}_{3}$ production occurs earlier than in the northeast. Without emission controls, the 95th percentile summertime $\mathrm{O}_{3}$ in the EUS would have increased by $0.2-0.4 \mathrm{ppb} \mathrm{yr}^{-1}$ over $1988-2014$ due to more frequent hot extremes and rising biogenic isoprene emissions.

\section{Introduction}

Within the United States, ground-level $\mathrm{O}_{3}$ has been recognized since the 1940s and 1950s as an air pollutant detrimental to public health. Decreases in summertime $\mathrm{O}_{3}$ were observed in parts of California and throughout the EUS (e.g., Cooper et al., 2012; Simon et al., 2015), following regional $\mathrm{NO}_{x}$ controls after the lowering of the US National Ambient Air Quality Standard (NAAQS) for $\mathrm{O}_{3}$ in 1997 to $84 \mathrm{ppb}$. On the basis of health evidence, the NAAQS level for $\mathrm{O}_{3}$ 
has been further lowered to $75 \mathrm{ppb}$ in 2008 and to $70 \mathrm{ppb}$ in 2015 (Federal Register, 2015). There are concerns that rising Asian emissions and global methane (Jacob et al., 1999; Lin et al., 2015b), more frequent large wildfires in summer (e.g., Jaffe, 2011; Yang et al., 2015; Abatzoglou et al., 2016), and late spring deep stratospheric $\mathrm{O}_{3}$ intrusions (Lin et al., 2012a, 2015a; Langford et al., 2014) may pose challenges in attaining more stringent $\mathrm{O}_{3}$ standards in high-elevation WUS regions. A warming climate would also offset some of the air quality improvements gained from regional emission controls (e.g., Fiore et al., 2015). Quantitative understanding of sources of $\mathrm{O}_{3}$ variability on daily to multi-decadal timescales can provide valuable information to air quality control managers as they develop $\mathrm{O}_{3}$ abatement strategies under the NAAQS. Here we systemically investigate the response of US surface $\mathrm{O}_{3}$ means and extremes to changes in Asian and North American anthropogenic emissions, global methane, regional heat waves, and wildfires over the course of 35 years from 1980 to 2014, using observations and chemistry-climate model (GFDL-AM3) hindcasts (Lin et al., 2014, 2015a, b).

Rapid economic growth has led to a tripling of $\mathrm{O}_{3}$ precursor emissions from Asia in the past 25 years (e.g., Granier et al., 2011; Hilboll et al., 2013). Observed $1 \mathrm{~h} \mathrm{O} 3$ mixing ratios can frequently reach $200-400 \mathrm{ppb}$ during regional pollution episodes in eastern China (Wang et al., 2006; Li et al., 2016), with a seasonal peak in the late spring to early summer (Wang et al., 2008; Lin et al., 2009). A synthesis of available observations from the mid-1990s to the 2000s indicates increases of $1-2 \mathrm{ppb} \mathrm{yr}^{-1}$ in spring to summer $\mathrm{O}_{3}$ in China (Ding et al., 2008; Ma et al., 2016; Sun et al., 2016). Longrange transport of Asian pollution plumes towards western North America has been identified by aircraft and satellite measurements and in chemical transport models (e.g., Jaffe et al., 1999; Fiore et al., 2009; Brown-Steiner and Hess, 2011; Lin et al., 2012b; Huang et al., 2013; Verstraeten et al., 2015). Systematic comparison of observed and modeled long-term $\mathrm{O}_{3}$ trends over Asia is lacking in the published literature but is needed to establish confidence in models used to assess the global impacts of rising Asian emissions.

Model simulations indicate that import of Asian pollution enhances mean WUS surface $\mathrm{O}_{3}$ in spring by $\sim 5 \mathrm{ppb}$ (Zhang et al., 2008; Lin et al., 2012b), and occasionally contributes $8-15 \mathrm{ppb}$ during springtime pollution episodes observed at rural sites (Lin et al., 2012b) as supported by in situ aerosol composition analysis (VanCuren and Gustin, 2015). Stratospheric intrusions can episodically increase daily $8 \mathrm{~h}$ average surface $\mathrm{O}_{3}$ by $20-40 \mathrm{ppb}$, contributing to the highest observed $\mathrm{O}_{3}$ events at high-elevation WUS sites (Lin et al., 2012a, 2015a), in addition to pollution transport from California (e.g., Langford et al., 2010). In the densely populated EUS, both changes in regional anthropogenic emissions and air pollution meteorology have the greatest impacts on summer surface $\mathrm{O}_{3}$ during pollution episodes (e.g., Jacob and Winner 2009; Rieder et al., 2015; Porter et al., 2015; Pusede et al., 2015). Discerning directly the effect of climate change on air quality from long-term observation records of $\mathrm{O}_{3}$ would be ideal, but concurrent trends in precursor emissions and large internal variability in regional climate impede such an effort. It is difficult to separate the impacts of changes in global-to-regional precursor emissions and different meteorological factors on $\mathrm{O}_{3}$ at given locations without the benefit of multiple sensitivity experiments afforded by models.

On the other hand, process-oriented assessments of the models are needed to build confidence in their utility for assessing pollution control strategies, estimating tropospheric $\mathrm{O}_{3}$ radiative forcing and projecting pollution extremes under future climate scenarios (e.g., Monks et al., 2015). A number of studies show that global models capture observed decreases in summertime $\mathrm{O}_{3}$ over the EUS during 19902010, but have difficulty simulating $\mathrm{O}_{3}$ increases measured at remote high-elevation sites that are believed to represent hemispheric-scale conditions with little influence from fresh local pollution (hereafter referred to as "baseline") (e.g., Lamarque et al., 2010; Koumoutsaris and Bey, 2012; Parrish et al., 2014; Brown-Steiner et al., 2015; Strode et al., 2015). Recently, Lin et al. (2015b) examined the representativeness of $\mathrm{O}_{3}$ trends derived from sparse measurements in the free troposphere over the WUS, originally reported by Cooper et al. (2010) and used in prior model evaluations. They found that discrepancies between observed and simulated $\mathrm{O}_{3}$ trends reflect measurement sampling biases. Here we seek additional insights into the causes of the modelobservation disagreement at the WUS rural sites with continuous, high-frequency measurements. Notably, we reconcile observed and simulated $\mathrm{O}_{3}$ trends at these sites with a baseline sampling approach in the model.

Our goal in this paper is 2-fold: first, to systematically evaluate how well the GFDL-AM3 model represents trends and variability of surface $\mathrm{O}_{3}$ observed at rural sites across the US; second, to examine changes in US surface $\mathrm{O}_{3}$ means and extremes in a suite of multi-decadal hindcast simulations designed to isolate the response of $\mathrm{O}_{3}$ to increases in Asian anthropogenic emissions, North American emission controls, rising global methane, wildfires, and interannual variability in meteorology. We examine trends across the entire probability distribution of $\mathrm{O}_{3}$ concentration, which is crucial to assessing the ability of models to simulate the surface $\mathrm{O}_{3}$ response under different temperature and chemical regimes depending on seasons, geographical location, and regional transport patterns. Specifically, we evaluate the trends separately for the 5th, 50th and 95th percentiles of the $\mathrm{O}_{3}$ concentration distribution in spring (MAM), summer (JJA), autumn (SON), and winter (DJF).

Section 2 briefly describes the observational records, model experiments, and analysis approach. As a first step towards assessing our understanding of the impacts of rising Asian emissions, we briefly review Asian $\mathrm{O}_{3}$ trends from observations in recent publications and evaluate modeled trends (Sect. 3). We then focus our analysis on the US, using both observations and models to assess the response of 
US surface $\mathrm{O}_{3}$ to changes in background $\mathrm{O}_{3}$, regional anthropogenic emissions and meteorology (Sect. 4). In Sect. 5, we further separate the influence of background on WUS $\mathrm{O}_{3}$ into components driven by rising Asian anthropogenic emissions, global methane, and wildfires. We quantify the contribution of these factors to surface $\mathrm{O}_{3}$ in both rural areas such as national parks (Sect. 5.1 to 5.3) and in densely populated regions such as the Denver metropolitan area (Sect. 5.4). After evaluating historical trends, we additionally draw upon two simulations following the 21 st century RCP4.5 versus RCP8.5 global change scenarios to project WUS $\mathrm{O}_{3}$ through 2050 (Sect. 5.2). Section 6 examines how the EUS summertime $\mathrm{O}_{3}$ probability distribution and pollution extremes respond to large-scale heat waves, droughts, and regional $\mathrm{NO}_{x}$ reductions over the past decade, and how well our model simulates the observed features. Finally, we summarize in Sect. 7 the key drivers of US surface $\mathrm{O}_{3}$ trends and extremes and discuss the implications of this study.

\section{Model and observations}

\subsection{Chemistry-climate model experiments}

The GFDL-AM3 model includes interactive stratospheretroposphere chemistry and aerosols on a cubed sphere grid with a resolution of approximately $200 \times 200 \mathrm{~km}^{2}$ (Donner et al., 2011). Table 1 summarizes the meteorology, radiative forcing agents, and emissions used in each experiment. The hindcast simulations (1979-2014) are nudged to the NCEP/NCAR reanalysis zonal and meridional winds using a height-dependent nudging technique (Lin et al., 2012b). Biogenic isoprene emissions and lightning $\mathrm{NO}_{x}$ are tied to model meteorology (Guenther et al., 2006; Rasmussen et al., 2012) and thus can respond to changes in climate, whereas soil $\mathrm{NO}_{x}$ and chemical dry deposition velocities are set to a monthly climatology (Naik et al., 2013), with a diurnal cycle applied for $\mathrm{O}_{3}$ dry deposition. To investigate the possible influence of drought on $\mathrm{O}_{3}$ removal (e.g., Emberson et al., 2013), we additionally conduct a sensitivity simulation for 1988 with reduced $\mathrm{O}_{3}$ deposition velocity (see Sect. 6). Our BASE simulation and two additional simulations with modified emissions (FIXEMIS and IAVFIRE) were previously used to interpret the causes of increasing autumnal $\mathrm{O}_{3}$ measured at Mauna Loa Observatory in Hawaii since 1974 (Lin et al., 2014), interannual variability of springtime $\mathrm{O}_{3}$ (Lin et al., 2015a) and the representativeness of free tropospheric $\mathrm{O}_{3}$ measurements over the WUS (Lin et al., 2015b).

With anthropogenic emissions and methane held constant (Table 1), the FIXEMIS and IAVFIRE simulations isolate the influence from meteorology and wildfire emissions, respectively. In IAVASIA, anthropogenic emissions from East Asia $\left(15-50^{\circ} \mathrm{N}, 95-160^{\circ} \mathrm{E}\right)$ and South Asia (5-35 $\mathrm{N}, 50$ $95^{\circ} \mathrm{E}$ ) are allowed to vary from year to year as in BASE, while anthropogenic emissions in the other regions of the world, global methane and wildfire emissions are held constant as in FIXEMIS. In $\mathrm{IAVCH}_{4}$, global methane is allowed to vary over time as in BASE, but with anthropogenic and wildfire emissions held constant as in FIXEMIS. The IAVASIA and $\mathrm{IAVCH}_{4}$ simulations thus isolate the role of rising Asian anthropogenic emissions and global methane, respectively, by contrasting with the FIXEMIS simulation. Both BASE and $\mathrm{IAVCH}_{4}$ simulations apply observed time-varying methane concentrations as a lower boundary condition for chemistry (Supplement Fig. S1). Thus, underestimates in historical methane emissions reported recently by Schwietzke et al. (2016) do not affect our results. We quantify the total contributions to surface $\mathrm{O}_{3}$ from meteorological variability, stratosphere-to-troposphere transport, pollution from foreign continents and $\mathrm{O}_{3}$ produced by global methane, lightning $\mathrm{NO}_{x}$, wildfires and biogenic emissions with the Background simulation, in which North American anthropogenic emissions are zeroed out relative to BASE. We additionally draw upon two simulations with the GFDL Coupled Model CM3 following the 21st century RCP global change scenarios to project changes in $\mathrm{WUS}_{3}$ through 2050. Details of these CM3 simulations were described in John et al. (2012).

\subsection{Anthropogenic and biomass burning emissions}

We first examine how well the emission inventories in AM3 BASE represent changes in regional $\mathrm{NO}_{x}$ emissions over recent decades inferred from satellite measurements of tropospheric vertical column density $\left(\mathrm{VCD}_{\text {trop }}\right)$ of $\mathrm{NO}_{2}$. The combined record of GOME and SCIAMACHY shows that $\mathrm{VCD}_{\text {trop }} \mathrm{NO}_{2}$ over the highly polluted region of eastern China almost tripled during 1996-2011 (Fig. 1a). In contrast, $\mathrm{VCD}_{\text {trop }} \mathrm{NO}_{2}$ over the EUS decreased by $\sim 50 \%$ in the 2000s (Fig. 1b) due to $\mathrm{NO}_{x}$ State Implementation Plans (commonly known as the $\mathrm{NO}_{x}$ SIP Call) and many rules that tighten emission standards for mobile sources (McDonald et al., 2012). Similar decreases occurred in WUS cities, resulting from the $\mathrm{NO}_{x}$ control programs to achieve $\mathrm{O}_{3}$ and regional haze planning goals. These trends are consistent with those reported by a few recent studies (e.g., Hilboll et al., 2013), including those using $\mathrm{OMI} \mathrm{NO}_{2}$ data (Russell et al., 2012; Duncan et al., 2016). For comparison with satellite data, we sample the model archived every $3 \mathrm{~h}$ closest to the time of satellite overpass for the SCIAMACHY and GOME products we use in Fig. 1 (10:00-10:30 local time). Trends in $\mathrm{VCD}_{\text {trop }} \mathrm{NO}_{2}$ are similar to those in $\mathrm{NO}_{x}$ emissions (orange lines versus red triangles in Fig. 1a-b), indicating that any changes in $\mathrm{NO}_{x}$ chemical lifetime or partitioning have negligible influence in our model, consistent with $\mathrm{NO}_{2}$ loss against $\mathrm{OH}$ being minor during the morning overpasses of GOME and SCIAMACHY. The emission inventory used in BASE, from Lamarque et al. (2010) with annual interpolation after 2000 to RCP8.5 (Lamarque et al., 2012), mimics the opposing changes in $\mathrm{NO}_{x}$ emissions over eastern China versus the EUS during 1996-2011, consistent with 
Table 1. Summary of forcings and emissions used in AM3 hindcasts and CM3 projections.

\begin{tabular}{|c|c|c|c|c|c|c|}
\hline Experiment & Time periods & Meteorology & Radiative forcings & $\mathrm{CH}_{4}$ (chemistry) & Anthropogenic emissions & Fire emissions \\
\hline BASE & 1979-2014 & Nudged to NCEP & Historical & Historical & Historical & Historical \\
\hline Background & 1979-2014 & As BASE & Historical & Historical & $\begin{array}{l}\text { Zeroed out in N. America; } \\
\text { as in BASE elsewhere }\end{array}$ & Historical \\
\hline FIXEMIS & 1979-2014 & As BASE & Historical & 2000 & Constant $^{1}$ & Constant $^{1}$ \\
\hline IAVFIRE & 1979-2014 & As BASE & Historical & 2000 & Constant $^{1}$ & Historical \\
\hline IAVASIA & $1979-2012^{2}$ & As BASE & Historical & 2000 & $\begin{array}{l}\text { Varying in Asia as in BASE; } \\
\text { as in FIXEMIS elsewhere }\end{array}$ & Constant $^{1}$ \\
\hline $\mathrm{IAVCH}_{4}$ & $1979-2012^{2}$ & As BASE & Historical & Historical & Constant $^{1}$ & Constant $^{1}$ \\
\hline CM3_RCP4.5 & 2005-2050 & Free running & $\mathrm{RCP} 4.5$ & $\mathrm{RCP} 4.5$ & $\mathrm{RCP} 4.5$ & $\mathrm{RCP} 4.5$ \\
\hline CM3_RCP8.5 & $2005-2050$ & Free running & $\mathrm{RCP} 8.5$ & $\mathrm{RCP} 8.5$ & $\mathrm{RCP} 8.5$ & $\mathrm{RCP} 8.5$ \\
\hline
\end{tabular}

${ }^{1}$ Averaged over the whole $1970-2010$ period. ${ }^{2}$ Note that the IAVASIA and $\mathrm{IAVCH}_{4}$ simulations only extend to 2012.
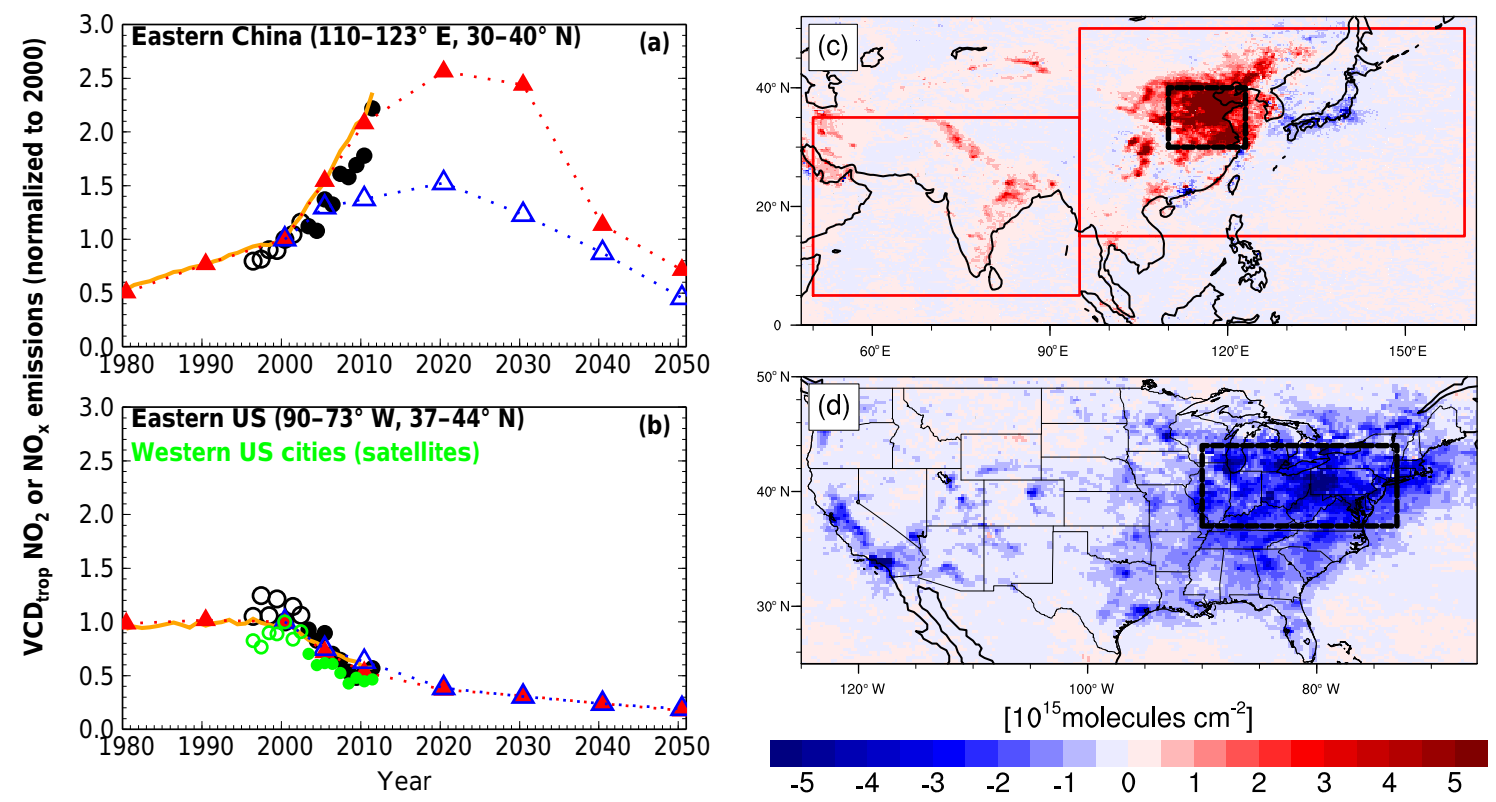

Figure 1. Changes in $\mathrm{NO}_{x}$ emissions. (a-b) Mean annual vertical column densities of tropospheric (VCDtrop) $\mathrm{NO}_{2}$ normalized to the year 2000 for the eastern China and eastern US domains (black boxes on map) from GOME (1996-2002, open circles) and SCIAMACHY (20032011, closed circles) measurements and AM3 BASE simulations (orange lines). Triangles indicate trends in $\mathrm{NO}_{x}$ emissions (normalized to 2000) from Lamarque et al. (2010) with annual interpolation after 2000 to RCP8.5 (red) versus RCP4.5 (blue). (c-d) Differences in annual mean SCIAMACHY VCDtrop $\mathrm{NO}_{2}$ from 2003-2005 to 2009-2011. The red boxes denote the regions where emissions vary over time in the IAVASIA simulation (Table 1). Satellite $\mathrm{NO}_{2}$ data are from www.temis.nl, with the retrieval technique described in Boersma et al. (2004).

changes in $\mathrm{VCD}_{\text {trop }} \mathrm{NO}_{2}$ retrieved from the satellite instruments. For comparison, the RCP4.5 interpolation for 20012010 in CMIP5 historical simulations analyzed by Parrish et al. (2014) underestimates the increase in Chinese $\mathrm{NO}_{x}$ emissions by a factor of 2 (Fig. 1a). Recent reductions in Chinese $\mathrm{NO}_{x}$ emissions after 2011 (Duncan et al., 2016) are not represented in the inventories used in AM3.

Our BASE model applies interannually varying monthly mean emissions from biomass burning based on the RETRO inventory (Schultz et al., 2008) for 1970 to 1996 and GFEDv3 (van der Werf et al., 2010) for 1997 onwards, distributed vertically as recommend by Dentener et al. (2006).
Figure S2 illustrates the interannual variability of biomass burning $\mathrm{CO}$ emissions from the main source regions of the Northern Hemisphere over the period 1980-2014. Boreal fire emissions in Eurasia almost doubled from 1980-1995 to 1996-2014, with large fires occurring more frequently in the recent decade, as found for the WUS (Dennison et al., 2014; Yang et al., 2015).

\subsection{Ozone observation records and uncertainties}

Long-term surface $\mathrm{O}_{3}$ observation records were obtained at 70 selected rural monitoring sites with 20 (1995-2014) to 27 (1988-2014) years of continuous hourly measurements 

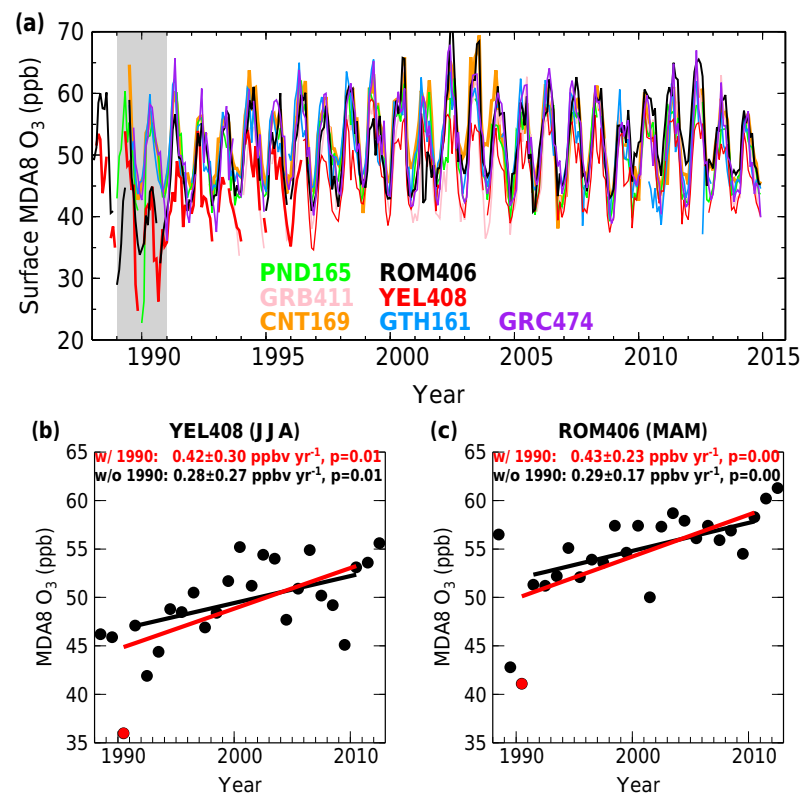

Figure 2. Measurement uncertainties. (a) Comparison of observed monthly mean MDA8 $\mathrm{O}_{3}$ at WUS CASTNet sites. All sites have more than $90 \%$ data availability in every month shown. The gray shading denotes the period when data at Yellowstone (red) and Rocky Mountain (black) were inconsistent with the other sites. (bc) The 1990-2010 trends of median JJA MDA8 $\mathrm{O}_{3}$ at Yellowstone and median MAM MDA8 $\mathrm{O}_{3}$ at Rocky Mountain with and without data in 1990 .

from the US National Park Services, the US Clean Air Status and Trends Network (CASTNet), and the US EPA Air Quality System. Cooper et al. (2012) reported trends in daytime (11:00-16:00) $\mathrm{O}_{3}$ over 1990-2010 at 53 rural sites. We investigate trends in daily maximum $8 \mathrm{~h}$ averaged (MDA8) $\mathrm{O}_{3}$ and expand the analysis of Cooper et al. (2012) using additional data to 2014 and including 17 additional sites with measurements begun in 1991-1995. All sites have at least 20 years of data. If a site has less than $50 \%$ data availability in any season, then that particular season is discarded. The trend is calculated separately for the 5th, 50th and 95th percentiles of daily MDA8 $\mathrm{O}_{3}$ for each season through ordinary linear least-square regression. Statistics are derived for the slope of the linear regression in units of $\mathrm{ppb} \mathrm{yr}^{-1}$, the range of the slope with a $95 \%$ confidence limit (not adjusted for sample autocorrelation), and the $p$ value indicating the statistical significance of the trend based on a two-tailed $t$ test.

A cross-site consistency analysis was performed to determine robust changes in the time evolution of $\mathrm{O}_{3}$ over the WUS during 1988-2014 (Fig. 2). The monitor at Yellowstone National Park was moved $1.5 \mathrm{~km}$ from the Lake Yellowstone site to the Water Tank site in 1996. While the local transport patterns are slightly different for the two sites, using MDA8 data from the well-mixed midday period minimizes the differences (Jaffe and Ray, 2007). Observed $\mathrm{O}_{3}$ interannual variations show large-scale similarity across sites over the Intermountain West except for the earlier period 19891990. During this period, observations at Yellowstone and Rocky Mountain national parks show low- $\mathrm{O}_{3}$ anomalies that do not appear at other sites, but there is no change in measurement technique. Jaffe and Ray (2007) suggest this represents large-scale variations in background $\mathrm{O}_{3}$ that are seen in common at these two parks. However, analysis of meteorological fields and model diagnostics does not reveal any obvious transport anomaly influencing $\mathrm{O}_{3}$ variations at these sites in 1990 (Lin et al., 2015a). Observations at Pinedale in January-February 1990 are also anomalously low relative to Grand Canyon (GRC474), Centennial (CNT169), and Gothic (GTH161). These anomalous data at the beginning of measurement records can substantially influence trends calculated from short records. For example, Cooper et al. (2012) found a summer $\mathrm{O}_{3}$ increase of $0.42 \pm 0.30 \mathrm{ppb} \mathrm{yr}^{-1}$ at Yellowstone over 1990-2010. Removing 1990, we find a weaker increase of $0.28 \pm 0.27 \mathrm{ppb} \mathrm{yr}^{-1}$ (Fig. 2b). Removing 1990 at Rocky Mountain resulted in a weaker springtime $\mathrm{O}_{3}$ increase of $0.29 \pm 0.17 \mathrm{ppb} \mathrm{yr}^{-1}$ compared to $0.43 \pm 0.23 \mathrm{ppb} \mathrm{yr}^{-1}$ over 1990-2010 (Fig. 2c). To assess robust $\mathrm{O}_{3}$ changes, we thus remove these apparently uncertain measurements in 1990 from the subsequent analysis.

\subsection{Model baseline sampling approach}

Springtime $\mathrm{O}_{3}$ observations at WUS high-elevation sites $(\geq 1.5 \mathrm{~km}$ a.s.l.) typically represent baseline conditions with little influence from fresh local pollution. In a global model with $\sim 200 \times 200 \mathrm{~km}^{2}$ horizontal resolution, however, these remote sites can reside in the same grid cell that contains urban cities where $\mathrm{NO}_{x}$ emissions decreased over the analysis period. For example, Rocky Mountain National Park (2.7 km a.s.1.) is less than $100 \mathrm{~km}$ from the Denver metropolitan area in Colorado. This limitation of large-scale models in resolving urban-to-rural gradients and sharp topography results in an artificial offset of increased baseline $\mathrm{O}_{3}$ at remote sites by decreased urban pollution within the same model grid cell. Thus, coarse-resolution models are often unable to reproduce observed $\mathrm{O}_{3}$ increases at the high-elevation sites representative of remote baseline conditions (Fig. 3a versus b), as found in many prior modeling analyses (e.g., Parrish et al., 2014; Strode et al., 2015, and references therein). This limitation can be addressed by using a baseline selection procedure to identify conditions for sampling the model to avoid model artifacts caused by poor spatial resolution, as described below.

All measurements presented in this study are unfiltered. We implement a set of regional CO-like tracers (COt), with a 50-day exponential decay lifetime and surface emissions constant in time from each of four northern mid-latitude source regions (Lin et al., 2014). We use these COt tracers to bin modeled $\mathrm{O}_{3}$ according to the dominant influence of different continental air regimes. To represent observed baseline conditions at WUS sites, we sample AM3 
(a) Observed

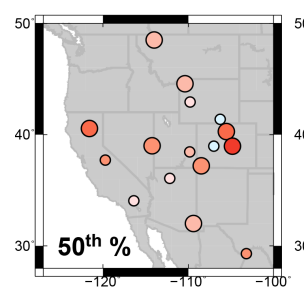

(d) BASE $700 \mathrm{hPa}$

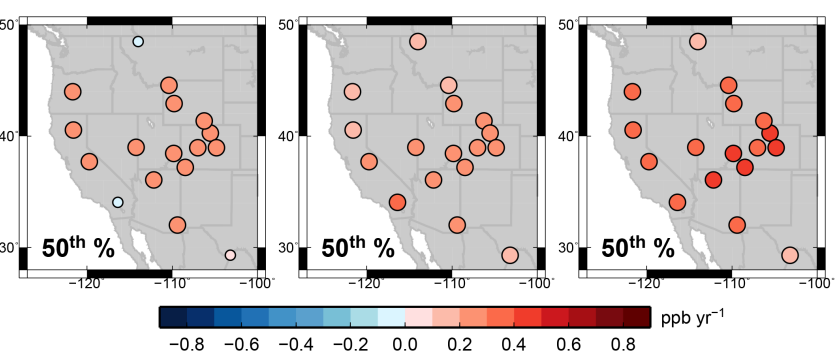

Figure 3. Influence of baseline sampling. Median spring MDA8 $\mathrm{O}_{3}$ trends over 1988-2014 at WUS sites from (a) observations, (b) BASE model sampled at the surface, (c) BASE sampled at $700 \mathrm{hPa}$ and filtered to remove the influence from fresh local pollution (see Sect. 2.4), (d) BASE sampled at $700 \mathrm{hPa}$ without filtering, and (e-f) Background (with North American anthropogenic emissions shut off) sampled at the surface versus at $700 \mathrm{hPa}$. Note that three low-elevation $(<1.5 \mathrm{~km})$ sites, Joshua Tree, Big Bend and Glacier national parks, are always sampled at the surface. Larger circles indicate sites with statistically significant trends $(p<0.05)$.

at $700 \mathrm{hPa}(\sim 3 \mathrm{~km}$ a.s.l. $)$ and filter the $\mathrm{O}_{3}$ data in the BASE simulation to remove the influence from fresh local pollution. Specifically, our filter excludes days when North American COt (NACOt) exceeds the 67th percentile for each season. This procedure yields higher calculated baseline $\mathrm{O}_{3}$ increases (Fig. 3c), bringing it closer to observations (Fig. 3a). When sampled at $700 \mathrm{hPa}$ without filtering (Fig. 3d), BASE gives statistically significant $\mathrm{O}_{3}$ increases, but the rate of increase is $\sim 0.1 \mathrm{ppb} \mathrm{yr}^{-1}$ weaker than with filtering. With North American anthropogenic emissions shut off, the model simulates significant $\mathrm{O}_{3}$ increases that are similar at the surface (Fig. 3e) and at $700 \mathrm{hPa}$ (Fig. 3f). This finding indicates that the underestimate of $\mathrm{O}_{3}$ increases in BASE, when sampled at the surface (Fig. 3b), reflects an excessive offset from domestic pollution decreases in the model relative to observed conditions, as opposed to the insufficient mixing of free tropospheric $\mathrm{O}_{3}$ to the surface. As individual sites display observed trends falling in between the filtered model, and those sampled at the surface versus aloft, we can use the model to interpret which sites most frequently sample baseline versus being influenced by North American anthropogenic emissions. For consistency, in the subsequent analysis we apply model baseline filtering to all WUS sites with elevations greater than $1.5 \mathrm{~km}$ altitude. In the EUS, where the terrain and monitor elevations are much lower than in the west and observed $\mathrm{O}_{3}$ trends are largely controlled by regional emission changes, we always sample the model at the surface without filtering.

\section{Global distribution of lower tropospheric $\mathrm{O}_{3}$ trends}

\subsection{Global $\mathrm{O}_{3}$ burden and distribution of trends}

We begin by examining the global distribution of lower tropospheric $\mathrm{O}_{3}$ trends over 1988-2014 from the BASE simulation (Fig. 4) and focus on the differences between the surface and free troposphere $(\sim 700 \mathrm{hPa})$, with implications for understanding the impact of trends in hemispheric baseline $\mathrm{O}_{3}$ on surface air quality. The model indicates that surface MDA8 $\mathrm{O}_{3}$ levels in Asia have increased significantly by $1.5-2.5 \mathrm{ppb} \mathrm{yr}^{-1}$ in the 95 th percentile (Fig. 4a-b) and by $1-$ $2 \mathrm{ppb} \mathrm{yr}^{-1}$ in the median values (Fig. $4 \mathrm{c}-\mathrm{d}$ ), with the largest increases occurring in southern Asia during spring and over eastern China during summer. In contrast, there is a marked decrease in surface MDA8 $\mathrm{O}_{3}$ in WUS cities, throughout the EUS and in central Europe, particularly at the high percentiles and during summer. The increase in surface $\mathrm{O}_{3}$ over Asia and decreases over the US and Europe are consistent with changes in regional emissions of $\mathrm{O}_{3}$ precursors over this period (Fig. 1).

Over Southeast Asia (south of $30^{\circ} \mathrm{N}$ ) during spring, earlier springtime $\mathrm{O}_{3}$ photochemical production at lower latitudes coupled with active frontal transport (Liu et al., 2002; Carmichael et al., 2003; Lin et al., 2010) leads to a comparable or even greater increase in $\mathrm{O}_{3}$ in the free troposphere than at the surface (Fig. $4 \mathrm{c}$ versus e). In contrast, over central eastern China during summer the simulated trends of $\mathrm{O}_{3}$ in the free troposphere are at least a factor of 3 weaker than in surface air (Fig. 4d versus f), consistent with the analysis of MOZAIC aircraft data over Beijing in 1995-1999 versus 2003-2005 (Ding et al., 2008). Mean $\mathrm{O}_{3}$ at $700 \mathrm{hPa}$ above parts of North America and Europe show little change in summer or even increase during spring in the model, similar to the trends at $500 \mathrm{hPa}$ (Fig. S3), despite the significant decreases in surface air. The global tropospheric $\mathrm{O}_{3}$ burden in the BASE simulation increases by approximately $30 \mathrm{Tg}$ over the past 35 years (Fig. 5a), attributed mainly to changes in anthropogenic emissions. Over the 2004-2015 OMI/MLS satellite era, however, meteorological variability contributes approximately half to the total simulated decadal trends of $\mathrm{O}_{3}$ burden (Fig. 5a), indicating that attribution of the satellite-derived decadal trends of global tropospheric $\mathrm{O}_{3}$ burden requires consideration of internal climate variability.

\subsection{Comparison of observed and simulated $\mathrm{O}_{3}$ trends in Asia}

Long-term $\mathrm{O}_{3}$ observations are very sparse in Asia, making it difficult to evaluate modeled $\mathrm{O}_{3}$ trends. We compile available measurements from the published literature, includ- 
MAM
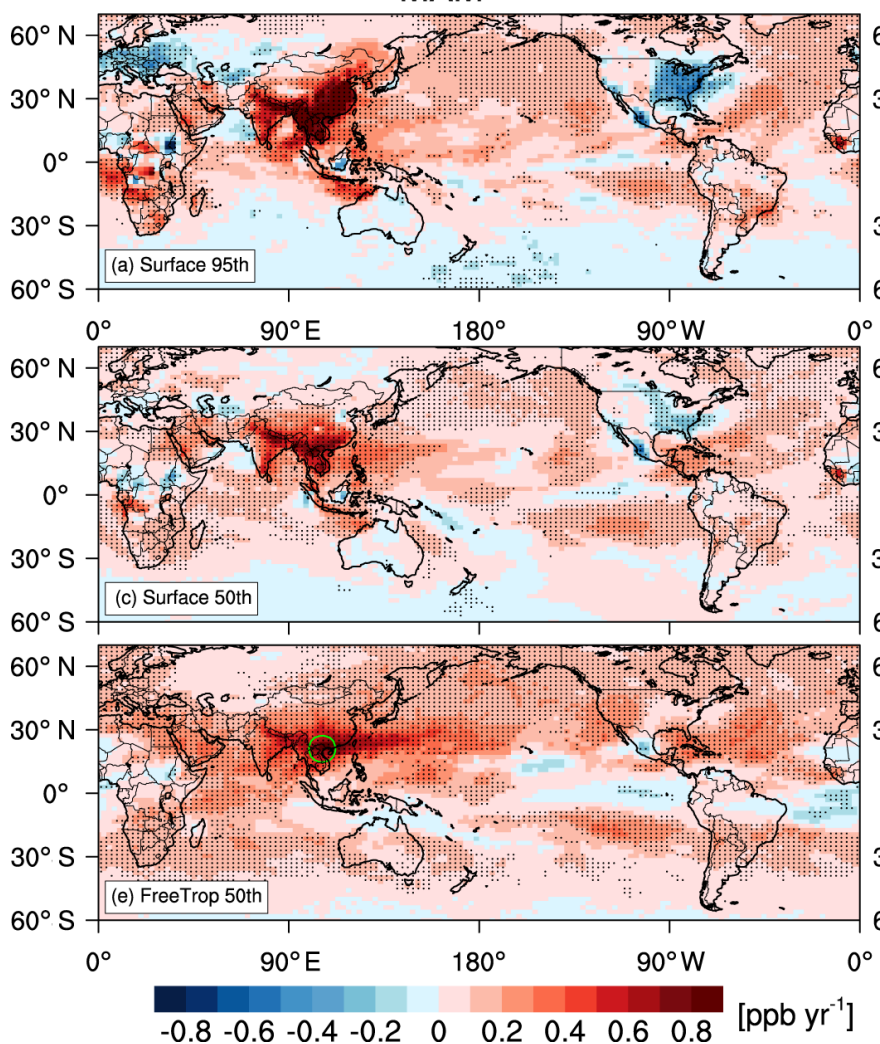

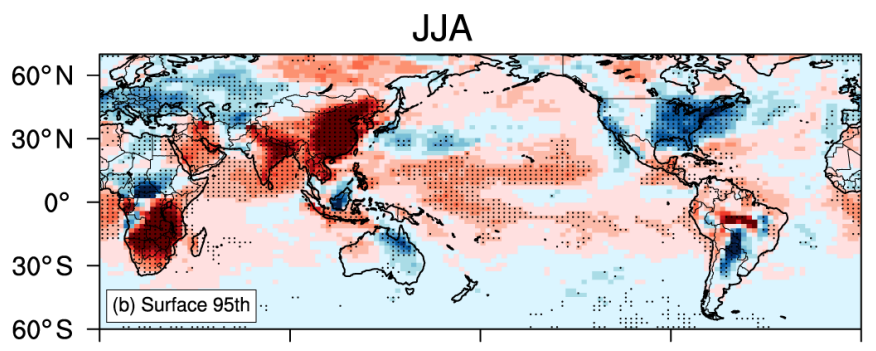

0

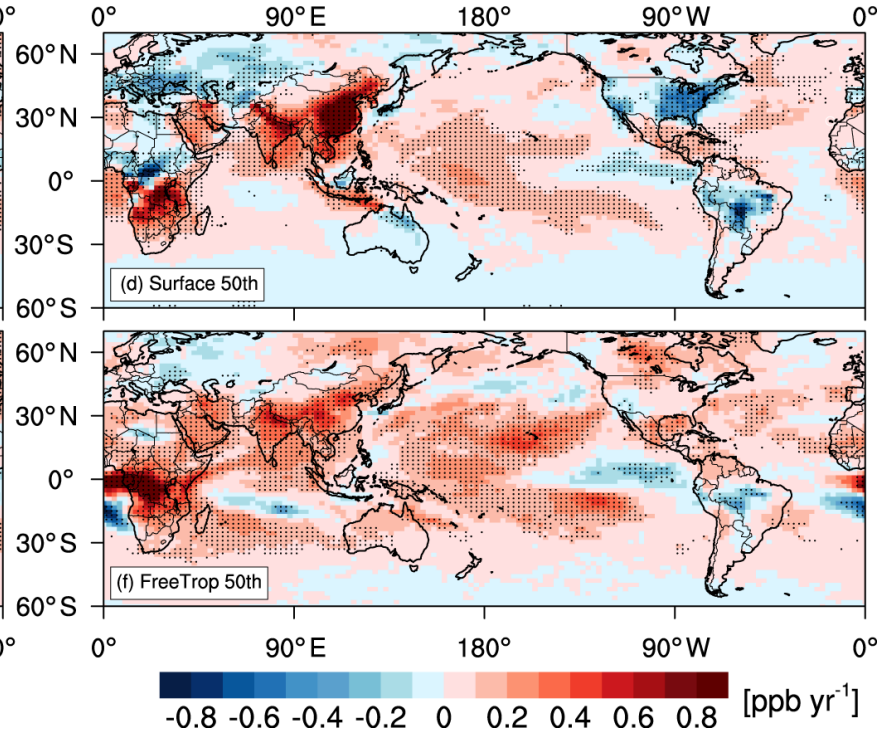

Figure 4. Global distribution of MDA8 $\mathrm{O}_{3}$ trends from AM3 BASE over 1988-2014 for boreal spring (left) and summer (right) for the 95th percentile at the surface $(\mathbf{a}-\mathbf{b})$, median at the surface $(\mathbf{c}-\mathbf{d})$, and median in the free troposphere $(700 \mathrm{hPa} ; \mathbf{e}-\mathbf{f})$. Stippling indicates areas where the trend is statistically significant $(p<0.05)$. The color scale is designed to resolve regional features rather than extreme values and saturates. The range of the trends is -1 to $+2.5 \mathrm{ppb} \mathrm{yr}^{-1}$.

ing ozonesonde profiles at Hong Kong (2000-2014; www. woudc.org) and Hanoi (2005-2015; SHADOZ, Thompson et al., 2007), MOZAIC aircraft profiles collected on summer afternoons in the boundary layer (below $1250 \mathrm{~m}$ altitude) over Beijing for 1995-2005 (Ding et al., 2008), groundbased measurements at Mt. Tai (1.5 km a.s.1.) in central eastern China for July-August 2003-2015 (Sun et al., 2016), at the GAW stations, Shangdianzi north of Beijing for 20042014 (Ma et al., 2016) and Mt. Waliguan (3.8 km a.s.l.) on the Tibetan Plateau for 1994-2013 (Xu et al., 2016), at Taiwan for 1994-2007 (Lin et al., 2010), South Korea for 19902010 (Lee et al., 2014), Mt. Happo (1.9 km a.s.l.) in Japan for 1991-2011 (Tanimoto, 2009; Parrish et al., 2014), and a coastal site at Hong Kong in southern China for 1994-2007 (Wang et al., 2009).

Recently, Zhang et al. (2016) compiled sparse $\mathrm{O}_{3}$ profiles above Southeast Asia from IAGOS commercial aircraft and ozonesondes from Hanoi for 1994-2004 versus 2005-2014 and found a total springtime $\mathrm{O}_{3}$ increase of $20-25 \mathrm{ppb}$ between the two periods $\left(\sim 2 \mathrm{ppbyr}^{-1}\right)$. However, our model indicates an increase of up to $1 \mathrm{ppbyr}^{-1}$ for free tropospheric $\mathrm{O}_{3}$ over Southeast Asia in spring (Fig. 4e). We illus- trate the possible influence of sampling deficiencies on the $\mathrm{O}_{3}$ trends inferred from sparse observations (Fig. 5). The ozonesonde frequency is four profiles per month at Hong Kong and only one to two profiles per month at Hanoi. To determine the representativeness of $\mathrm{O}_{3}$ trends derived from these sparse measurements, we compare observations and model results co-sampled on sonde launch days, with the "true average" determined from $\mathrm{O}_{3}$ fields archived every $3 \mathrm{~h}$ from the model, as in our prior work for WUS sites (Lin et al., 2015a, b). Figure 5b and c show the comparisons for the annual trends of $\mathrm{O}_{3}$ over $900-600 \mathrm{hPa}$. The trends are generally consistent across the sonde data, model cosampled and "true average" results for Hong Kong, with an increase of $0.5 \pm 0.1 \mathrm{ppb} \mathrm{yr}^{-1}$ over 2000-2014. Observations at Hanoi show an apparently rapid $\mathrm{O}_{3}$ increase of $1.1 \pm 0.2 \mathrm{ppb} \mathrm{yr}^{-1}$ over 2005-2014. AM3 BASE, when sampled sparsely as in the ozonesondes, captures the observed variability $\left(r^{2}=0.7\right)$, whereas the "true average" over this period indicates the trend $\left(0.7 \pm 0.1 \mathrm{ppb} \mathrm{yr}^{-1}\right)$ is only $63 \%$ of that inferred from observations. Moreover, interannual variability of $\mathrm{O}_{3}$ resulting from wildfire emissions and meteorology in IAVFIRE is as large as the total $\mathrm{O}_{3}$ change in 
(a) Changes in global trop. $\mathrm{O}_{3}$ burden

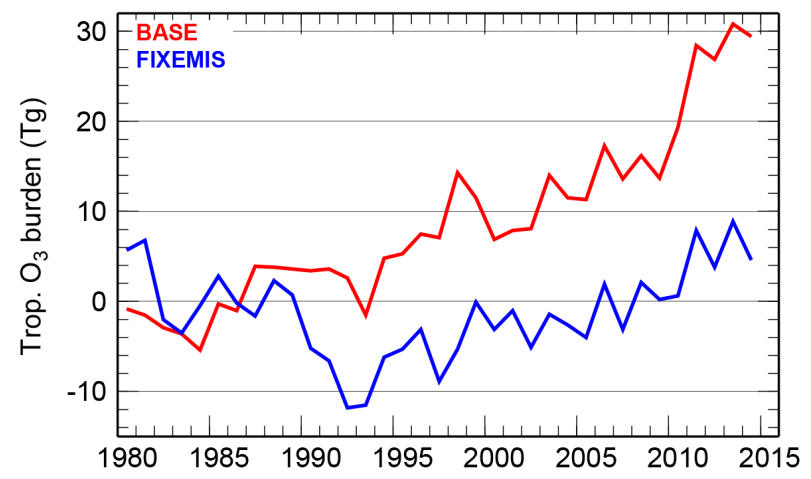

(b) Hong Kong $\left(22.3^{\circ} \mathrm{N}, 114.2^{\circ} \mathrm{E}, 900-600 \mathrm{hPa}\right)$

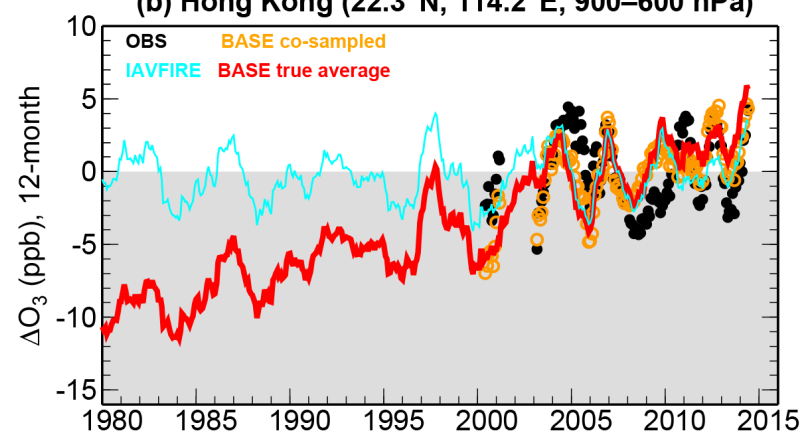

(c) Hanoi $\left(21.0^{\circ} \mathrm{N}, 105.8^{\circ} \mathrm{E}, 900-600 \mathrm{hPa}\right)$

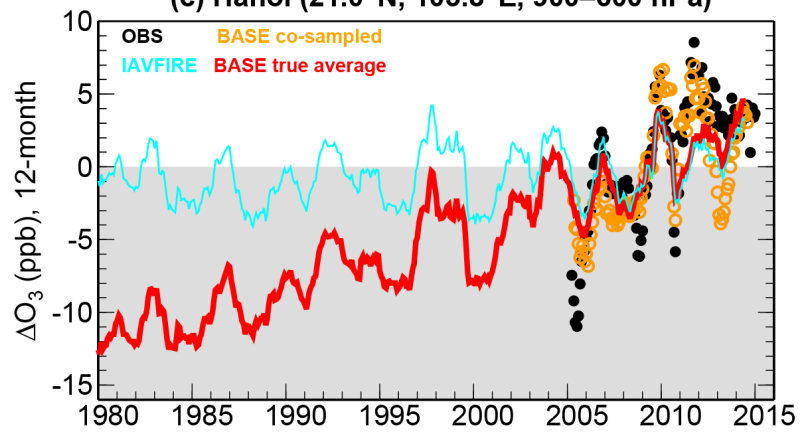

Figure 5. (a) Time series of changes in global tropospheric $\mathrm{O}_{3}$ burden relative to the 1981-1990 mean from BASE and FIXEMIS simulations (Table 1). (b) Time series of 12-month running mean anomalies (relative to the 2005-2014 mean) of $\mathrm{O}_{3}$ averaged over 900-600 hPa at Hong Kong from the averages of ozonesonde samples (black circles) and the BASE model co-sampled on sonde launch days (orange circles) versus the true average from BASE and IAVFIRE with continuous daily sampling (solid lines). (c) Same as (b), but for Hanoi.

BASE over the short period 2005-2014. We conclude that measurement sampling artifacts influence the $\mathrm{O}_{3}$ trends reported by Zhang et al. (2016).

Expanding the comparison to a suite of sites across East Asia (Fig. 6), we find that AM3 captures the key features of observed $\mathrm{O}_{3}$ trends in Asia, including their seasonal to regional variations, summertime increases $\left(1-2 \mathrm{ppb} \mathrm{yr}^{-1}\right)$ in central eastern China where $\mathrm{NO}_{x}$ emissions have approxi- (a)

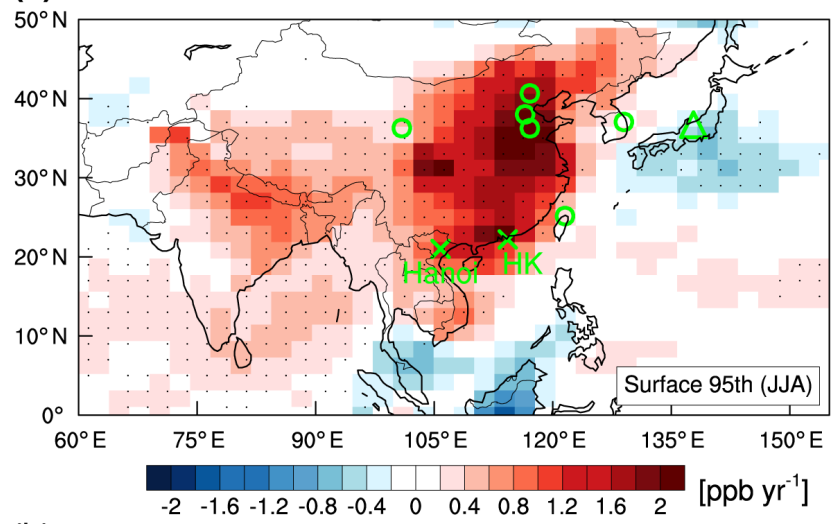

(b)

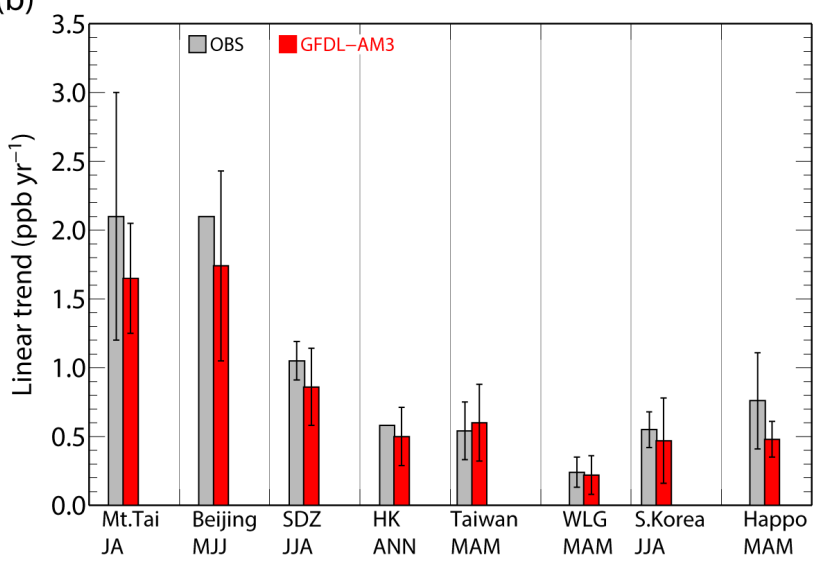

Figure 6. Surface $\mathrm{O}_{3}$ trends in Asia. (a) Observation sites superimposed on a map of the 95 th percentile summer $\mathrm{MDA} 8 \mathrm{O}_{3}$ trends over 1995-2014 from AM3 BASE. (b) Comparison of median $\mathrm{O}_{3}$ trends from AM3 (1995-2014) with observations (see text for periods): in central eastern China at Mt. Tai (July-August, Sun et al., 2016), Beijing (May-June-July, Ding et al., 2008) and Shangdianzi (SDZ) (JJA, Ma et al., 2016); in South China at Hong Kong (HK) (annual average, Wang et al., 2009) and Taiwan (MAM, Lin et al., 2010); at Mt. Waliguan (WLG) in western China (MAM, Xu et al., 2016); in South Korea (JJA, Lee et al., 2014) and Mt. Happo Japan (MAM, Tanimoto, 2009). For Mt. Happo (triangle on map) AM3 is sampled at $700 \mathrm{hPa}$ and filtered for the influence from Asian continental air - more representative of observed baseline conditions in spring.

mately tripled since 1990 (Fig. 1a), and springtime increases $\left(0.5 \mathrm{ppb} \mathrm{yr}^{-1}\right)$ at Taiwan and Mt. Happo that are driven by pollution outflow from the Asian continent. Note that to place the trends derived from the short observational records into a broader context, we show the 20-year trends over 1995 2014 from the model, except for South Korea (1990-2010) and Happo, Japan (1991-2011). We match the time period in the model with observations at these two sites because AM3 shows weaker $\mathrm{O}_{3}$ increases when data for the recent years are included, which likely reflects the offsetting effects of regional emission reductions in South Korea and Japan. 


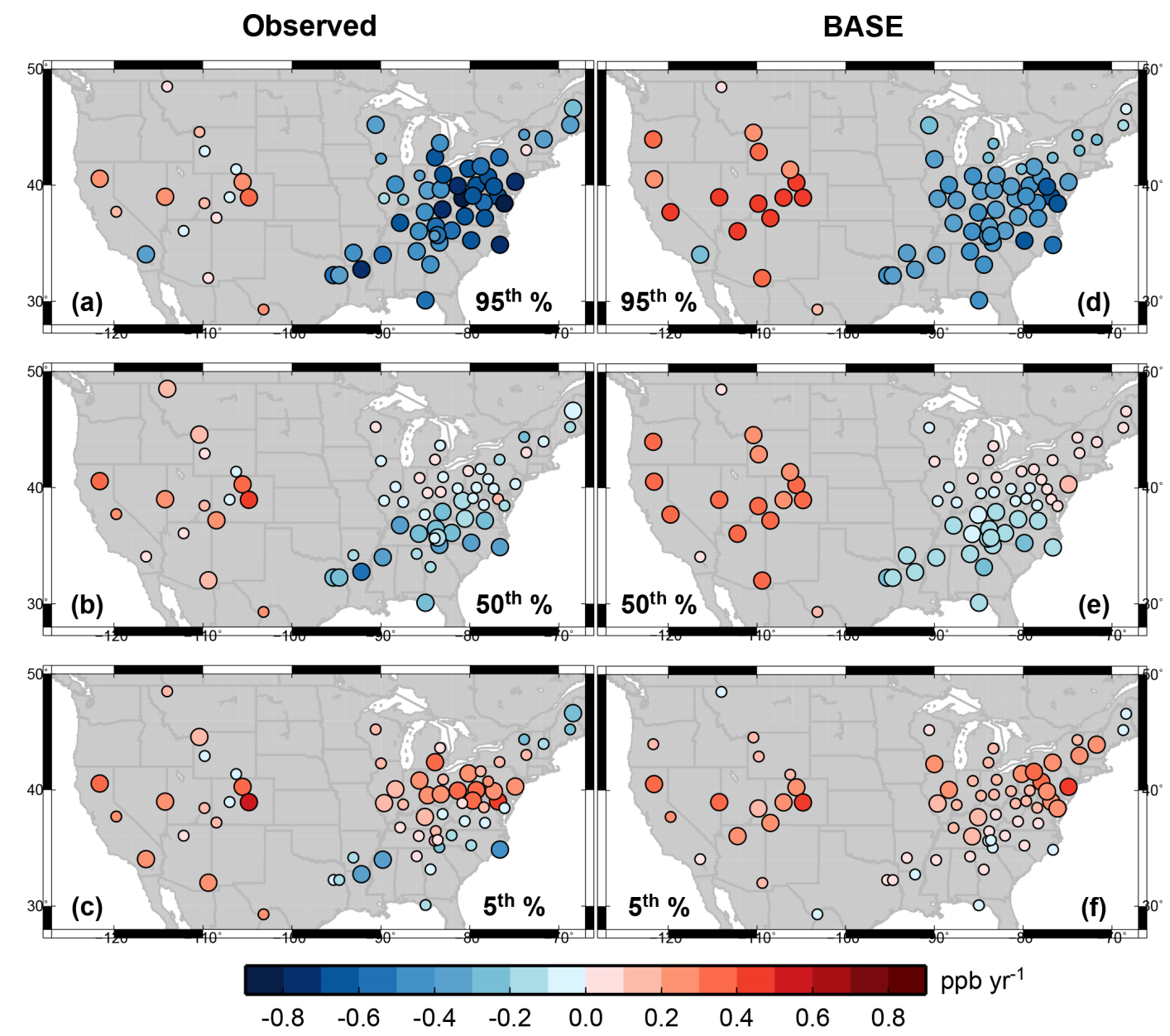

Figure 7. Linear trends in spring (MAM) MDA8 $\mathrm{O}_{3}$ over 1988-2014 at US rural sites for the 95th, 50th, and 5th percentiles as observed (left) and simulated (right) in AM3 BASE. Larger circles indicate sites with statistically significant trends $(p<0.05)$. For WUS high-elevation sites, the model is sampled at $700 \mathrm{hPa}$ and filtered to remove local influence (see text in Sect. 2.4).

Parrish et al. (2014) show that three CMIP5-like models underestimate the observed springtime $\mathrm{O}_{3}$ increase at Mt. Happo by a factor of 4 . This discrepancy may reflect a combination of factors: (1) underestimates of Asian emission growth in the RCP4.5 interpolation after 2000 used in CMIP5 historical simulations (Fig. 1a); (2) trends driven by interannual meteorological variability that free-running CMIP5 models are not expected to reproduce exactly; (3) an excessive offset from Japanese pollution decreases in the models owing to their coarse resolution and limitation in resolving observed baseline conditions at Mt. Happo. Sampling our BASE model at $700 \mathrm{hPa}$ above Happo, we find an $\mathrm{O}_{3}$ increase of $0.35 \pm 0.13 \mathrm{ppb} \mathrm{yr}^{-1}$. When focusing on days strongly influenced by outflow from the East Asian continent (Chinese $\mathrm{COt} \geq 67 \mathrm{th}$ ), the model $\mathrm{O}_{3}$ trend increases to $0.48 \pm 0.13 \mathrm{ppb} \mathrm{yr}^{-1}$, approximating the observed increase of $0.76 \pm 0.35 \mathrm{ppb} \mathrm{yr}^{-1}$ at Mt. Happo (Fig. 6b). The observed and simulated trends are not statistically different given the overlapping confidence limits. The larger confidence limit (uncertainty) derived from the Happo observations reflects the measurement inconsistency before 1998 and instrumental problems after 2007 (Tanimoto et al., 2016). We conclude that GFDL-AM3 captures $65-90 \%$ of the observed $\mathrm{O}_{3}$ increases in Asia, lending confidence in its application to assess the global impacts of rising Asian emissions.

\section{Regional and seasonal variability of US surface $\mathrm{O}_{3}$ trends}

We next focus our analysis on the US, where dense, highfrequency, long-term, reliable measurements of surface $\mathrm{O}_{3}$ facilitate process-oriented model evaluation. Comparisons of surface $\mathrm{O}_{3}$ trends over 1988-2014 at 70 rural monitoring sites across the US as observed and simulated in AM3 BASE are shown in Fig. 7 for spring, Fig. 8 for summer, Fig. 9 for winter, and in Fig. S4 for autumn. The trends are calculated separately for the 5th, 50th and 95th percentiles of the daily MDA8 $\mathrm{O}_{3}$ concentration distribution, with larger circles on 


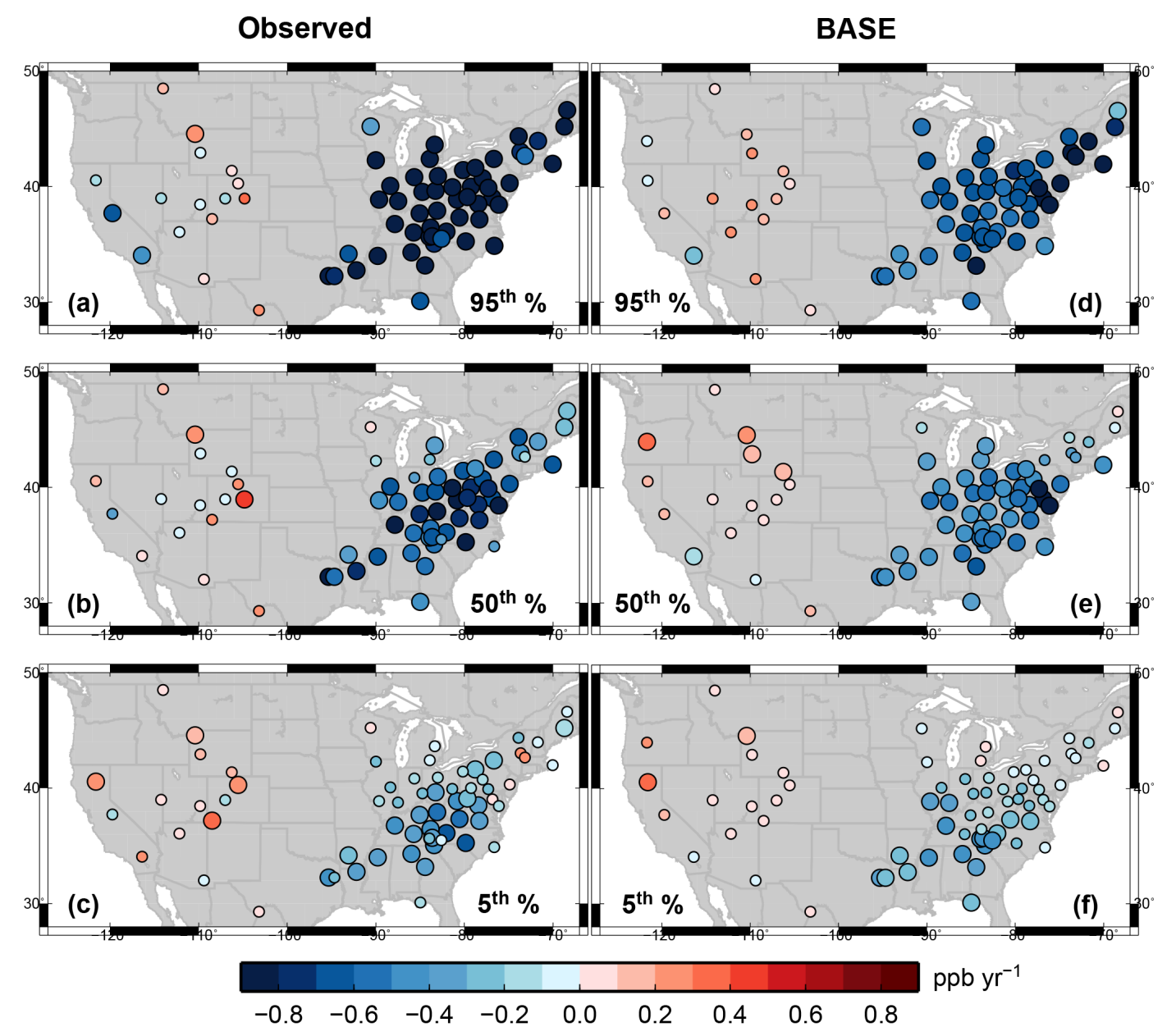

Figure 8. As in Fig. 7, but for summer (JJA). Note that the color scale saturates at \pm 0.8 .

the maps indicating sites with statistically significant trends $(p<0.05)$. We first discuss observations (Sect. 4.1), followed by model evaluation and trend attribution (Sect. 4.2).

\subsection{Observations}

In spring (Fig. 7), observations indicate spatial heterogeneity in $\mathrm{O}_{3}$ trends across the Intermountain West and the northeastern (north of $38^{\circ} \mathrm{N}$ ) and southeastern US. At the 95th percentile (Fig. 7a) the pattern of observed trends is homogeneous across the northeastern and southeastern US, with approximately $85 \%$ of the sites having statistically significant $\mathrm{O}_{3}$ decreases of $0.4-0.8 \mathrm{ppb} \mathrm{yr}^{-1}$ and no sites showing a significant increase. In contrast, significant increases occur at $25 \%$ of the sites in the Intermountain West. Only Joshua Tree National Park located downwind of the Los Angeles Basin shows a significant decrease at the 95 th percentile. At the 50th percentile (Fig. 7b) there are significant $\mathrm{O}_{3}$ decreases of $0.2-0.4 \mathrm{ppb} \mathrm{yr}^{-1}$ in the southeast and little overall change in the northeast, while significant increases of $0.2-0.5 \mathrm{ppb} \mathrm{yr}^{-1}$ occur at $50 \%$ of the sites in the Intermountain West. Significant springtime $\mathrm{O}_{3}$ increases occur at all observed per- centiles at Lassen Volcanic National Park in California, Great Basin National Park in Nevada, Rocky Mountain National Park and US Air Force Academy in Colorado. At the 5th percentile (Fig. 7c) significant $\mathrm{O}_{3}$ increases occur at most sites in the northeast, while little change and some negative trends are found in the southeast. The occurrence of the greatest observed $\mathrm{O}_{3}$ decreases for the highest percentiles is consistent with high-temperature $\mathrm{O}_{3}$ production being more $\mathrm{NO}_{x}$ limited (Pusede et al., 2015) and thus more responsive to decreases in $\mathrm{NO}_{x}$ emissions.

The north-to-south gradient in springtime $\mathrm{O}_{3}$ trends over the EUS reflects the earlier seasonal transition from $\mathrm{NO}_{x}$ saturated to $\mathrm{NO}_{x}$-sensitive $\mathrm{O}_{3}$ production regimes in the southeast, where plentiful radiation in spring enhances $\mathrm{HO}_{x}$ supply and biogenic isoprene emissions begin earlier than in the northeast. The different response of springtime $\mathrm{O}_{3}$ to $\mathrm{NO}_{x}$ controls in the southeast versus northeast noticed in this work is not present in prior analyses for shorter time periods (1990-2010 in Cooper et al., 2012, and 1998-2013 in Simon et al., 2015). We find $72 \%$ of the southeastern sites experiencing significant median $\mathrm{O}_{3}$ decreases in spring over 


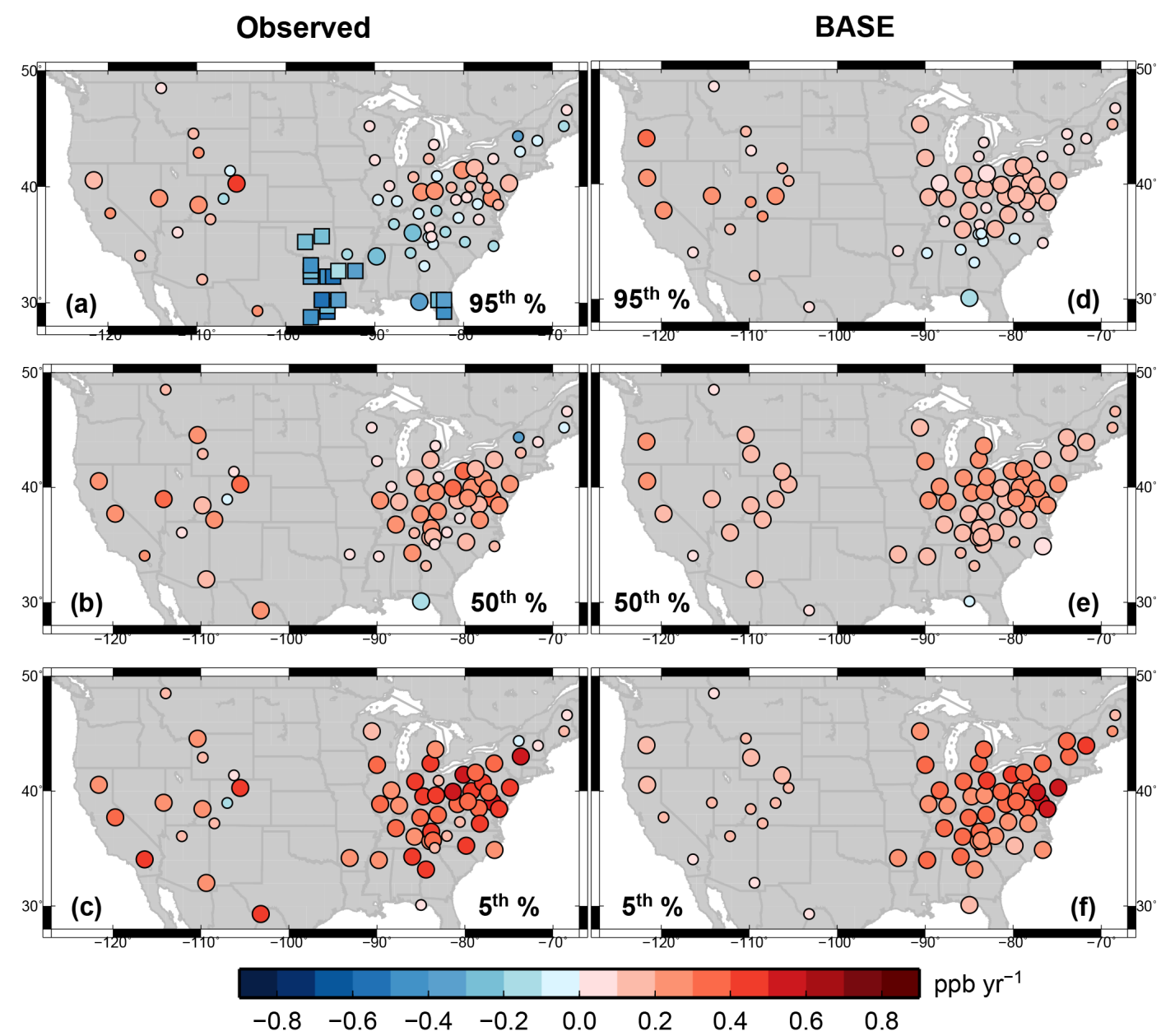

Figure 9. As in Fig. 7, but for winter (DJF). Large squares in (a) denote AQS sites with significant $\mathrm{O}_{3}$ decreases in the 95th percentile.

1988-2014, while Cooper et al. (2012) found only $8 \%$. Sites with significant 95 th percentile springtime $\mathrm{O}_{3}$ decreases in the EUS are also much more common in our study $(85 \%$ versus $43 \%$ in Cooper et al. (2012). In the 5th percentile, $45 \%$ of the northeastern sites in our analysis have significant spring $\mathrm{O}_{3}$ increases, with only $15 \%$ in Cooper et al. (2012) Stronger $\mathrm{O}_{3}$ reductions in the southeast than the northeast also occur during autumn (Fig. S4), reflecting an extension of biogenic isoprene emissions and $\mathrm{NO}_{x}$-sensitive $\mathrm{O}_{3}$ production in the southeast to autumn.

In summer (Fig. 8), as radiation intensifies and isoprene emissions peak seasonally, the $\mathrm{O}_{3}$ production becomes more $\mathrm{NO}_{x}$-limited across both the southeastern and northeastern US, where $\mathrm{NO}_{x}$ emission controls have led to significant $\mathrm{O}_{3}$ decreases of $0.8-1.8 \mathrm{ppb} \mathrm{yr}^{-1}$ in the 95 th percentile and $0.4-0.8 \mathrm{ppb} \mathrm{yr}^{-1}$ in the median value (Fig. 8a-b). In the southeast, significant decreases have also occurred at the lowest percentiles during summer (Fig. 8c), in contrast to the weak response during spring (Fig. 7c). Many northeastern states in the late 1990s and early 2000s did not turn on power plant $\mathrm{NO}_{x}$ emission controls until the $\mathrm{O}_{3}$ season
(May-September), which may contribute to observed differences between spring and summer $\mathrm{O}_{3}$ trends. Compared to the 1990-2010 trends reported in Cooper et al. (2012), the EUS summer $\mathrm{O}_{3}$ decreases reported here with additional data to 2014 are $33 \%$ stronger. Despite reductions in precursor emissions in the WUS cities (Fig. 1d), there are no significant summer $\mathrm{O}_{3}$ decreases at the intermountain sites, except in Yosemite and Joshua Tree national parks for the 95th percentile. Instead, a significant summer increase of $\sim 0.3 \mathrm{ppb} \mathrm{yr}^{-1}$ occurs across the entire $\mathrm{O}_{3}$ distribution at Yellowstone. Significant summer increases are found in the 5th percentile for Lassen, Mesa Verde, and Rocky Mountain national parks.

In winter (Fig. 9), observed $\mathrm{O}_{3}$ increases are more common than in spring and summer across the US. The wintertime $\mathrm{O}_{3}$ increases are strongest in the lowest percentiles over the EUS, indicating the influence from weakened $\mathrm{NO}_{x}$ titration as a result of regional $\mathrm{NO}_{x}$ emission controls (see also Gao et al., 2013; Clifton et al., 2014; Simon et al., 2015). Even during winter, some decreasing $\mathrm{O}_{3}$ trends are found in the highest percentiles over the southeast (Fig. 9a), 
most prominently in Texas (Dallas and Houston), where tropical climate and year-round active photochemistry makes $\mathrm{O}_{3}$ most responsive to regional $\mathrm{NO}_{x}$ emission controls. Despite the greatest $\mathrm{NO}_{x}$ emission reductions over the past decade in the central and northeastern US regions, observed $\mathrm{O}_{3}$ reductions have been most pronounced in the southeast, particularly in spring and autumn.

\subsection{Model evaluation and attribution of observed $\mathrm{O}_{3}$ trends}

The BASE simulation with GFDL-AM3 captures the salient features of observed $\mathrm{O}_{3}$ trends over 1988-2014 at rural sites across the US: (1) the overall springtime increases and the lack of significant trends in summer over the Intermountain West; (2) the north-to-south gradients in $\mathrm{O}_{3}$ trends during spring and the largest decreases in the 95th percentile during summer over the EUS; (3) wintertime increases in the 5th and 50th percentiles (left versus right panels in Figs. 7 to 9). AM3 also simulates a median springtime $\mathrm{O}_{3}$ increase of $0.32 \pm 0.11 \mathrm{ppb} \mathrm{yr}^{-1}$ over $1988-2014\left(0.64 \pm 0.50 \mathrm{ppb} \mathrm{yr}^{-1}\right.$ over 2004-2014) at Mount Bachelor Observatory in Oregon, consistent with the positive trend $\left(0.63 \pm 0.41 \mathrm{ppb} \mathrm{yr}^{-1}\right)$ observed over the shorter 2004-2015 period (Gratz et al., 2014). These analyses imply that GFDL-AM3 represents the underlying chemical and physical processes controlling the response of US surface $\mathrm{O}_{3}$ means and extremes to changes in global-to-regional precursor emissions and climate, despite mean state biases (Figs. S5-S6).

The filtered model shows greater 95th percentile $\mathrm{O}_{3}$ increases than observed at some WUS sites (e.g., Yosemite; Grand Canyon; Canyonlands) for both spring and summer (Figs. 7a, d and 8a, d), reflecting that observations at these sites sometimes can be influenced by transport of photochemically aged plumes from nearby urban areas and from southern California during late spring and summer. When sampled at the surface, AM3 simulates small summertime $\mathrm{O}_{3}$ decreases in the 95th and 50th percentiles over the Intermountain West (Fig. 4b, d), consistent with observations at Yosemite, Grand Canyon, and Canyonlands (Fig. 8a, b). As illustrated in Fig. 3 for spring and discussed in Sect. 2.4, individual sites in the west display observed trends falling in between the filtered model and those sampled at the surface versus aloft.

We examine how US surface $\mathrm{O}_{3}$ responds to changes in regional anthropogenic emissions, hemispheric background, and meteorology by comparing $\mathrm{O}_{3}$ trends in the BASE, Background, and FIXEMIS experiments (Figs. 10-11). With North American anthropogenic emissions shut off in the Background simulation, little difference is discernable from the BASE simulation for WUS $\mathrm{O}_{3}$ trends during spring (first versus second rows in Fig. 10), indicating the key role of hemispheric background driving increases in springtime $\mathrm{O}_{3}$ over the WUS. With anthropogenic emissions held constant in time, FIXEMIS still shows statistically significant spring $\mathrm{O}_{3}$ increases in the 95th percentile (Fig. 10c), approximately half of the trends simulated in BASE, for Grand Canyon, Canyonlands, Mesa Verde and Rocky Mountain national parks. Prior work shows that deep stratospheric intrusions contribute to the highest observed and simulated surface $\mathrm{O}_{3}$ events at these sites (Langford et al., 2009; Lin et al., 2012a). Strong year-to-year variability of such intrusion events (Lin et al., 2015a) can confound the attribution of springtime $\mathrm{O}_{3}$ changes over the WUS to anthropogenic emission trends, particularly in the highest percentile and over a short record length. Summer avoids this confounding influence when stratospheric intrusions are at their seasonal minimum, as evidenced by little $\mathrm{O}_{3}$ change in FIXEMIS over the WUS (Fig. 11c, f). In contrast to spring, the model shows larger differences in WUS $\mathrm{O}_{3}$ trends between BASE and Background for summer when North American pollution peaks seasonally (Fig. 10a, d versus b, e compared to Fig. 11a, d versus b, e). There are significant increases of 0.2 $0.5 \mathrm{ppb} \mathrm{yr}^{-1}$ in the 95 th and 50th percentile summer background $\mathrm{O}_{3}$ at more than $50 \%$ of the western sites (Fig. 11b, e), offsetting the $\mathrm{O}_{3}$ decreases resulting from $\mathrm{US} \mathrm{NO}_{x}$ reductions and leading to little overall change in total observed and simulated $\mathrm{O}_{3}$ at WUS rural sites during summer (Fig. 8).

Over the EUS, AM3 also simulates background $\mathrm{O}_{3}$ increases, occurring in both the 95th and 50th percentiles, with a rate of $0.1-0.3 \mathrm{ppbyr}^{-1}$ during spring (Fig. 10b, e) and $0.2-0.5$ ppb yr $^{-1}$ during summer (Fig. $11 \mathrm{~b}, \mathrm{e}$ ). Based on prior model estimates that springtime background $\mathrm{O}_{3}$ is greater in the northeast than the southeast (Lin et al., 2012a, b; Fiore et al., 2014), one might assume that the springtime $\mathrm{O}_{3}$ increases in the 5th percentile observed over the northeast (Fig. 7c) have been influenced by a rising background. However, AM3 simulates homogeneous background $\mathrm{O}_{3}$ trends across the entire EUS (Fig. 10b, e), indicating that the observed north-tosouth gradient in $\mathrm{O}_{3}$ trends reflects an earlier seasonal onset of $\mathrm{NO}_{x}$-sensitive photochemistry in the southeast, as opposed to the background influence.

A warming climate is most likely to worsen the highest $\mathrm{O}_{3}$ events in polluted regions (e.g., Schnell et al., 2016; Shen et al., 2016). With anthropogenic emissions held constant in time over 1988-2014, FIXEMIS suggests significant increases of $0.2-0.4 \mathrm{ppb} \mathrm{yr}^{-1}$ in the 95 th percentile summertime $\mathrm{O}_{3}$ over the EUS (Fig. 11c). Using self-organizing map cluster analysis, Horton et al. (2015) identified robust increases in the occurrence of summer anticyclonic circulations over eastern North America since 1990. We find that biogenic isoprene emissions over this period increased significantly by $1-2 \% \mathrm{yr}^{-1}$ (10 to $20 \mathrm{mg} \mathrm{C} \mathrm{m}^{-2}$ summer $^{-1}$ ) throughout the EUS in the model, consistent with simulated increases in the 90th percentile JJA daily maximum temperature (Fig. 12a-b). Increases in isoprene emissions contribute to raising EUS background $\mathrm{O}_{3}$ in summer (Fig. 11b, e). Using the Global Land-Based Datasets for Monitoring Climate Extremes (GHCNDEX; Donat et al., 2013), we find increases in the number of warm days above the 90th percentile and 
BASE

BASE
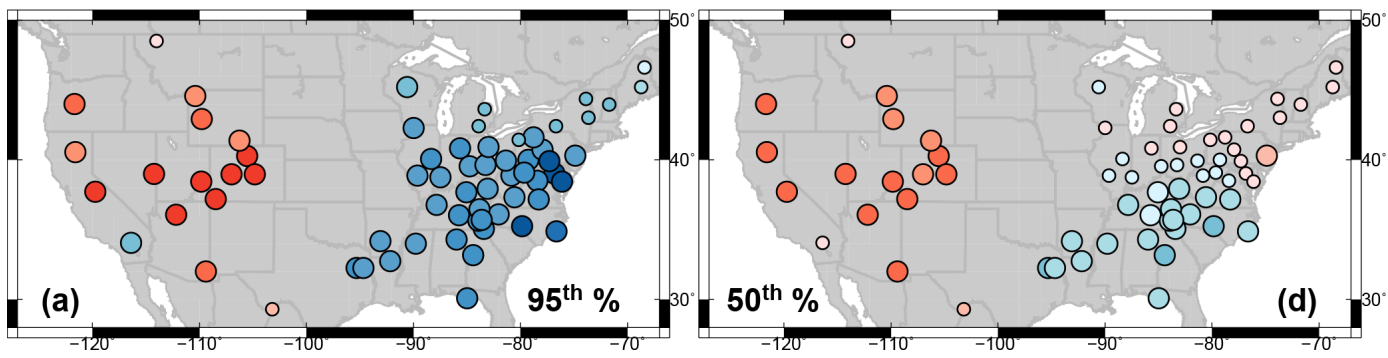

Background

Background

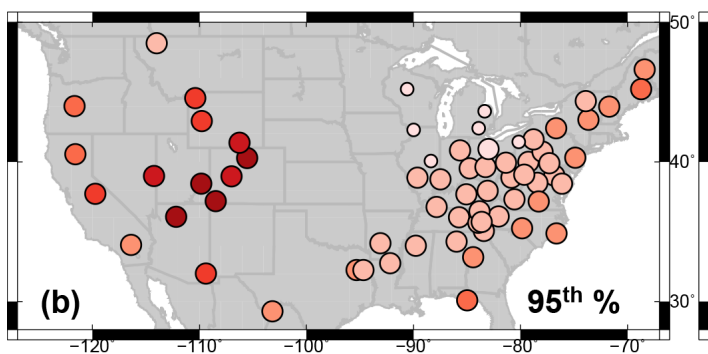

FIXEMIS

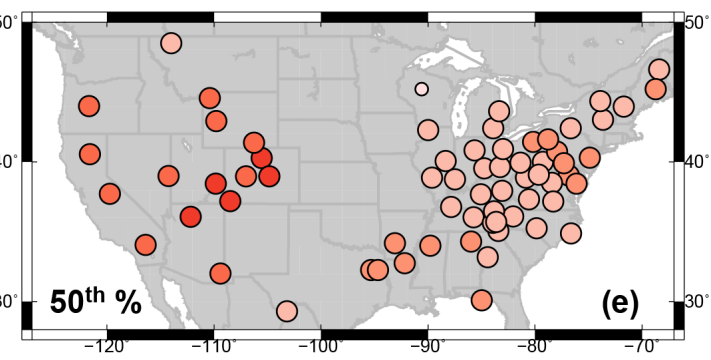

FIXEMIS

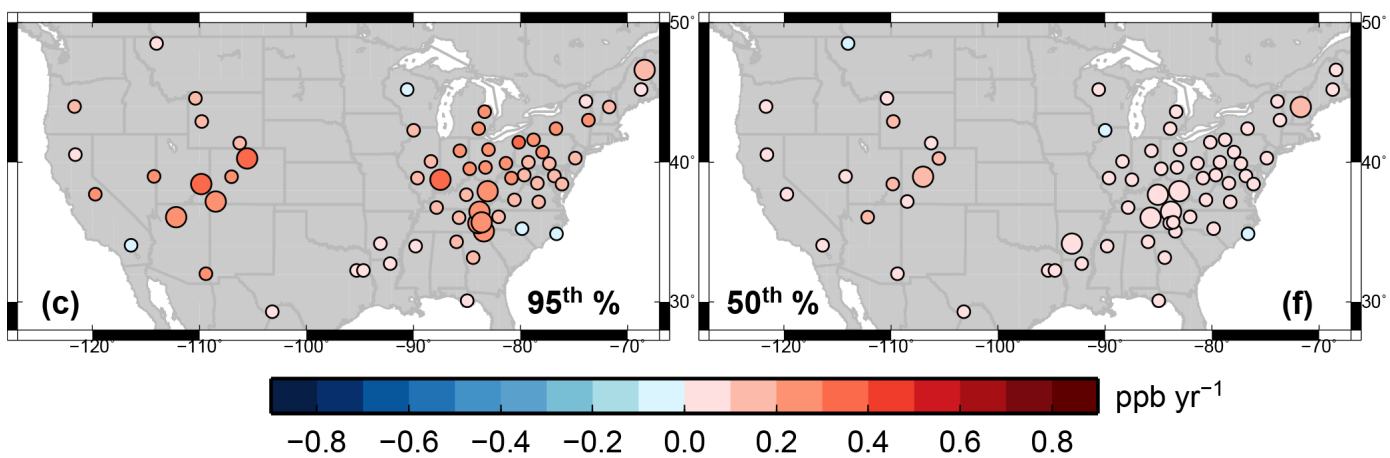

Figure 10. Linear trends in the 95th (left) and 50th (right) percentile springtime MDA8 $\mathrm{O}_{3}$ over 1988-2014 at US rural sites from BASE (top), Background (middle) and FIXEMIS simulations (bottom). Larger circles indicate sites with statistically significant trends $(p<0.05)$. Top panels are repeated from Fig. 7d, e. Note that the 95th (50th) percentile is sampled separately from the Background and FIXEMIS simulations without depending on the times when the BASE simulation is experiencing the 95 th (50th) percentile days.

maximum temperature over the southeastern US in August (Fig. 12c-d). The trends in temperature extremes are similar between June and August, but there is no significant trend in July (not shown). While changes in regional temperature extremes on 20- to 30-year time series may reflect internal climate variability (Shepherd, 2015), we suggest that increasing hot extremes and biogenic isoprene emissions over the last 2 decades may have offset some of the benefits of regional $\mathrm{NO}_{x}$ reductions in the EUS.

\section{Impacts of rising Asian emissions, methane and wildfires on western US $\mathrm{O}_{3}$}

\subsection{Historical western $\mathrm{US} \mathrm{O}_{3}$ trends in spring}

Further indications of the factors driving baseline $\mathrm{O}_{3}$ changes over the WUS can be inferred by examining the time series at several high-elevation sites, which most frequently sample baseline $\mathrm{O}_{3}$ in the free troposphere during spring (Sect. 2.4). Figure 13 shows the results, both observed and simulated, for six such monitoring sites: Great Basin National Park in Nevada (2.1 km a.s.l.), Rocky Mountain National Park (2.7 kma.s.1.) in Colorado, US Air Force Academy (1.9 km a.s.1.) in Colorado Springs, Yellowstone National Park (2.4 km a.s.l.) and Pinedale (2.4 km a.s.l.) in Wyoming, and Mesa Verde National Park (2.2 kma.s.l.) in the Colorado-New Mexico-Arizona-Utah four-corner 


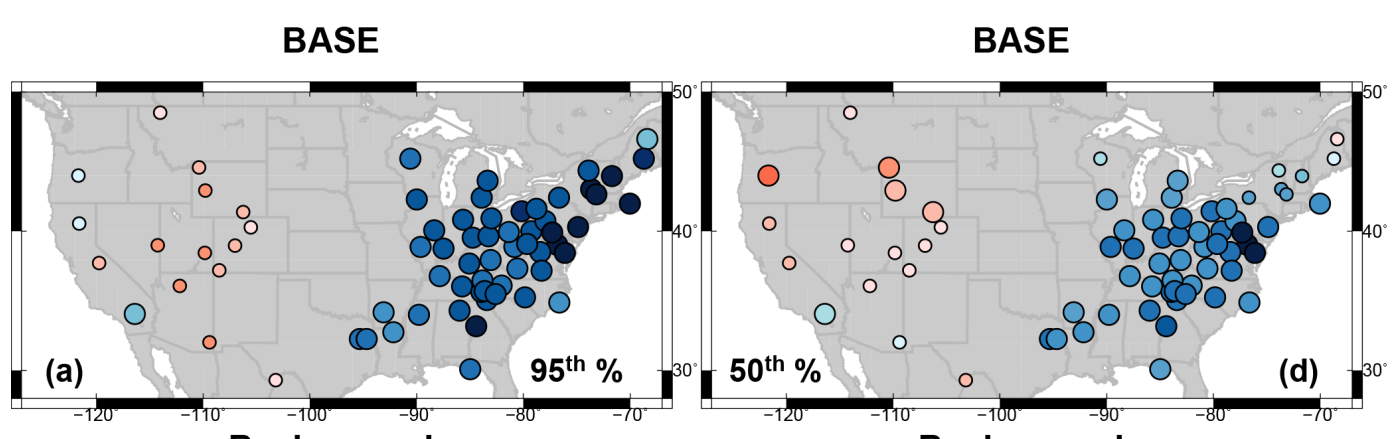

Background

Background

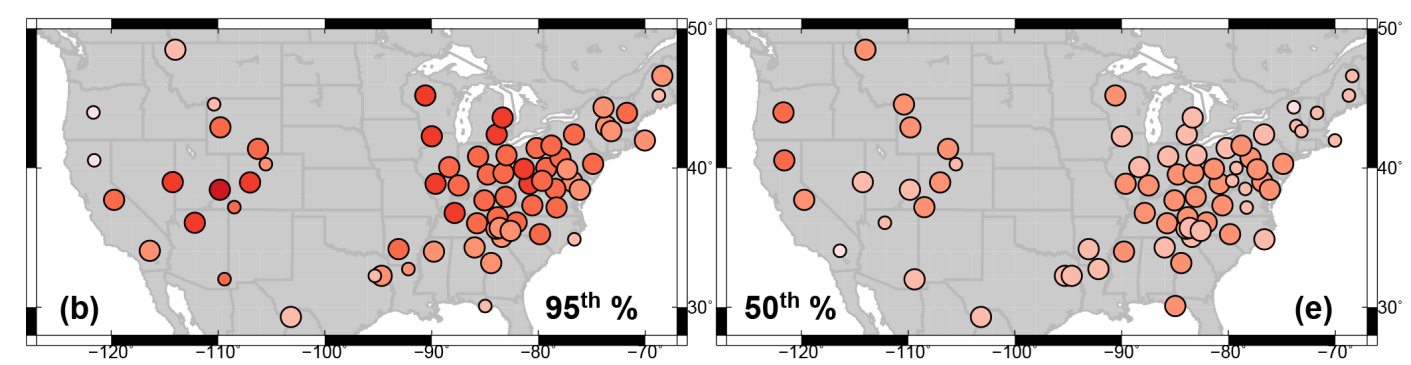

FIXEMIS

FIXEMIS

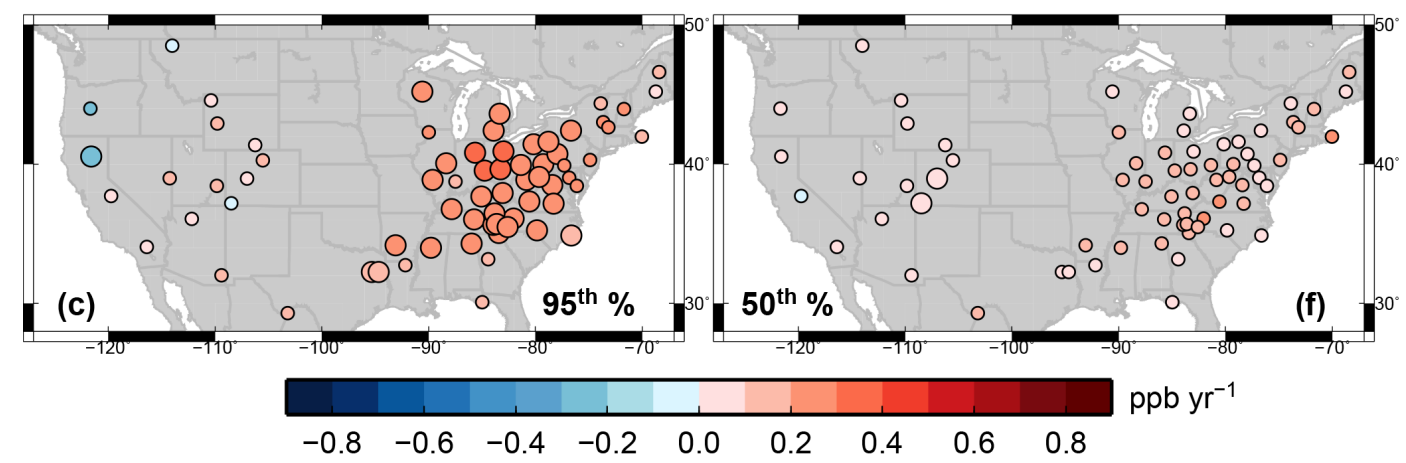

Figure 11. As in Fig. 10, but for summer. Top panels are repeated from Fig. 8d, e.

region. The observed median values of springtime MDA8 $\mathrm{O}_{3}$ have increased significantly at a rate of $0.2-0.5 \mathrm{ppb} \mathrm{yr}^{-1}$ over the past 20-27 years at these sites, except Pinedale, where the increase in background $\mathrm{O}_{3}$ is likely offset by the $\mathrm{O}_{3}$ decrease due to recent emission control for the large oil and gas production fields in this area (http://deq.wyoming. gov/aqd/winter-ozone/resources/technical-documents/).

When filtered to remove the influence from fresh local pollution (Sect. 2.4), AM3 BASE captures the long-term trends of $\mathrm{O}_{3}$ observed at these sites.

Correlating AM3 Background with observed $\mathrm{O}_{3}$ indicates that most of the observed variability reflects changes in the background, with fluctuations in stratospheric influence contributing to anomalies on interannual timescales (e.g., the 1999 anomaly, Lin et al., 2015a), whereas Asian influence dominates the decadal trends as discussed below. The $\mathrm{O}_{3}$ reduction resulting from US anthropogenic emission controls is less than $0.1 \mathrm{ppb} \mathrm{yr}^{-1}$ (BASE minus Background) at these baseline sites. We show model results for the entire 1980-
2014 period for Great Basin, Rocky Mountain, and the US Air Force Academy to provide context for observed trends in the 2 most recent decades (Fig. 13a). In the 1980s when Chinese $\mathrm{NO}_{x}$ emissions $\left(\sim 4 \mathrm{Tg} \mathrm{yr}^{-1} \mathrm{NO}\right)$ were much lower than US NO$x$ emissions ( $\sim 15 \mathrm{Tg} \mathrm{yr}^{-1} \mathrm{NO}$ ) (Granier et al., 2011), there was little overall $\mathrm{O}_{3}$ change over the WUS in the model. From the mid-1990s onwards, with $\mathrm{NO}_{x}$ emissions in China rising steeply (Fig. 1a) and surpassing US emissions in the 2000s, the $\mathrm{O}_{3}$ trends at remote WUS sites appear to be dominated by trends of background, reflecting rising emissions outside the US. The largest spring $\mathrm{O}_{3}$ increases from 19811990 to 2003-2012 at $700 \mathrm{hPa}$ extend from Southeast Asia to the subtropical North Pacific Ocean to the southwestern US (Fig. S7a), consistent with the influence of rising Asian precursor emissions.

Table 2 contains a summary of the drivers of $\mathrm{O}_{3}$ trends in the model at seven CASTNet sites that exhibit a significant spring $\mathrm{O}_{3}$ increase observed over 1988-2012. Here we focus our attribution analysis on the period 1988-2012 (in- 

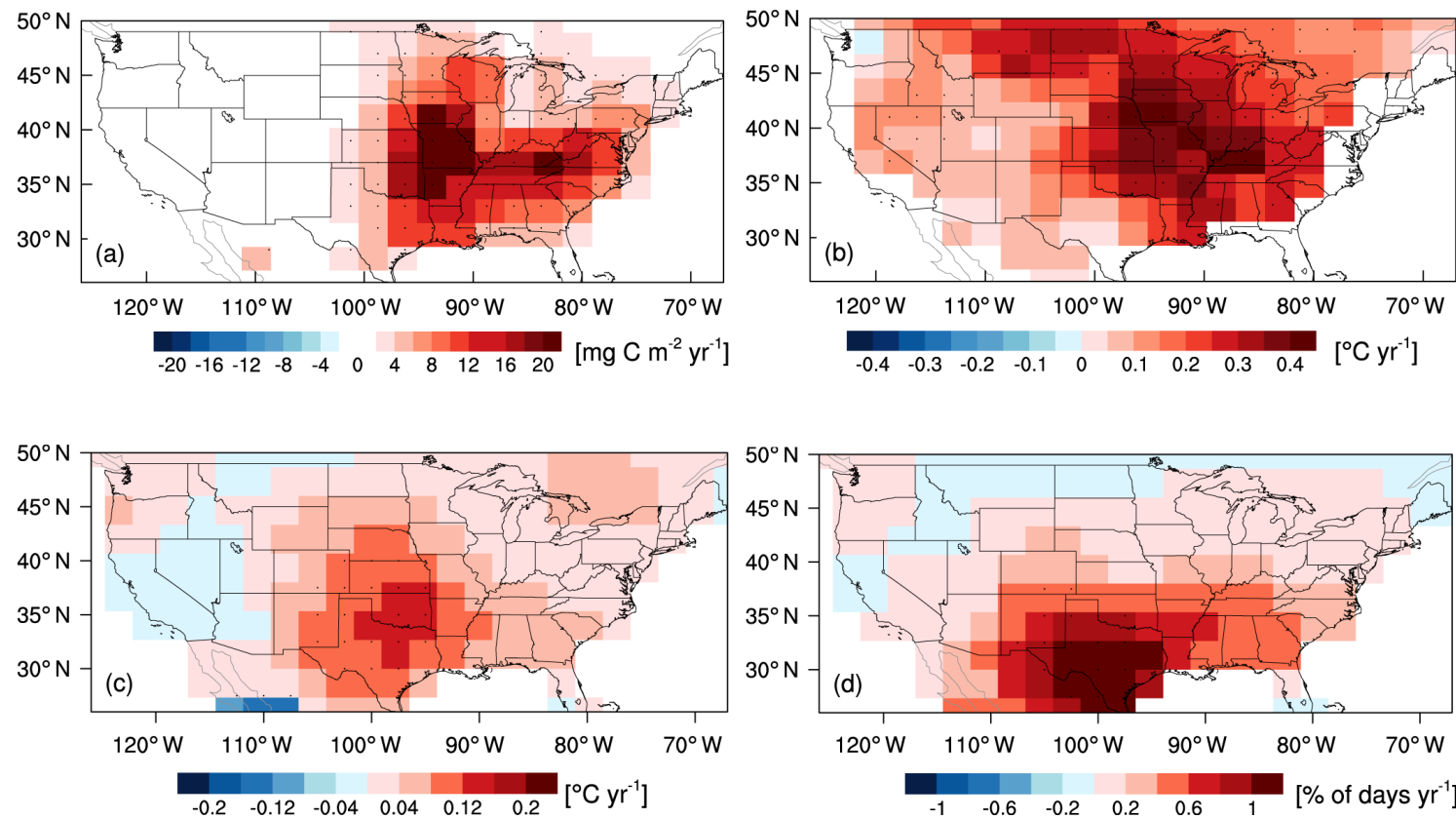

Figure 12. The 1990-2012 trends in (a) model JJA total biogenic isoprene emissions, (b) model 90th percentile JJA daily maximum temperature, (c) the warmest daily maximum temperature and (d) the frequency of warm days (i.e., those above the 90 th percentile for the base period 1961-1990) for August obtained from the GHCNDEX dataset (Donat et al., 2013; available at http://www.climdex.org/viewdownload.html). Stippling denotes areas where the change is statistically significant $(p<0.05)$. Note that the trends are calculated for the 1990-2012 period, instead of 1988-2014, to avoid the influence from hot extremes in 1988 and cold conditions in 2014 (Sect. 6). When these years are included, the trends in (c) and (d) are swamped by the anomalies. The trends in (a) and (b) are similar between 1990-2012 and 1988-2014.

Table 2. Summary of springtime median MDA8 $\mathrm{O}_{3}$ trends (in $\mathrm{ppb} \mathrm{yr}^{-1}$ ) over 1988-2012 at WUS sites from observations and AM3 simulations. Trends with the $95 \%$ confidence intervals and levels of significance (bold: $<1 \%$; italic: $1-5 \%$; plain: $\geq 5 \%$ ) were estimated by the two-tailed $t$ test.

\begin{tabular}{lrrrrrrr}
\hline Experiment & Lassen & Great Basin & Rocky Mountain & Mesa Verde & Yellowstone & Yosemite & Chiricahua \\
\hline Observed & $\mathbf{0 . 3 8} \pm \mathbf{0 . 1 4}$ & $\mathbf{0 . 3 8} \pm \mathbf{0 . 2 6}$ & $\mathbf{0 . 3 7} \pm \mathbf{0 . 1 8}$ & $\mathbf{0 . 3 0} \pm \mathbf{0 . 1 8}$ & $0.21 \pm 0.19$ & $0.37 \pm 0.32$ & $\mathbf{0 . 1 7} \pm \mathbf{0 . 1 0}$ \\
BASE* & $\mathbf{0 . 3 3} \pm \mathbf{0 . 1 1}$ & $\mathbf{0 . 3 4} \pm \mathbf{0 . 1 2}$ & $\mathbf{0 . 3 2} \pm \mathbf{0 . 1 3}$ & $\mathbf{0 . 3 7} \pm \mathbf{0 . 1 4}$ & $\mathbf{0 . 2 1} \pm \mathbf{0 . 1 1}$ & $\mathbf{0 . 3 5} \pm \mathbf{0 . 1 7}$ & $0.25 \pm 0.19$ \\
Background & $\mathbf{0 . 3 1} \pm \mathbf{0 . 1 2}$ & $\mathbf{0 . 4 0} \pm \mathbf{0 . 1 3}$ & $\mathbf{0 . 4 5} \pm \mathbf{0 . 1 3}$ & $\mathbf{0 . 4 3} \pm \mathbf{0 . 1 7}$ & $\mathbf{0 . 3 0} \pm \mathbf{0 . 1 1}$ & $\mathbf{0 . 4 1} \pm \mathbf{0 . 1 6}$ & $\mathbf{0 . 3 2} \pm \mathbf{0 . 2 1}$ \\
Background $_{\text {EA }}$ & $\mathbf{0 . 4 1} \pm \mathbf{0 . 1 2}$ & $\mathbf{0 . 3 9} \pm \mathbf{0 . 1 8}$ & $\mathbf{0 . 5 0} \pm \mathbf{0 . 1 5}$ & $\mathbf{0 . 5 2} \pm \mathbf{0 . 2 0}$ & $\mathbf{0 . 4 0} \pm \mathbf{0 . 1 6}$ & $\mathbf{0 . 4 7} \pm \mathbf{0 . 1 7}$ & $\mathbf{0 . 4 7} \pm \mathbf{0 . 2 1}$ \\
IAVASIA $^{*}$ & $\mathbf{0 . 2 9} \pm \mathbf{0 . 1 3}$ & $\mathbf{0 . 3 1} \pm \mathbf{0 . 1 1}$ & $\mathbf{0 . 2 5} \pm \mathbf{0 . 1 1}$ & $\mathbf{0 . 2 7} \pm \mathbf{0 . 1 1}$ & $\mathbf{0 . 1 9} \pm \mathbf{0 . 1 1}$ & $\mathbf{0 . 2 4} \pm \mathbf{0 . 1 4}$ & $0.15 \pm 0.15$ \\
IAVASIA $_{\text {EA }}$ & $\mathbf{0 . 2 6} \pm \mathbf{0 . 1 6}$ & $\mathbf{0 . 2 6} \pm \mathbf{0 . 1 6}$ & $\mathbf{0 . 3 5} \pm \mathbf{0 . 1 3}$ & $\mathbf{0 . 3 2} \pm \mathbf{0 . 1 3}$ & $\mathbf{0 . 2 7} \pm \mathbf{0 . 1 6}$ & $\mathbf{0 . 3 1} \pm \mathbf{0 . 1 8}$ & $\mathbf{0 . 2 5} \pm \mathbf{0 . 1 5}$ \\
IAVCH $_{4}^{*}$ & $0.18 \pm 0.12$ & $\mathbf{0 . 2 0} \pm \mathbf{0 . 1 1}$ & $0.12 \pm 0.09$ & $0.16 \pm 0.12$ & $0.09 \pm 0.12$ & $0.15 \pm 0.16$ & $0.04 \pm 0.15$ \\
IAVFIRE $_{\text {FIXEMIS }}$ & $0.10 \pm 0.12$ & $0.14 \pm 0.12$ & $0.17 \pm 0.14$ & $0.16 \pm 0.14$ & $0.11 \pm 0.13$ & $0.15 \pm 0.16$ & $0.08 \pm 0.17$ \\
O $_{3}$ Strat & $0.08 \pm 0.12$ & $0.12 \pm 0.12$ & $0.16 \pm 0.12$ & $0.13 \pm 0.12$ & $0.09 \pm 0.13$ & $0.12 \pm 0.16$ & $0.04 \pm 0.16$ \\
\hline
\end{tabular}

The ${ }^{*}$ mask indicates data filtered to represent baseline conditions (NACOt $\leq 67$ th). The EA subscript indicates that data were filtered to represent transport conditions favoring the import of Asian pollution (EACOt $\geq 67$ th).

stead of 1988-2014) because the IAVASIA and $\mathrm{IAVCH}_{4}$ simulations only extend to 2012. Meteorology varies from year to year in all experiments. Thus, we quantify the contributions of rising Asian emissions in IAVASIA, global methane in $\mathrm{IAVCH}_{4}$, and wildfire emissions in IAVFIRE by subtracting out the slope of the linear regression of seasonal $\mathrm{O}_{3}$ means in FIXEMIS. Simulated $\mathrm{O}_{3}$ with anthropogenic emissions varying in both South and East Asia but held constant elsewhere shows statistically significant increases of 0.1 $0.2 \mathrm{ppb} \mathrm{yr}^{-1}$ ( $p \leq 0.01$; IAVASIA minus FIXEMIS in Table 2), consistent with trends of $0.2 \mathrm{ppb} \mathrm{yr}^{-1}$ estimated by scaling results from HTAP phase 1 multi-model sensitivity experiments with Asian emissions reduced by $20 \%$ (Reidmiller et al., 2009). This Asian influence can explain 50$65 \%$ of the modeled background $\mathrm{O}_{3}$ increase in spring (Table 2). 

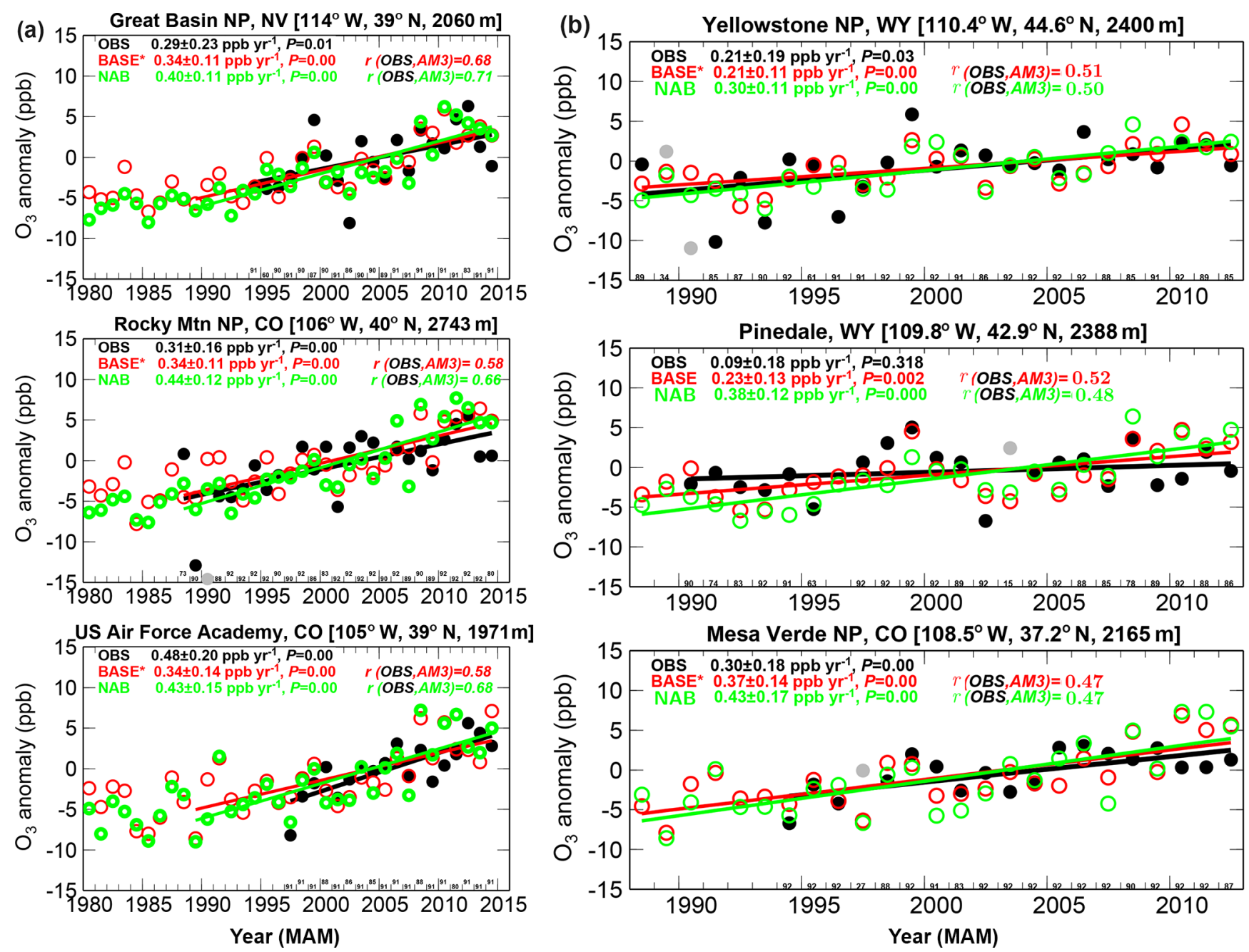

Figure 13. (a) Time series of median spring MDA8 $\mathrm{O}_{3}$ anomalies (relative to the 1995-2014 mean) at Great Basin, Rocky Mountain, and US Air Force Academy as observed (black) and simulated in AM3 BASE filtered for baseline conditions (red; see Sect. 2.4) and in Background with North American anthropogenic emissions zeroed out (NAB; green). Presented at the top of the graph are statistics from the linear fit and correlations between observations and simulations. Numbers at the bottom of the graph denote the sample size of observations for each year. Gray dots indicate uncertain observations that are removed from the linear fit (see Sect. 2.3).(b) Same as Fig. 13a, but for Yellowstone, Pinedale, and Mesa Verde over the period 1988-2012.

With only methane varying, the model trends are less than $0.1 \mathrm{ppb} \mathrm{yr}^{-1}$ (IAVCH 4 minus FIXEMIS), accounting for an average of $15 \%$ of the background increase. The contribution from wildfire emissions during spring is of minor importance (IAVFIRE minus FIXEMIS, Table 2). A stratospheric $\mathrm{O}_{3}$ tracer $\left(\mathrm{O}_{3}\right.$ Strat $)$ in AM3 (Lin et al., 2012a, 2015a) demonstrates a positive but insignificant trend in stratospheric $\mathrm{O}_{3}$ transport to the sites. We examine the trends of lower tropospheric $\mathrm{O}_{3}$ at these sites when transport conditions favor the import of Asian pollution into western North America, as diagnosed by the East Asian CO tracer (EACOt) exceeding the 67th percentile for each spring. Similar to the conclusion of Lin et al. (2015b), we find that the rate of $\mathrm{O}_{3}$ increase in the Background simulation is greater by $0.05-0.1 \mathrm{ppb} \mathrm{yr}^{-1}$ under strong transport from Asia than without filtering. Filter- ing the IAVASIA simulation for Asian influence also results in greater $\mathrm{O}_{3}$ increases than filtering for baseline conditions (Table 2).

Rising Asian emissions even influence trends of $\mathrm{O}_{3}$ downwind of the Los Angeles Basin during spring. $\mathrm{O}_{3}$ measured in Joshua Tree National Park shows an increase of $0.31 \pm 0.25 \mathrm{ppb} \mathrm{yr}^{-1}$ in spring over 1990-2010 (Cooper et al., 2012), despite significant improvements in $\mathrm{O}_{3}$ air quality in the Los Angeles Basin (Warneke et al., 2012). The $\mathrm{O}_{3}$ record extended to 2014 shows a decline in the 95th percentile $\mathrm{O}_{3}$ in Joshua Tree National Park for both spring and summer (Figs. 7-8), whereas the 5th percentile continues to increase in spring and there is no significant trend in the median. Sampling the AM3 Background simulation at this site indicates a rising background $\left(0.31 \pm 0.14 \mathrm{ppb} \mathrm{yr}^{-1}\right)$. Air- 


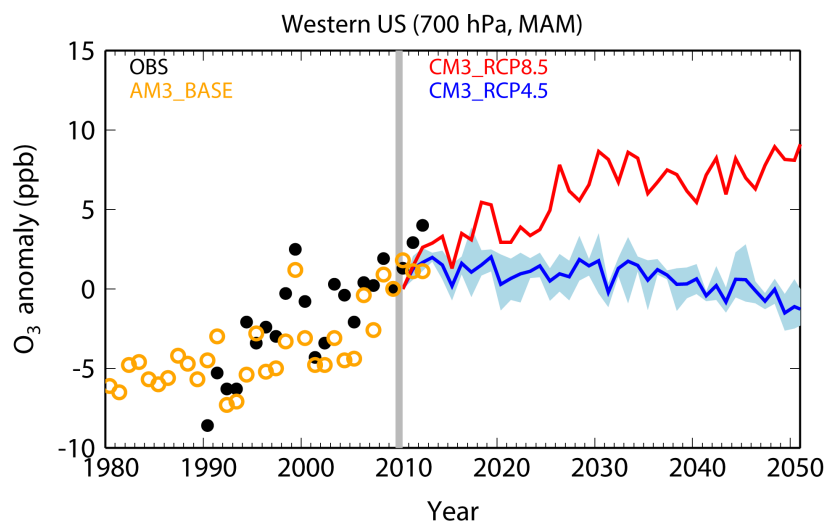

Figure 14. Future projections. Time series of median springtime $\mathrm{O}_{3}$ changes relative to 2010 in GFDL AM3 hindcast (orange circles) and CM3 future simulations for RCP8.5 (red) versus RCP4.5 (blue; shading represents the range of three ensemble members), sampled at $700 \mathrm{hPa}$ over the WUS $\left(35-45^{\circ} \mathrm{N}, 120-105^{\circ} \mathrm{W}\right)$. Black circles indicate observed changes averaged from the Lassen, Great Basin, and Rocky Mountain national parks.

craft measurements in May-June 2010 indicate the presence of Asian pollution layers $2 \mathrm{~km}$ above southern California with distinct sulfate enhancements coincident with low organic mass (Lin et al., 2012b), supporting the conclusion that rising Asian emissions can contribute to trends of $\mathrm{O}_{3}$ observed in this region. Yosemite National Park (1.6 km a.s.l.) and Chiricahua National Monument (1.5 km a.s.l.) are also influenced by increases in Asian emissions and concurrent decreases in local pollution in California. $\mathrm{O}_{3}$ observed at Yosemite shows an increase from 1995 to around 2012 $\left(0.37 \pm 0.32 \mathrm{ppb} \mathrm{yr}^{-1}\right.$; Fig. S8), which the model attributes primarily to rising Asian emissions (Table 2), but observations have remained constant since then, reflecting an offset by $\mathrm{O}_{3}$ decreases in California (Fig. 4).

\subsection{Projecting western US springtime $\mathrm{O}_{3}$ for the 21st Century}

Under the RCP8.5 scenario, Chinese $\mathrm{NO}_{x}$ emissions are projected to peak in 2020-2030, reflecting an increase of $\sim 50 \%$ from 2010 (Fig. 1a), followed by a sharp decrease, reaching 1990 levels by 2050. Global methane increases by $\sim 60 \%$ from 2010 to 2050 under RCP8.5 (Fig. S1). Under the RCP4.5 scenario, in contrast, $\mathrm{NO}_{x}$ emissions in China change little over 2010-2030 and global methane remains almost constant from 2010 to $2050 . \mathrm{NO}_{x}$ emissions in the US decrease through 2050 under both scenarios, by $\sim 40 \%$ from 2010. A number of studies have examined future US $\mathrm{O}_{3}$ changes under the RCPs (e.g., Gao et al., 2013; Clifton et al., 2014; Pfister et al., 2014; Fiore et al., 2015; Barnes et al., 2016). However, as discussed earlier, the trends of $\mathrm{O}_{3}$ in the model when sampled near the surface are overwhelmingly dominated by US anthropogenic emission trends. Thus,
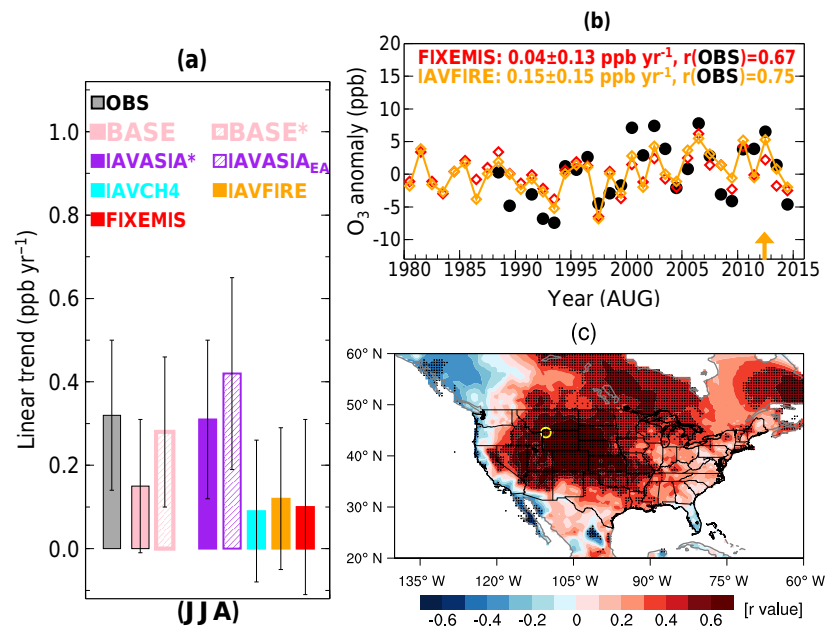

Figure 15. Summertime $\mathrm{O}_{3}$ in Yellowstone National Park. (a) Median JJA MDA8 $\mathrm{O}_{3}$ trends over 1988-2012 at Yellowstone from observations (black) and simulations sampled at $700 \mathrm{hPa}$ for BASE without filtering (pink), BASE filtered for baseline conditions (hatched pink), IAVASIA (solid purple, baseline), IAVASIA filtered for Asian influence (EACOt $\geq 67$ th, hatched purple), IAVCH4 (cyan), IAVFIRE (orange) and FIXEMIS (red). (b) Time series of anomalies in August median $\mathrm{MDA} 8 \mathrm{O}_{3}$ at Yellowstone as observed (black) and simulated by the model sampled at the surface, with constant (red) and time-varying wildfire emissions (orange). Trends over 1988-2014 are reported. (c) Interannual correlations of JJA mean MDA8 $\mathrm{O}_{3}$ observed at Yellowstone with JJA mean daily maximum temperature from observations (Harris et al., 2014).

the future $\mathrm{O}_{3}$ changes estimated by these prior studies do not represent baseline conditions, particularly the response to rising Asian emissions. In Fig. 14 we show changes in WUS free tropospheric $(700 \mathrm{hPa}) \mathrm{O}_{3}$ relative to 2010 in the CM3 future simulations under RCP8.5 versus RCP4.5. Historical hindcasts and observations are also shown for context. Under RCP4.5, springtime $\mathrm{O}_{3}$ over the WUS shows little overall change over 2010-2050. Under RCP8.5, in contrast, springtime WUS $\mathrm{O}_{3}$ increases by $\sim 10 \mathrm{ppb}$ from 2010 to 2030 and remains almost constant from 2030 to 2050, consistent with the projected trends in Asian emissions and global methane.

\subsection{Trends and variability of western $\mathrm{US} \mathrm{O}_{3}$ in summer}

Yellowstone National Park is the only site with statistically significant summer $\mathrm{O}_{3}$ increases observed across all percentiles (Fig. 8a-c). The 1988-2012 trends for the median observed and simulated $\mathrm{O}_{3}$ are summarized in Fig. 15a. Observations show an increase of $0.32 \pm 0.18 \mathrm{ppb} \mathrm{yr}^{-1}$ for JJA, with a greater rate of increase in June $\left(0.38 \pm 0.25 \mathrm{ppb} \mathrm{yr}^{-1}\right)$ than in July-August $\left(0.26 \pm 0.18 \mathrm{ppbyr}^{-1}\right)$. AM3 BASE sampled at $700 \mathrm{hPa}$ and filtered for baseline conditions (hatched pink bar in Fig. 15a) captures the observed increase. Without baseline filtering (solid pink bar), North American emission reductions offset almost $50 \%$ of the simulated 
$\mathrm{O}_{3}$ increase at Yellowstone, causing the model to underestimate the observed $\mathrm{O}_{3}$ trend. The model attributes much of the observed summer $\mathrm{O}_{3}$ increase at Yellowstone to rising Asian emissions, with IAVASIA simulating an $\mathrm{O}_{3}$ increase of $0.31 \pm 0.19 \mathrm{ppb} \mathrm{yr}^{-1}$ under baseline conditions, increasing to $0.42 \pm 0.23 \mathrm{ppb} \mathrm{yr}^{-1}$ under conditions of Asian influence (EACOt $\geq 67$ th percentile). The stronger increase measured in June than in July-August is consistent with the influence of the Asian summer monsoon producing a surface $\mathrm{O}_{3}$ minimum in July-August in East Asia (e.g., Lin et al., 2009), as well as the seasonality of intercontinental pollution transport. Changes in methane, wildfires, and meteorology over this period are of minor importance for the $\mathrm{JJA} \mathrm{O}_{3}$ trends at Yellowstone.

Enhanced wildfire activity in hot and dry weather is thought to be a key driver of interannual variability of surface $\mathrm{O}_{3}$ in the Intermountain West in summer (Jaffe et al., 2008; Jaffe, 2011). However, hot and dry conditions also facilitate the buildup of $\mathrm{O}_{3}$ produced from regional anthropogenic emissions, which can complicate the unambiguous attribution of observed $\mathrm{O}_{3}$ enhancements. Using August data at Yellowstone as an example, we isolate the relative contribution of these two processes to observed $\mathrm{O}_{3}$ with the IAVFIRE versus FIXEMIS experiments (Fig. 15b). Here we sample AM3 at the surface to account for any influence of varying boundary layer mixing depths. Even without interannual variations of wildfire emissions, FIXEMIS captures much of the observed year-to-year variability of August mean $\mathrm{O}_{3}$ at Yellowstone $(r=0.67)$. IAVFIRE with interannually varying fire emissions only moderately improves the correlations $(r=0.75)$. FIXEMIS also captures the observed $\mathrm{O}_{3}$ increase from the early 1990 s to around 2002 , likely reflecting warmer temperatures and deeper mixing depths allowing more baseline $\mathrm{O}_{3}$ to mix down to the surface. Over the entire 19882014 (or 1980-2014) period, IAVFIRE gives $\sim 0.1 \mathrm{ppb} \mathrm{yr}^{-1}$ greater $\mathrm{O}_{3}$ increases in August than FIXEMIS, consistent with an overall increase in boreal wildfire activity (Figs. S2 and S7b).

Figure 16 shows year-to-year variability in surface MDA8 $\mathrm{O}_{3}$ enhancements from wildfires during summer, as diagnosed by the differences between IAVFIRE and FIXEMIS. The results are shown for individual months since fires are highly episodic. During the summers of 1998, 2002, and 2003, biomass fires burned a large area of Siberia and parts of the North American boreal forests, raising carbon monoxide across the Northern Hemisphere as detected from space (Yurganov et al., 2005; van der Werf et al., 2010). Longrange transport of Siberian fire plumes resulted in 2-6 ppb enhancements in surface MDA8 $\mathrm{O}_{3}$ at the US western coast and in parts of the Intermountain West in AM3. The model calculates enhancements in monthly mean MDA8 $\mathrm{O}_{3}$ of up to $8 \mathrm{ppb}$ from the intense wildfire events in northern California during July 2008 (Huang et al., 2013; Pfister et al., 2013), over Texas-Mexico during June 2011 (Wang et al., 2015), and in Wyoming-Utah during August 2012 (Jaffe et al., 2013). The AM3 estimates are roughly consistent with a previous analysis of boundary layer aircraft data with and without fire influences (as diagnosed by $\mathrm{CH}_{3} \mathrm{CN}$ ) during June 2008 over California (Pfister et al., 2013).

While fires during hot and dry summers clearly result in enhanced $\mathrm{O}_{3}$ at individual sites for some summers, the ability of AM3 with constant fire emissions to simulate variability of $\mathrm{O}_{3}$ for a high (e.g., 1988, 2002, 2006) versus low (e.g., 1997, 2009) fire year (Fig. 15b) indicates that biomass burning is not the primary driver of observed $\mathrm{O}_{3}$ interannual variability. Year-to-year variability of JJA mean MDA8 $\mathrm{O}_{3}$ observed at Yellowstone is strongly correlated $(r>0.6)$ with observed large-scale variations in JJA mean daily maximum temperature across the Intermountain West (Fig. 15c). Correlations for other ground stations show a similar large-scale feature. Similar to the conclusion from Zhang et al. (2014), our analysis indicates that the correlation between $\mathrm{O}_{3}$ and biomass burning reported by Jaffe et al. (2008) and Jaffe (2011) at rural sites reflects common underlying correlations with temperature rather than a causal relationship of fire with $\mathrm{O}_{3}$. At remote mountain sites (e.g., Yellowstone), warmer surface temperatures lead to deeper mixed layers that facilitate mixing of free tropospheric $\mathrm{O}_{3}$-rich air down to the surface. At sites near sources of air pollution, hot conditions enhance regional $\mathrm{O}_{3}$ production and orographic lifting of urban pollution to mountaintop sites during daytime, as occurs at Rocky Mountain National Park located downwind of the Denver metropolitan area during summer (Sect. 5.4). Reactive volatile organic compound (VOC) emissions from fires may enhance $\mathrm{O}_{3}$ production in $\mathrm{NO}_{x}$-rich urban areas (Baker et al., 2016), although evaluating these impacts needs highresolution models and better treatment of sub-grid-scale fire plumes.

\subsection{Ozone trends in the Denver metropolitan area}

Efforts to improve air quality have led to a marked decrease in high- $\mathrm{O}_{3}$ events in the Los Angeles Basin as illustrated by the annual 4th highest MDA8 $\mathrm{O}_{3}$ at Crestline - a regionally representative monitor operated continuously from 1980 to the present (Fig. 17a). In striking contrast, the 4th highest MDA8 $\mathrm{O}_{3}$ in the Denver metropolitan area shows little change over the past decades, despite significant reductions in $\mathrm{NO}_{x}$ (Fig. 1) and CO emissions ( $-80 \%$ from 1990 to 2010; Cooper et al., 2012). Recent field measurements indicate that increased VOC emissions from oil and natural gas operations are an important source of $\mathrm{O}_{3}$ precursors in the Denver-Julesberg Basin (Gilman et al., 2013; Halliday et al., 2016; McDuffie et al., 2016). However, total VOC emissions in Denver may not be increasing over time due to the marked reductions in VOC emissions from vehicles (Bishop and Stedman, 2008, 2015). We seek insights into the causes of the lack of significant $\mathrm{O}_{3}$ responses to emission controls in Denver by separately analyzing trends in spring and summer (Fig. 17b-c). 


\section{IAVFIRE - FIXEMIS: surface MDA8 O3 anomaly}

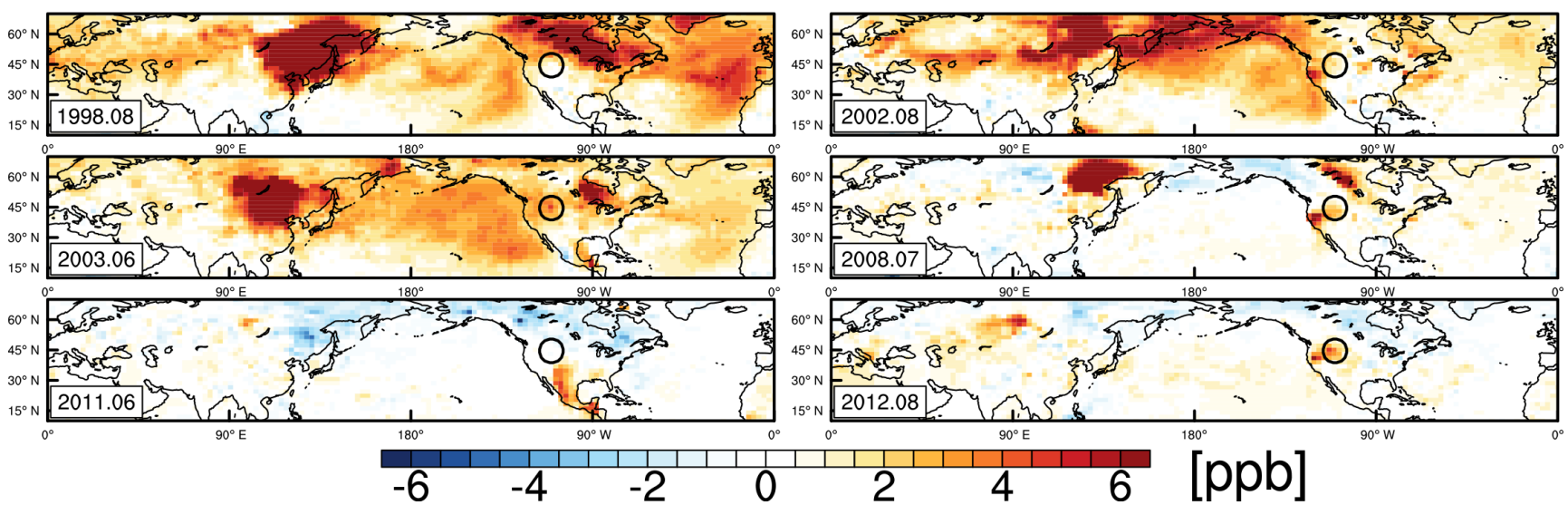

Figure 16. Surface $\mathrm{MDA} 8 \mathrm{O}_{3}$ enhancements from wildfire emissions for individual months in the years with large biomass burning in boreal regions $(1998,2002,2003)$ and over the WUS $(2008,2011,2012)$, as diagnosed by the differences between IAVFIRE and FIXEMIS. The black circle denotes the location of Yellowstone National Park.

The $\sim 200 \times 200 \mathrm{~km}^{2}$ AM3 model is not expected to resolve the urban-to-rural differences between Rocky Mountain National Park and the Denver metropolitan area. However, if observed $\mathrm{O}_{3}$ variability in Denver correlates with that at remote sites in the Intermountain West, then model attribution for the remote sites can be used to infer sources of observed $\mathrm{O}_{3}$ in Denver. This is demonstrated in Fig. 17b for spring using data at three representative sites in Denver, Rocky Flats North, National Renewable Energy Lab (NREL), and Welby, with continuous measurements since the early 1990s. Year-to-year variability of median MDA8 $\mathrm{O}_{3}$ at these sites during spring correlates strongly with that in Great Basin National Park $(r=0.7)$, a fairly remote site in Nevada not influenced by urban emissions from Denver. Median spring $\mathrm{O}_{3}$ observations in Denver increased significantly by $\sim 0.3 \mathrm{ppb} \mathrm{yr}^{-1}$, similar to the rate of increase in Great Basin National Park, which the model attributes to rising background (Fig. 13a), implying that the tripling of Asian emissions since 1990 also raised mean springtime $\mathrm{O}_{3}$ in the Denver metropolitan area. Trends in the 95th percentile are statistically insignificant.

During summer, changes in regional emissions and temperature have the greatest impacts on the highest observed $\mathrm{O}_{3}$ concentrations in polluted environments. Figure $17 \mathrm{c}$ shows times series of July-August 95th percentile MDA8 $\mathrm{O}_{3}$ in Denver, together with the distribution of daily maximum temperature. In every year since 1993, the highest summer MDA8 $\mathrm{O}_{3}$ observed at these sites exceeds the $70 \mathrm{ppb}$ NAAQS level. There is a small negative trend that is swamped by large interannual variability. The summers with the highest observed $\mathrm{O}_{3}$ coincide with those with the highest observed temperatures, such as 1998, 2003, 2007, 2011 and 2012. During these summers, enhancements of MDA8 $\mathrm{O}_{3}$ were also recorded in Rocky Mountain National Park, reflect- ing enhanced lifting of pollution from Denver under warmer conditions (Brodin et al., 2010). Applying quantile regression (e.g., Porter et al., 2015) to daily observations at Rocky Flats North over $1993-2015$, we find a $2 \mathrm{ppb}^{\circ} \mathrm{C}^{-1}$ sensitivity of 95th percentile July-August $\mathrm{O}_{3}$ to changes in maximum daily temperature. We suggest that the substantial increases in extreme heat occurrence over central North America over the last 2 decades, as found by Horton et al. (2015), contribute to raising summer $\mathrm{O}_{3}$ in Denver, which offsets $\mathrm{O}_{3}$ reductions that otherwise would have occurred due to emission controls in Denver. Potential shifts in the $\mathrm{O}_{3}$ photochemistry regime can also contribute to trends of summer $\mathrm{O}_{3}$ in Denver, although advancing this knowledge would require a high-resolution air quality model.

\section{Impacts of heat waves and droughts on eastern US summer $\mathrm{O}_{3}$}

We discuss in this section interannual variability and longterm changes in summer $\mathrm{O}_{3}$ over the EUS, where air stagnation and high temperatures typically yield the highest $\mathrm{O}_{3}$ observed in surface air (e.g., Jacob and Winner, 2009). Evaluating the ability of models to simulate the high- $\mathrm{O}_{3}$ anomalies during historical heat waves and droughts is crucial to establishing confidence in the model projection of pollution extremes under a warming climate. Figure 18a shows comparisons of July mean MDA8 $\mathrm{O}_{3}$ at one regionally representative site, the Pennsylvania State University (PSU) CASTNet site, from observations and model simulations. With time-varying emissions, the BASE model simulates an $\mathrm{O}_{3}$ decrease $\left(-0.45 \pm 0.32 \mathrm{ppb} \mathrm{yr}^{-1}\right)$ consistent with observations $\left(-0.67 \pm 0.33 \mathrm{ppb} \mathrm{yr}^{-1}\right)$ and captures the observed July mean $\mathrm{O}_{3}$ interannual variability $(r=0.82)$ that is correlated with large-scale variations in daily maximum temperature 

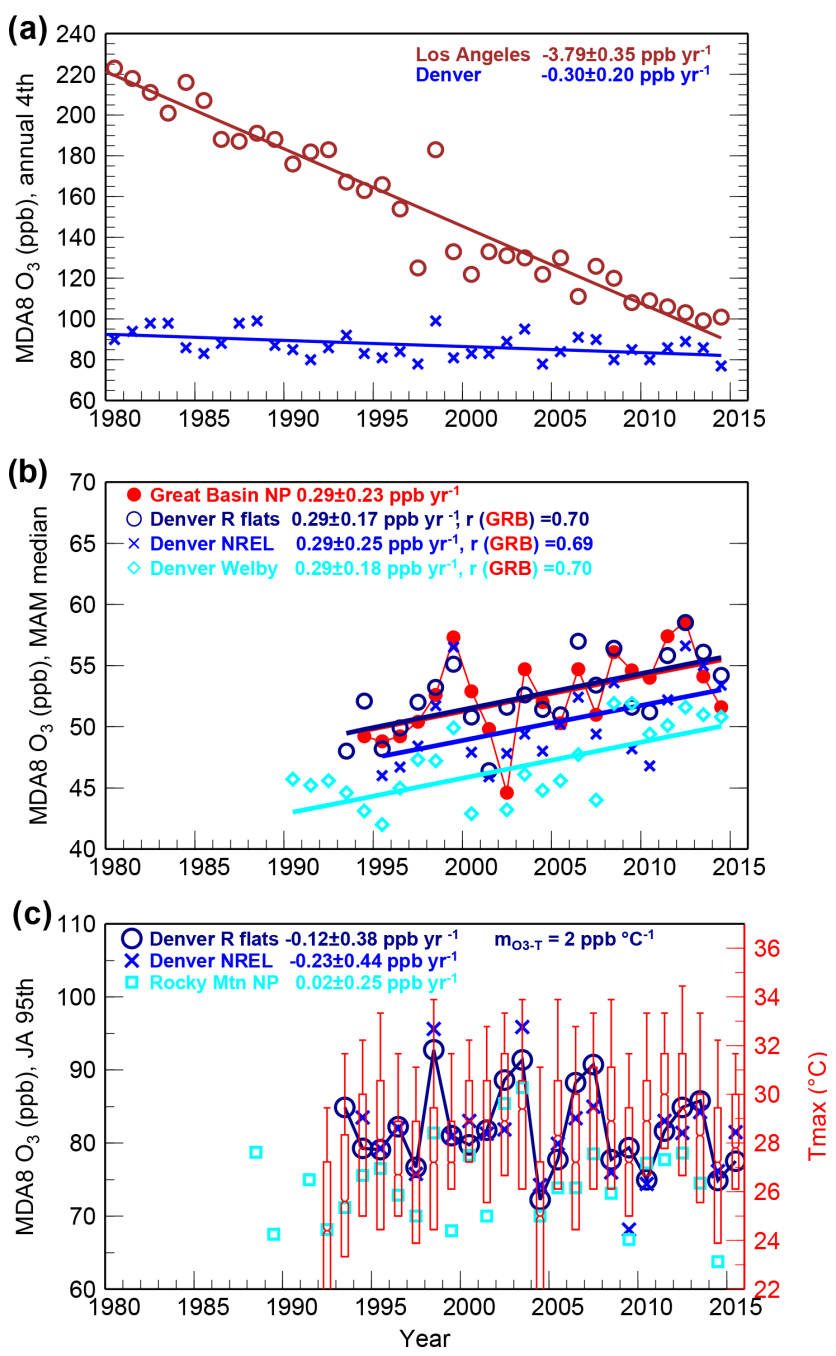

Figure 17. Surface $\mathrm{O}_{3}$ trends in Denver. (a) Comparison of observed trends in annual fourth highest MDA8 $\mathrm{O}_{3}$ at Crestline Los Angeles (brown) and in Denver (blue, computed from all monitors available in Denver non-attainment counties). (b) Time series of observed median MAM MDA8 $\mathrm{O}_{3}$ at Great Basin National Park (red), in comparison with three monitors in Denver. (c) Time series of observed 95th percentile July-August MDA8 $\mathrm{O}_{3}$ in Denver, together with statistics (25th, 50th, 75th, 95th) of observed JulyAugust daily maximum temperature at Rocky Flats (red, right axis).

$(r=0.57)$. In particular, $\mathrm{O}_{3}$ pollution extremes are successfully simulated during the EUS summer heat waves of 1988, 1995, 1999, 2002, 2011 and 2012 (Leibensperger et al., 2008; Fiore et al., 2015; Jia et al., 2016). Year-to-year variations in meteorology can explain $30 \%$ of the total observed $\mathrm{O}_{3}$ variability $(r=0.55)$, as inferred by FIXEMIS with constant anthropogenic emissions. If US anthropogenic emissions remained at 1990s levels (as in FIXEMIS), then anomalies in July mean $\mathrm{MDA} 8 \mathrm{O}_{3}$ would have been $10 \mathrm{ppb}$ greater during the 2011 and 2012 heat waves. Loughner et al. (2014) found that half of the days in July 2011 would have been classified
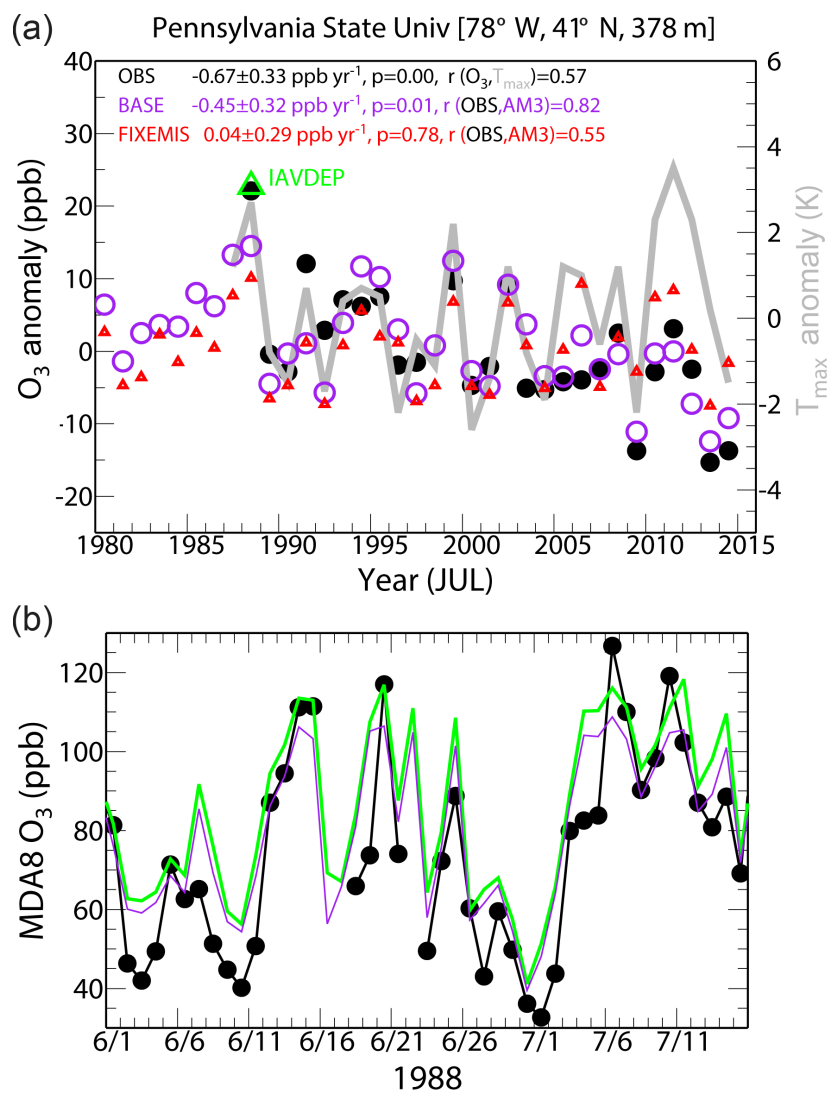

Figure 18. (a) Time series of July mean $\mathrm{MDA}_{8} \mathrm{O}_{3}$ anomalies (relative to 1988-2014) at the Pennsylvania State University (PSU) CASTNET site as observed (black) and simulated by the GFDLAM3 model with time-varying (purple) and constant anthropogenic emissions (red), along with observed anomalies in July mean daily max temperature (gray lines; right axis). The green triangle denotes the $1988 \mathrm{O}_{3}$ anomaly from a sensitivity simulation using BASE emissions but with $35 \%$ decreases in $V_{\mathrm{d}, \mathrm{O}_{3}}$ (IAVDEP). (b) Time series of daily MDA8 $\mathrm{O}_{3}$ at PSU from 1 June to 16 July in 1988 from observations (black), BASE (purple), and IAVDEP simulations (green).

as $\mathrm{O}_{3}$ exceedance days for much of the mid-Atlantic region if emissions had not declined.

Figure 19a compares the probability density functions of MDA8 $\mathrm{O}_{3}$ at 40 EUS surface sites for JJA in the pre-NO $\mathrm{NO}_{x}$ SIP Call (1988-2002) versus post-NO ${ }_{x}$ SIP Call (2003-2014) periods and during the extreme heat waves of 1988 versus 2012. Following the $\mathrm{NO}_{x}$ SIP Call, the probability distribution of observed JJA MDA8 $\mathrm{O}_{3}$ over the EUS shifted downward (solid black versus dotted gray lines in Fig. 19a). The median value declined by $9 \mathrm{ppb}$ and the largest decreases occurred in the upper tails, leading to weaker day-to-day $\mathrm{O}_{3}$ variability and a narrower $\mathrm{O}_{3}$ range (standard deviation $\sigma$ decreased from 16.4 to $12.9 \mathrm{ppb}$ ). These observed $\mathrm{O}_{3}$ changes driven by regional $\mathrm{NO}_{x}$ reductions are even more prominent when comparing the heat waves of 1988 versus 2012 (solid 

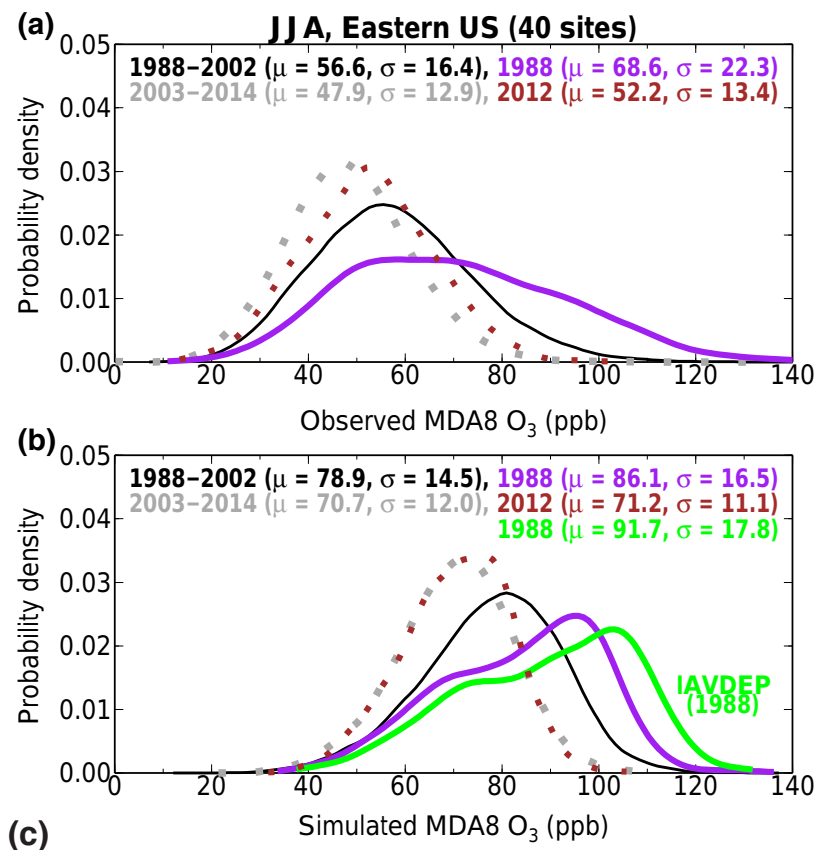

(c)

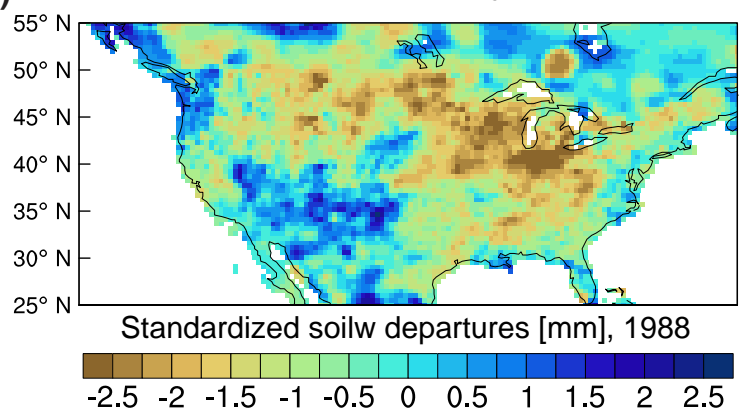

Figure 19. (a) Comparisons of probability distributions of summertime MDA8 $\mathrm{O}_{3}$ from 40 EUS CASTNet sites for the pre-NO $\mathrm{NO}_{x}$ SIP Call (1988-2002; solid black) versus post-NOx SIP Call (20032014; dashed gray) periods and during the extreme heat waves of 1988 (solid purple) versus 2012 (dashed brown). The median $(\mu)$ and standard deviation $(\sigma)$ are shown (ppb). (b) Same as (a), but from AM3 BASE. Also shown is the $\mathrm{O}_{3}$ distribution in 1988 from a sensitivity simulation with $35 \%$ decreases in $V_{\mathrm{d}, \mathrm{O}_{3}}$ in drought areas (green). (c) Standardized soil moisture departures for JJA 1988 (calculated by dividing anomalies by the 1979-2010 climatological standard deviation, using data from the NOAA Climate Prediction Center)

purple versus dotted brown lines in Fig. 19a): $\sigma=22.3$ versus $13.4 \mathrm{ppb}$ and median value $\mu=68.6$ versus $52.2 \mathrm{ppb}$.

Figure $19 \mathrm{~b}$ shows the corresponding comparisons using the results from AM3 BASE. Despite the high mean model bias $(\sim 20 \mathrm{ppb})$, AM3 captures the overall structure of the changes in the surface $\mathrm{O}_{3}$ distributions and thus the response of surface $\mathrm{O}_{3}$ to the $\mathrm{NO}_{x}$ SIP Call, including the reductions of high- $\mathrm{O}_{3}$ events during the heat wave of 2012 compared to 1988. Nevertheless, there is a noticeable difference between the observations and simulations in the shape of MDA8 $\mathrm{O}_{3}$ probability distributions for summer 1988 , particularly in the upper tail of the distribution above $110 \mathrm{ppb}$ (purple lines in Fig. 19a versus b). The BASE model also underestimates the observed July mean $\mathrm{O}_{3}$ anomaly at PSU in 1988 by $\sim 10 \mathrm{ppb}$ (purple versus black dots in Fig. 18a). One possible explanation for these biases is that drought stress can effectively reduce the $\mathrm{O}_{3}$ deposition sink to vegetation, leading to an increase in surface $\mathrm{O}_{3}$ concentrations as found during the 2003 European heat wave (Solberg et al., 2008), whereas AM3 does not include interannually varying dry deposition velocities.

The North American drought of 1988 ranks among the worst episodes of drought in the US (e.g., Seager and Hoerling, 2014), with JJA soil moisture deficits occurring over the northern Great Plains-Midwest region with magnitudes of 1 $2.5 \mathrm{~mm}$ standardized departures from the 1979-2010 climatology (Fig. 19c). Huang et al. (2016) found that monthly mean $\mathrm{O}_{3}$ dry deposition velocities $\left(V_{\mathrm{d}, \mathrm{O}_{3}}\right)$ for forests decreased by $33 \%$ over Texas during the dry summer of 2011. Based on this estimate, we conduct a sensitivity simulation for 1988 using BASE emissions but decreasing monthly mean $\mathrm{V}_{\mathrm{d}, \mathrm{O}_{3}}$ from May to August by $35 \%$ in the areas over North America $\left(20-60^{\circ} \mathrm{N}\right)$ where soil moisture deficits in 1988 exceed $-1.0 \sigma \mathrm{mm}$ (Fig. 19c). This experiment (hereafter referred to as IAVDEP) simulates $\sim 10$ ppb higher July mean MDA8 $\mathrm{O}_{3}$ at the PSU CASTNet site than the BASE model and matches the observed $\mathrm{O}_{3}$ anomaly in 1988 relative to the record mean (green symbol in Fig. 18a). The impact is largest (up to $15 \mathrm{ppb}$ ) on days when observed MDA8 $\mathrm{O}_{3}$ exceeds $100 \mathrm{ppb}$ (Fig. $18 \mathrm{~b} ; T_{\max } \geq 30^{\circ} \mathrm{C}$ ). Simulated JJA MDA8 $\mathrm{O}_{3}$ at EUS sites in IAVDEP shows an upward shift in the probability distribution, particularly in the upper tail above $110 \mathrm{ppb}$ (green versus purple lines in Fig. 19b), bringing it closer to observations in 1988 (Fig. 19a). The $\mathrm{O}_{3}$ standard deviation in IAVDEP $(\sigma=18 \mathrm{ppb})$ shifts towards that in observations $(\sigma=22 \mathrm{ppb})$ relative to the BASE model $(\sigma=16 \mathrm{ppb})$.

Quantile mapping can be applied to correct systematic distributional biases in surface $\mathrm{O}_{3}$ compared to observations (Rieder et al., 2015), but this approach has limitations if there are structural biases in the $\mathrm{O}_{3}$ distribution due to missing physical processes in the model (e.g., variations of $\mathrm{V}_{\mathrm{d}, \mathrm{O}_{3}}$ with droughts). Travis et al. (2016) suggest that the National Emission Inventory (NEI) for $\mathrm{NO}_{x}$ from the US EPA is too high nationally by $50 \%$. Decreasing US $\mathrm{NO}_{x}$ emissions by this amount corrects their model bias for boundary layer $\mathrm{O}_{3}$ by $12 \mathrm{ppb}$ in the southeast for summer 2013, while surface MDA8 $\mathrm{O}_{3}$ in their model is still biased high by $6 \pm 14 \mathrm{ppb}$, which the authors attribute to excessive boundary layer mixing. US $\mathrm{NO}_{x}$ emissions in the emission inventory used in AM3 (Sect. 2.2) are approximately $15 \%$ lower than those from the NEI. The $35 \%$ decrease in $\mathrm{NO}_{x}$ emissions from the pre- $\mathrm{NO}_{x}$ SIP Call to the post-NO $\mathrm{N}_{x}$ SIP Call in the model reduces mean $\mathrm{O}_{3}$ by 8 ppb in the EUS, implying that the $\mathrm{NO}_{x}$ emission bias could correct $40 \%$ of our model mean bias of $\sim 20 \mathrm{ppb}$. These estimates support the idea that the common 


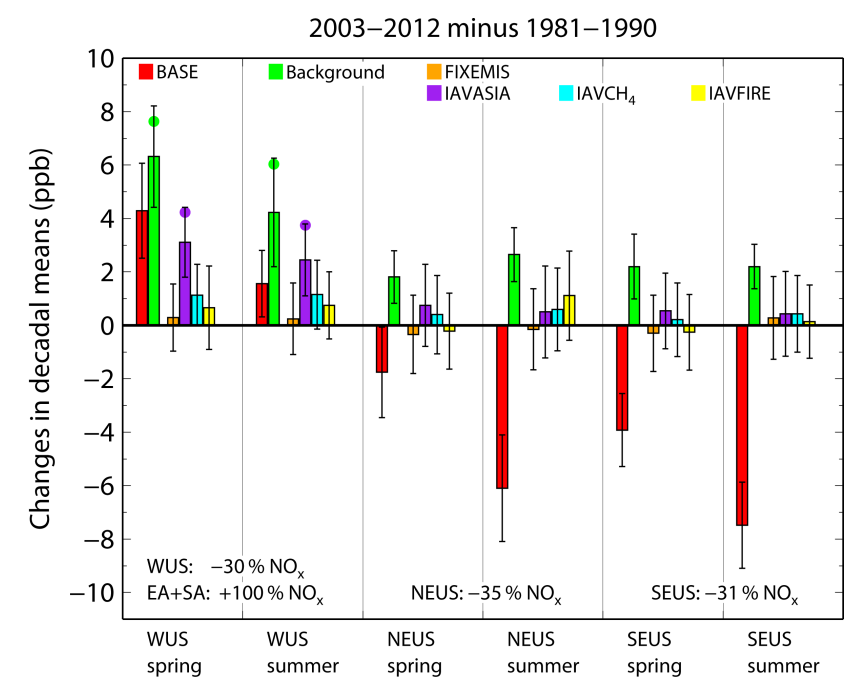

Figure 20. Summary of US surface $\mathrm{O}_{3}$ trends and drivers. Changes in decadal mean MDA8 $\mathrm{O}_{3}$ from 1981-1990 to 2003-2012 simulated in a suite of GFDL-AM3 experiments for spring and summer for the western $\left(32-46^{\circ} \mathrm{N}\right.$ and $\left.123-102^{\circ} \mathrm{W}\right)$, northeastern $(37-$ $45^{\circ} \mathrm{N}$ and $\left.90-65^{\circ} \mathrm{W}\right)$ and southeastern $\left(30-36^{\circ} \mathrm{N}\right.$ and $\left.95-77^{\circ} \mathrm{W}\right)$ US domains. Observations are not shown because limited data are available during 1981-1990. Experiments are color-coded, with the error bars indicating the range of the mean change at the $95 \%$ confidence level. Filled circles represent the changes under Background (green) and IAVASIA (purple) when filtered for Asian influence (EACOt $\geq 67$ th), while other results are from the unfiltered models. The text near the bottom of the plot provides the change in $\mathrm{NO}_{x}$ emissions over the same period for each region.

model biases in simulating surface $\mathrm{O}_{3}$ over the southeastern US (e.g., Fiore et al., 2009) may partly reflect excessive $\mathrm{NO}_{x}$ emissions. Some of the positive $\mathrm{O}_{3}$ biases could be also due to the averaging over a deep vertical box in the model surface layer ( $\sim 60 \mathrm{~m}$ in AM3) that can not resolve near-surface gradients (Travis et al., 2016).

\section{Conclusions and recommendations}

Through an observational and modeling analysis of interannual variability and long-term trends in sources of $\mathrm{O}_{3}$ over the past 35 years, we have identified the key drivers of $\mathrm{O}_{3}$ pollution over the US. We initially evaluated the trends of $\mathrm{O}_{3}$ in Asia resulting from rising Asian precursor emissions (Figs. 4-6). Our synthesis of available observations and simulations indicates that surface $\mathrm{O}_{3}$ over East Asia has increased by $1-2 \mathrm{ppb} \mathrm{yr}^{-1}$ since 1990 (i.e., $25-50 \mathrm{ppb}$ over 25 years), with significant implications for regional air quality and global tropospheric $\mathrm{O}_{3}$ burden. Shifting next to the US, we find $0.2-0.5 \mathrm{ppbyr}^{-1}$ increases in median springtime MDA8 $\mathrm{O}_{3}$ measured at $50 \%$ of 16 WUS rural sites, with $25 \%$ of the sites showing increases across the entire $\mathrm{O}_{3}$ concentration distribution, despite stringent US domestic emission controls (Fig. 7). While many prior studies show that global models have difficulty simulating $\mathrm{O}_{3}$ increases observed at rural baseline sites (e.g., Parrish et al., 2014; Strode et al., 2015), we reconcile observed and simulated $\mathrm{O}_{3}$ trends in GFDL-AM3 with a novel baseline sampling approach (Figs. 3 and 13). We suggest that the common modelobservation disagreement in baseline $\mathrm{O}_{3}$ trends reflects limitations of coarse-resolution global models in resolving observed baseline conditions. This representativeness problem can be addressed by filtering model $\mathrm{O}_{3}$ for hemisphericscale baseline conditions using the easy-to-implement, lowcost regional CO-like tracers. This approach allows trends of $\mathrm{O}_{3}$ measured at baseline sites to be compared directly with multi-decadal global model hindcasts, such as those being conducted for the Chemistry-Climate Model Initiative (CCMI; Morgenstern et al., 2017).

The ability of the GFDL-AM3 model to reproduce observed US surface $\mathrm{O}_{3}$ trends lends confidence in its application to attribute these observed trends to specific processes (Figs. 7 to 11). We summarize the overall statistics in Fig. 20, drawing upon the decadal mean $\mathrm{O}_{3}$ changes from 19811990 to 2003-2012 in the BASE and sensitivity simulations. The changes in BASE are over the WUS $4.3 \pm 1.8 \mathrm{ppb}$ for spring and $1.6 \pm 1.2 \mathrm{ppb}$ for summer; over the northeast, $-1.8 \pm 1.7 \mathrm{ppb}$ for spring and $-6.0 \pm 2.0 \mathrm{ppb}$ for summer; and over the southeast, $-3.9 \pm 1.4 \mathrm{ppb}$ for spring and $-7.5 \pm 1.6 \mathrm{ppb}$ for summer. Increasing $\mathrm{O}_{3}$ in the WUS under BASE coincides with an increase in background $\mathrm{O}_{3}$ by $6.3 \pm 1.9 \mathrm{ppb}$ for spring and $4.2 \pm 2.0 \mathrm{ppb}$ for summer. Under conditions of strong transport from Asia (East Asian $\mathrm{COt} \geq 67 \mathrm{th}$ ), the background trend rose to $7.6 \pm 2.2 \mathrm{ppb}$ for spring and $6.0 \pm 2.1 \mathrm{ppb}$ for summer (green dots in Fig. 20). The WUS background $\mathrm{O}_{3}$ increase reflects contributions from increases in Asian anthropogenic emissions (accounting for $50 \%$ of background increase in spring; $52 \%$ in summer), rising global methane (13\% in spring; $23 \%$ in summer), and variability in biomass burning (6\% in spring; $12 \%$ in summer; excluding the meteorological influence).

We conclude that the increase in Asian anthropogenic emissions is the major driver of rising background $\mathrm{O}_{3}$ over the WUS for both spring and summer in the past decades, with a lesser contribution from methane increases over this period. The tripling of Asian $\mathrm{NO}_{x}$ emissions since 1990 contributes up to $65 \%$ of modeled springtime background $\mathrm{O}_{3}$ increases $\left(0.3-0.5 \mathrm{ppb} \mathrm{yr}^{-1}\right)$ over the WUS, outpacing $\mathrm{O}_{3}$ decreases resulting from $50 \%$ US $\mathrm{NO}_{x}$ emission controls ( $\leq 0.1 \mathrm{ppb} \mathrm{yr}^{-1}$; Table 2 and Fig. 10). Springtime $\mathrm{O}_{3}$ observed in the Denver metropolitan area has increased at a rate similar to remote rural sites (Fig. 17b). Mean springtime $\mathrm{O}_{3}$ above the WUS is projected to increase by $\sim 10 \mathrm{ppb}$ from 2010 to 2030 under the RCP8.5 global change scenario but to remain constant throughout 2010 to 2050 under the RCP4.5 scenario (Fig. 14). As $\mathrm{NO}_{x}$ emissions in China continue to decline in response to efforts to improve air quality (Krotkov et al., 2016; Liu et al., 2016), rising global methane 
and $\mathrm{NO}_{x}$ emissions in the tropical countries (e.g., India) in Asia, where $\mathrm{O}_{3}$ production is more efficient, may become more important in the coming decades. A global perspective is necessary when designing a strategy to meet $\mathrm{US} \mathrm{O}_{3}$ air quality objectives.

During summer, a tripling of Asian anthropogenic emissions from 1988 to 2014 approximately offsets the benefits of $50 \%$ reductions in US domestic emissions, leading to weak or insignificant $\mathrm{O}_{3}$ trends observed at most WUS rural sites (Figs. 8 and 11). Rising Asian emissions contribute to observed summertime $\mathrm{O}_{3}$ increases $\left(0.3 \mathrm{ppb} \mathrm{yr}^{-1}\right)$ at Yellowstone National Park. Our findings confirm the earliest projection of Jacob et al. (1999) with a tripling of Asian emissions. While wildfire emissions can result in 2-8 ppb enhancements to monthly mean $\mathrm{O}_{3}$ at individual sites in some summers, they are not the primary driver of observed $\mathrm{O}_{3}$ interannual variability over the Intermountain West (Figs. 15 and 16). Instead, boundary layer depth, high temperatures and the associated buildup of $\mathrm{O}_{3}$ produced from regional anthropogenic emissions contribute most to the observed interannual variability of $\mathrm{O}_{3}$ in summer. Summertime $\mathrm{O}_{3}$ measured in Denver during pollution episodes frequently exceeds the $70 \mathrm{ppb}$ NAAQS level, with little overall trend despite stringent precursor emission controls (Fig. 17c), likely due to the effects of more frequent occurrences of hot extremes in the last decade.

In the eastern US, if emissions had not declined, the 95th percentile summertime $\mathrm{O}_{3}$ would have increased by $0.2-$ $0.4 \mathrm{ppb} \mathrm{yr}^{-1}$ over 1988-2014 (Fig. 11c), due to more frequent hot summer extremes and increases in biogenic isoprene emissions (1-2\% $\mathrm{yr}^{-1}$ ) over this period (Fig. 12). Regional $\mathrm{NO}_{x}$ reductions alleviated the $\mathrm{O}_{3}$ buildup during the recent heat waves of 2011 and 2012 relative to earlier heat waves (e.g., 1988, 1995, 1999). GFDL-AM3 captures yearto-year variability in monthly mean $\mathrm{O}_{3}$ enhancements associated with large-scale variations in temperatures (Figs. 18 and 19). However, there is a need to improve the model representation of $\mathrm{O}_{3}$ deposition sink to vegetation, in particular its reduced efficiency under drought stress, as we demonstrated for the severe North American drought of 1988. Such landbiosphere couplings are poorly represented in current models and further work is needed to examine their impacts on $\mathrm{O}_{3}$ pollution extremes in a warming climate.

Following the $\mathrm{NO}_{x}$ SIP Call, surface $\mathrm{O}_{3}$ in the eastern US declined throughout its probability distribution, with the largest decreases occurring in the highest percentiles during summer $\left(-0.8\right.$ to $-1.8 \mathrm{ppb} \mathrm{yr}^{-1}$; Fig. 8$)$. Spatially, historical $\mathrm{O}_{3}$ decreases during non-summer seasons were more pronounced in the southeast, where the seasonal onset of biogenic isoprene emissions and $\mathrm{NO}_{x}$-sensitive $\mathrm{O}_{3}$ production occurs earlier than in the northeast (Figs. 7, 9 and S4). The 95th percentile $\mathrm{O}_{3}$ concentration in the southeast has even decreased during winter. Despite high mean-state biases, GFDL-AM3 captures the salient features of observed $\mathrm{O}_{3}$ trends over the eastern US, including wintertime increases in the 5th and 50th percentiles in the northeast, greater springtime decreases in the southeast than the northeast, and summertime decreases throughout the $\mathrm{O}_{3}$ concentration distribution. These results suggest that $\mathrm{NO}_{x}$ emission controls will continue to provide long-term $\mathrm{O}_{3}$ air quality benefits in the southeastern US during all seasons.

\section{Data availability}

All data derived from observations and model simulations used in this study are archived at NOAA GFDL and are available to the public upon request to Meiyun Lin.

\section{The Supplement related to this article is available online at doi:10.5194/acp-17-2943-2017-supplement.}

Competing interests. The authors declare that they have no conflict of interest.

Acknowledgements. This work was supported by funding from NASA grants NNH13ZDA001N-AURAST and NNX14AR47G to Meiyun Lin. We thank O. Cooper, S. Fan and J. Schnell for helpful comments on the manuscript. We acknowledge the free use of ozonesonde data at Hong Kong available on www.woudc.org and GOME-SCIAMACHY tropospheric $\mathrm{NO}_{2}$ column data available on www.temis.nl. Arlene M. Fiore acknowledges support under EPA Assistance Agreement no. 83587801. The views expressed in this document are solely those of the authors and do not necessarily reflect those of the agency. Meiyun Lin devotes this article to her father Tianci Lin, who is the motivation of her life and research career.

Edited by: B. N. Duncan

Reviewed by: two anonymous referees

\section{References}

Abatzoglou, J. T. and Williams, A. P.: Impact of anthropogenic climate change on wildfire across western US forests, P. Natl. Acad. Sci. USA, 113, 11770-11775, doi:10.1073/pnas.1607171113, 2016.

Baker, K. R., Woody, M. C., Tonnesen, G. S., Hutzell, W., Pye, H. O. T., Beaver, M. R., Pouliot, G., and Pierce, T.: Contribution of regional-scale fire events to ozone and $\mathrm{PM}_{2.5}$ air quality estimated by photochemical modeling approaches, Atmos. Environ., 140, 539-554, doi:10.1016/j.atmosenv.2016.06.032, 2016.

Barnes, E. A., Fiore, A. M., and Horowitz, L. W.: Detection of trends in surface ozone in the presence of climate variability, J. Geophys. Res., 121, 6112-6129, doi:10.1002/2015jd024397, 2016.

Bishop, G. A. and Stedman, D. H.: A decade of on-road emissions measurements, Environ. Sci. Technol., 42, 1651-1656, doi:10.1021/es702413b, 2008. 
Bishop, G. A. and Stedman, D. H.: Reactive Nitrogen Species Emission Trends in Three Light-/Medium-Duty United States Fleets, Environ. Sci. Technol., 49, 11234-11240, doi:10.1021/acs.est.5b02392, 2015.

Boersma, K. F., Eskes, H. J., and Brinksma, E. J.: Error analysis for tropospheric NO2 retrieval from space, J. Geophys. Res., 109, D04311, doi:10.1029/2003jd003962, 2004.

Brodin, M., Helmig, D., and Oltmans, S.: Seasonal ozone behavior along an elevation gradient in the Colorado Front Range Mountains, Atmos. Environ., 44, 5305-5315, doi:10.1016/j.atmosenv.2010.06.033, 2010.

Brown-Steiner, B. and Hess, P.: Asian influence on surface ozone in the United States: A comparison of chemistry, seasonality, and transport mechanisms, J. Geophys. Res., 116, D17309, doi:10.1029/2011jd015846, 2011.

Brown-Steiner, B., Hess, P. G., and Lin, M. Y.: On the capabilities and limitations of GCCM simulations of summertime regional air quality: A diagnostic analysis of ozone and temperature simulations in the US using CESM CAM-Chem, Atmos. Environ., 101, 134-148, doi:10.1016/j.atmosenv.2014.11.001, 2015.

Carmichael, G. R., Tang, Y., Kurata, G., Uno, I., Streets, D., Woo, J. H., Huang, H., Yienger, J., Lefer, B., Shetter, R., Blake, D., Atlas, E., Fried, A., Apel, E., Eisele, F., Cantrell, C., Avery, M., Barrick, J., Sachse, G., Brune, W., Sandholm, S., Kondo, Y., Singh, H., Talbot, R., Bandy, A., Thorton, D., Clarke, A., and Heikes, B.: Regional-scale chemical transport modeling in support of the analysis of observations obtained during the TRACE-P experiment, J. Geophys. Res., 108, 8823, doi:10.1029/2002jd003117, 2003.

Clifton, O. E., Fiore, A. M., Correa, G., Horowitz, L. W., and Naik, V.: Twenty-first century reversal of the surface ozone seasonal cycle over the northeastern United States, Geophys. Res. Lett., 41, 7343-7350, doi:10.1002/2014g1061378, 2014.

Cooper, O. R., Parrish, D. D., Stohl, A., Trainer, M., Nedelec, P., Thouret, V., Cammas, J. P., Oltmans, S. J., Johnson, B. J., Tarasick, D., Leblanc, T., McDermid, I. S., Jaffe, D., Gao, R., Stith, J., Ryerson, T., Aikin, K., Campos, T., Weinheimer, A., and Avery, M. A.: Increasing springtime ozone mixing ratios in the free troposphere over western North America, Nature, 463, 344-348, doi:10.1038/nature08708, 2010.

Cooper, O. R., Gao, R.-S., Tarasick, D., Leblanc, T., and Sweeney, C.: Long-term ozone trends at rural ozone monitoring sites across the United States, 1990-2010, J. Geophys. Res., 117, D22307, doi:10.1029/2012JD018261, 2012.

Dennison, P. E., Brewer, S. C., Arnold, J. D., and Moritz, M. A.: Large wildfire trends in the western United States, 1984-2011, Geophys. Res. Lett., 41, 2928-2933, doi:10.1002/2014g1059576, 2014.

Dentener, F., Kinne, S., Bond, T., Boucher, O., Cofala, J., Generoso, S., Ginoux, P., Gong, S., Hoelzemann, J. J., Ito, A., Marelli, L., Penner, J. E., Putaud, J.-P., Textor, C., Schulz, M., van der Werf, G. R., and Wilson, J.: Emissions of primary aerosol and precursor gases in the years 2000 and 1750 prescribed data-sets for AeroCom, Atmos. Chem. Phys., 6, 4321-4344, doi:10.5194/acp-64321-2006, 2006.

Ding, A. J., Wang, T., Thouret, V., Cammas, J.-P., and Nédélec, P.: Tropospheric ozone climatology over Beijing: analysis of aircraft data from the MOZAIC program, Atmos. Chem. Phys., 8, 1-13, doi:10.5194/acp-8-1-2008, 2008.
Donat, M., Alexander, L., Yang, H., Durre, I., Vose, R., and Caesar, J.: Global Land-Based Datasets for Monitoring Climatic Extremes, B. Am. Meteorol. Soc., 94, 997-1006, doi:10.1175/Bams-D-12-00109.1, 2013.

Donner, L. J., Wyman, B. L., Hemler, R. S., et al.: The Dynamical Core, Physical Parameterizations, and Basic Simulation Characteristics of the Atmospheric Component AM3 of the GFDL Global Coupled Model CM3, J. Climate, 24, 3484-3519, doi:10.1175/2011jcli3955.1, 2011.

Duncan, B. N., Lamsal, L. N., Thompson, A. M., Yoshida, Y., Lu, Z. F., Streets, D. G., Hurwitz, M. M., and Pickering, K. E.: A space-based, high-resolution view of notable changes in urban $\mathrm{NO}_{x}$ pollution around the world (2005-2014), J. Geophys. Res., 121, 976-996, doi:10.1002/2015jd024121, 2016.

Emberson, L. D., Kitwiroon, N., Beevers, S., Büker, P., and Cinderby, S.: Scorched Earth: how will changes in the strength of the vegetation sink to ozone deposition affect human health and ecosystems?, Atmos. Chem. Phys., 13, 6741-6755, doi:10.5194/acp-13-6741-2013, 2013.

Federal Register: US Environmental Protection Agency, National Ambient Air Quality Standards for Ozone - Final Rule, Federal Register 80, available at: http://www.gpo.gov/fdsys/pkg/ FR-2015-10-26/pdf/2015-26594.pdf, 65292-65468, 2015.

Fiore, A. M., Dentener, F. J., Wild, O., et al.: Multimodel estimates of intercontinental source-receptor relationships for ozone pollution, J. Geophys. Res., 114, D04301, doi:10.1029/2008jd010816, 2009.

Fiore, A. M., Oberman, J. T., Lin, M. Y., Zhang, L., Clifton, O. E., Jacob, D. J., Naik, V., Horowitz, L. W., and Pinto, J. P.: Estimating North American background ozone in U.S. surface air with two independent global models: Variability, uncertainties, and recommendations Atmos. Environ., 96, 284-300, doi:10.1016/j.atmosenv.2014.07.045, 2014.

Fiore, A. M., Naik, V., and Leibensperger, E. M.: Air Quality and Climate Connections, J. Air Waste Manage., 65, 645-685, doi:10.1080/10962247.2015.1040526, 2015.

Gao, Y., Fu, J. S., Drake, J. B., Lamarque, J.-F., and Liu, Y.: The impact of emission and climate change on ozone in the United States under representative concentration pathways (RCPs), Atmos. Chem. Phys., 13, 9607-9621, doi:10.5194/acp-13-96072013, 2013.

Gilman, J. B., Lerner, B. M., Kuster, W. C., and de Gouw, J. A.: Source Signature of Volatile Organic Compounds from Oil and Natural Gas Operations in Northeastern Colorado, Environ. Sci. Technol., 47, 1297-1305, doi:10.1021/es304119a, 2013.

Granier, C., Bessagnet, B., Bond, T., D’Angiola, A., van der Gon, H. D., Frost, G. J., Heil, A., Kaiser, J. W., Kinne, S., Klimont, Z., Kloster, S., Lamarque, J.-F., Liousse, C., Masui, T., Meleux, F., Mieville, A., Ohara, T., Raut, J.-C., Riahi, K., Schultz, M. G., Smith, S. J., Thompson, A., van Aardenne, J., van der Werf, G. R., and van Vuuren, D. P.: Evolution of anthropogenic and biomass burning emissions of air pollutants at global and regional scales during the 1980-2010 period, Climatic Change, 109, 163-190, doi:10.1007/s10584-011-0154-1, 2011.

Gratz, L. E., Jaffe, D. A., and Hee, J. R.: Causes of increasing ozone and decreasing carbon monoxide in springtime at the Mt. Bachelor Observatory from 2004 to 2013, Atmos. Environ., 109, 323330, doi:10.1016/j.atmosenv.2014.05.076, 2014. 
Guenther, A., Karl, T., Harley, P., Wiedinmyer, C., Palmer, P. I., and Geron, C.: Estimates of global terrestrial isoprene emissions using MEGAN (Model of Emissions of Gases and Aerosols from Nature), Atmos. Chem. Phys., 6, 3181-3210, doi:10.5194/acp-63181-2006, 2006.

Halliday, H. S., Thompson, A. M., Wisthaler, A., Blake, D. R., Hornbrook, R. S., Mikoviny, T., Muller, M., Eichler, P., Apel, E. C., and Hills, A. J.: Atmospheric benzene observations from oil and gas production in the Denver-Julesburg Basin in July and August 2014, J. Geophys. Res.-Atmos., 121, 11055-11074, doi:10.1002/2016jd025327, 2016.

Harris, I., Jones, P. D., Osborn, T. J., and Lister, D. H.: Updated high-resolution grids of monthly climatic observations - the CRU TS3.10 Dataset, Int. J. Climatol., 34, 623-642, doi:10.1002/joc.3711, 2014.

Hilboll, A., Richter, A., and Burrows, J. P.: Long-term changes of tropospheric $\mathrm{NO}_{2}$ over megacities derived from multiple satellite instruments, Atmos. Chem. Phys., 13, 4145-4169, doi:10.5194/acp-13-4145-2013, 2013.

Horton, D. E., Johnson, N. C., Singh, D., Swain, D. L., Rajaratnam, B., and Diffenbaugh, N. S.: Contribution of changes in atmospheric circulation patterns to extreme temperature trends, Nature, 522, 465-469, doi:10.1038/nature14550, 2015.

Huang, L., McDonald-Buller, E. C., McGaughey, G., Kimura, Y., and Allen, D. T.: The impact of drought on ozone dry deposition over eastern Texas, Atmos. Environ., 127, 176-186, doi:10.1016/j.atmosenv.2015.12.022, 2016.

Huang, M., Carmichael, G. R., Chai, T., Pierce, R. B., Oltmans, S. J., Jaffe, D. A., Bowman, K. W., Kaduwela, A., Cai, C., Spak, S. N., Weinheimer, A. J., Huey, L. G., and Diskin, G. S.: Impacts of transported background pollutants on summertime western US air quality: model evaluation, sensitivity analysis and data assimilation, Atmos. Chem. Phys., 13, 359-391, doi:10.5194/acp-13359-2013, 2013.

Jacob, D. J. and Winner, D. A.: Effect of climate change on air quality, Atmos. Environ., 43, 51-63, doi:10.1016/j.atmosenv.2008.09.051, 2009.

Jacob, D. J., Logan, J. A., and Murti, P. P.: Effect of rising Asian emissions on surface ozone in the United States, Geophys. Res. Lett., 26, 2175-2178, doi:10.1029/1999g1900450, 1999.

Jaffe, D.: Relationship between Surface and Free Tropospheric Ozone in the Western U.S, Environ. Sci. Technol, 45, 432-438, doi:10.1021/es1028102, 2011.

Jaffe, D. and Ray, J.: Increase in surface ozone at rural sites in the western US, Atmos. Environ., 41, 5452-5463, doi:10.1016/j.atmosenv.2007.02.034, 2007.

Jaffe, D., Chand, D., Hafner, W., Westerling, A., and Spracklen, D.: Influence of fires on ozone concentrations in the western US, Environ. Sci. Technol., 42, 5885-5891, doi:10.1021/es800084k, 2008

Jaffe, D., Wigder, N., Downey, N., Pfister, G., Boynard, A., and Reid, S. B.: Impact of Wildfires on Ozone Exceptional Events in the Western US, Environ. Sci. Technol., 47, 11065-11072, doi:10.1021/es402164f, 2013.

Jia, L. W., Vecchi, G. A., Yang, X. S., Gudgel, R. G., Delworth, T. L., Stern, W. F., Paffendorf, K., Underwood, S. D., and Zeng, F. R.: The Roles of Radiative Forcing, Sea Surface Temperatures, and Atmospheric and Land Initial Conditions in US Summer
Warming Episodes, J. Climate, 29, 4121-4135, doi:10.1175/JcliD-15-0471.1, 2016.

John, J. G., Fiore, A. M., Naik, V., Horowitz, L. W., and Dunne, J. P.: Climate versus emission drivers of methane lifetime against loss by tropospheric OH from 1860-2100, Atmos. Chem. Phys., 12, 12021-12036, doi:10.5194/acp-12-12021-2012, 2012.

Koumoutsaris, S. and Bey, I.: Can a global model reproduce observed trends in summertime surface ozone levels?, Atmos. Chem. Phys., 12, 6983-6998, doi:10.5194/acp-12-6983-2012, 2012.

Krotkov, N. A., McLinden, C. A., Li, C., Lamsal, L. N., Celarier, E. A., Marchenko, S. V., Swartz, W. H., Bucsela, E. J., Joiner, J., Duncan, B. N., Boersma, K. F., Veefkind, J. P., Levelt, P. F., Fioletov, V. E., Dickerson, R. R., He, H., Lu, Z., and Streets, D. G.: Aura OMI observations of regional $\mathrm{SO}_{2}$ and $\mathrm{NO}_{2}$ pollution changes from 2005 to 2015, Atmos. Chem. Phys., 16, 46054629, doi:10.5194/acp-16-4605-2016, 2016.

Lamarque, J.-F., Bond, T. C., Eyring, V., Granier, C., Heil, A., Klimont, Z., Lee, D., Liousse, C., Mieville, A., Owen, B., Schultz, M. G., Shindell, D., Smith, S. J., Stehfest, E., Van Aardenne, J., Cooper, O. R., Kainuma, M., Mahowald, N., McConnell, J. R., Naik, V., Riahi, K., and van Vuuren, D. P.: Historical (1850-2000) gridded anthropogenic and biomass burning emissions of reactive gases and aerosols: methodology and application, Atmos. Chem. Phys., 10, 7017-7039, doi:10.5194/acp10-7017-2010, 2010.

Lamarque, J. F., Kyle, G. P., Meinshausen, M., Riahi, K., Smith, S. J., van Vuuren, D. P., Conley, A. J., and Vitt, F.: Global and regional evolution of short-lived radiatively-active gases and aerosols in the Representative Concentration Pathways, Climatic Change 109, 191-212, doi:10.1007/s10584-011-0155-0, 2012.

Langford, A. O., Aikin, K. C., Eubank, C. S., and Williams, E. J.: Stratospheric contribution to high surface ozone in Colorado during springtime, Geophys. Res. Lett., 36, L12801, doi:10.1029/2009g1038367, 2009.

Langford, A. O., Senff, C. J., Alvarez II, R. J., Banta, R. M., and Hardesty, R. M.: Long-range transport of ozone from the Los Angeles Basin: A case study, Geophys. Res. Lett., 37, L06807, doi:10.1029/2010g1042507, 2010.

Langford, A. O., Senff, C., Alvarez II, R., Brioude, J., Cooper, O., Holloway, J., Lin, M., Marchbanks, R., Pierce, R., Sandberg, S., Weickmann, A., and Williams, E.: An overview of the 2013 Las Vegas Ozone Study (LVOS): Impact of stratospheric intrusions and long-range transport on surface air quality, Atmos. Environ., 109, 305-322, doi:10.1016/j.atmosenv.2014.08.040, 2014.

Lee, H.-J., Kim, S.-W., Brioude, J., Cooper, O. R., Frost, G. J., Kim, C.-H., Park, R. J., Trainer, M., and Woo, J.-H.: Transport of $\mathrm{NO}_{x}$ in East Asia identified by satellite and in situ measurements and Lagrangian particle dispersion model simulations, J. Geophys. Res.-Atmos., 119, 2574-2596, doi:doi:10.1002/2013JD021185, 2014.

Leibensperger, E. M., Mickley, L. J., and Jacob, D. J.: Sensitivity of US air quality to mid-latitude cyclone frequency and implications of 1980-2006 climate change, Atmos. Chem. Phys., 8, 7075-7086, doi:10.5194/acp-8-7075-2008, 2008.

Li, G., Bei, N., Cao, J., Wu, J., Long, X., Feng, T., Dai, W., Liu, S., Zhang, Q., and Tie, X.: Widespread and Persistent Ozone Pollution in Eastern China, Atmos. Chem. Phys. Discuss., doi:10.5194/acp-2016-864, in review, 2016. 
Lin, M., Holloway, T., Oki, T., Streets, D. G., and Richter, A.: Multiscale model analysis of boundary layer ozone over East Asia, Atmos. Chem. Phys., 9, 3277-3301, doi:10.5194/acp-9-3277-2009, 2009.

Lin, M., Holloway, T., Carmichael, G. R., and Fiore, A. M.: Quantifying pollution inflow and outflow over East Asia in spring with regional and global models, Atmos. Chem. Phys., 10, 42214239, doi:10.5194/acp-10-4221-2010, 2010.

Lin, M., Fiore, A. M., Cooper, O. R., Horowitz, L. W., Langford, A. O., Levy, H., Johnson, B. J., Naik, V., Oltmans, S. J., and Senff, C. J.: Springtime high surface ozone events over the western United States: Quantifying the role of stratospheric intrusions, J. Geophys. Res., 117, D00V22, doi:10.1029/2012jd018151, 2012a.

Lin, M., Fiore, A. M., Horowitz, L. W., Cooper, O. R., Naik, V., Holloway, J., Johnson, B. J., Middlebrook, A. M., Oltmans, S. J., Pollack, I. B., Ryerson, T. B., Warner, J. X., Wiedinmyer, C., Wilson, J., and Wyman, B.: Transport of Asian ozone pollution into surface air over the western United States in spring, J. Geophys. Res., 117, D00V07, doi:10.1029/2011jd016961, 2012b.

Lin, M., Horowitz, L. W., Oltmans, S. J., Fiore, A. M., and Fan, S.: Tropospheric ozone trends at Mauna Loa Observatory tied to decadal climate variability, Nat. Geosci., 7, 136-143, doi:10.1038/ngeo2066, 2014

Lin, M., Fiore, A. M., Horowitz, L. W., Langford, A. O., Oltmans, S. J., Tarasick, D., and Rieder, H. E.: Climate variability modulates western U.S. ozone air quality in spring via deep stratospheric intrusions, Nat. Commun., 6, 7105, doi:10.1038/ncomms8105, $2015 \mathrm{a}$.

Lin, M., Horowitz, L. W., Cooper, O. R., Tarasick, D., Conley, S., Iraci, L. T., Johnson, B., Leblanc, T., Petropavlovskikh, I., and Yates, E. L.: Revisiting the evidence of increasing springtime ozone mixing ratios in the free troposphere over western North America, Geophys. Res. Lett., 42, 8719-8728, doi:10.1002/2015GL065311, 2015b.

Lin, Y.-K., Lin, T.-H., and Chang, S.-C.: The changes in different ozone metrics and their implications following precursor reductions over northern Taiwan from 1994 to 2007, Environ. Monit. Assess., 169, 143-157, doi:10.1007/s10661-009-1158-4, 2010.

Liu, F., Zhang, Q., Ronald, J. V., Zheng, B., Tong, D., Yan, L., Zheng, Y. X., and He, K. B.: Recent reduction in $\mathrm{NO}_{x}$ emissions over China: synthesis of satellite observations and emission inventories, Environ. Res. Lett., 11, 114002, doi:10.1088/17489326/11/11/114002, 2016.

Liu, H. Y., Jacob, D. J., Chan, L. Y., Oltmans, S. J., Bey, I., Yantosca, R. M., Harris, J. M., Duncan, B. N., and Martin, R. V.: Sources of tropospheric ozone along the Asian Pacific Rim: An analysis of ozonesonde observations, J. Geophys. Res., 107, 4573, doi:10.1029/2001jd002005, 2002.

Loughner, C. P., Duncan, B. N., and Hains, J.: The benefit of historical air pollution emissions reductions during extreme heat, Environ. Manage., 9, 34-38, 2014.

Ma, Z., Xu, J., Quan, W., Zhang, Z., Lin, W., and Xu, X.: Significant increase of surface ozone at a rural site, north of eastern China, Atmos. Chem. Phys., 16, 3969-3977, doi:10.5194/acp-16-39692016, 2016.

McDonald, B. C., Dallmann, T. R., Martin, E. W., and Harley, R. A.: Long-term trends in nitrogen oxide emissions from motor vehicles at national, state, and air basin scales, J. Geophys. Res., 117, D00V18, doi:10.1029/2012jd018304, 2012.

McDuffie, E. E., Edwards, P. M., Gilman, J. B., Lerner, B. M., Dube, W. P., Trainer, M., Wolfe, D. E., Angevine, W. M., deGouw, J., Williams, E. J., Tevlin, A. G., Murphy, J. G., Fischer, E. V., McKeen, S., Ryerson, T. B., Peischl, J., Holloway, J. S., Aikin, K., Langford, A. O., Senff, C. J., Alvarez, R. J., Hall, S. R., Ullmann, K., Lantz, K. O., and Brown, S. S.: Influence of oil and gas emissions on summertime ozone in the Colorado Northern Front Range, J. Geophys. Res.-Atmos., 121, 8712-8729, doi:10.1002/2016jd025265, 2016.

Monks, P. S., Archibald, A. T., Colette, A., Cooper, O., Coyle, M., Derwent, R., Fowler, D., Granier, C., Law, K. S., Mills, G. E., Stevenson, D. S., Tarasova, O., Thouret, V., von Schneidemesser, E., Sommariva, R., Wild, O., and Williams, M. L.: Tropospheric ozone and its precursors from the urban to the global scale from air quality to short-lived climate forcer, Atmos. Chem. Phys., 15, 8889-8973, doi:10.5194/acp-15-8889-2015, 2015.

Morgenstern, O., Hegglin, M. I., Rozanov, E., O’Connor, F. M., Abraham, N. L., Akiyoshi, H., Archibald, A. T., Bekki, S., Butchart, N., Chipperfield, M. P., Deushi, M., Dhomse, S. S., Garcia, R. R., Hardiman, S. C., Horowitz, L. W., Jöckel, P., Josse, B., Kinnison, D., Lin, M., Mancini, E., Manyin, M. E., Marchand, M., Marécal, V., Michou, M., Oman, L. D., Pitari, G., Plummer, D. A., Revell, L. E., Saint-Martin, D., Schofield, R., Stenke, A., Stone, K., Sudo, K., Tanaka, T. Y., Tilmes, S., Yamashita, Y., Yoshida, K., and Zeng, G.: Review of the global models used within phase 1 of the Chemistry-Climate Model Initiative (CCMI), Geosci. Model Dev., 10, 639-671, doi:10.5194/gmd-10-639-2017, 2017.

Naik, V., Horowitz, L. W., Fiore, A. M., Ginoux, P., Mao, J. Q., Aghedo, A. M., and Levy, H.: Impact of preindustrial to presentday changes in short-lived pollutant emissions on atmospheric composition and climate forcing, J. Geophys. Res., 118, 80868110, doi:10.1002/jgrd.50608, 2013.

Parrish, D. D., Lamarque, J.-F., Naik, V., Horowitz, L., Shindell, D. T., Staehelin, J., Derwent, R., Cooper, O. R., Tanimoto, H., Volz-Thomas, A., Gilge, S., Scheel, H.-E., Steinbacher, M., and Frühlich, M.: Long-term changes in lower tropospheric baseline ozone concentrations: Comparing chemistry-climate models and observations at northern midlatitudes, J. Geophys. Res., 119, 5719-5736, doi:10.1002/2013JD021435, 2014.

Pfister, G. G., Walters, S., Emmons, L. K., Edwards, D. P., and Avise, J.: Quantifying the contribution of inflow on surface ozone over California during summer 2008, J. Geophys. Res., 118, 12282-12299, doi:10.1002/2013jd020336, 2013.

Pfister, G. G., Walters, S., Lamarque, J. F., Fast, J., Barth, M. C., Wong, J., Done, J., Holland, G., and Bruyere, C. L.: Projections of future summertime ozone over the US, J. Geophys. Res., 119, 5559-5582, doi:10.1002/2013jd020932, 2014.

Porter, W. C., Heald, C. L., Cooley, D., and Russell, B.: Investigating the observed sensitivities of air-quality extremes to meteorological drivers via quantile regression, Atmos. Chem. Phys., 15, 10349-10366, doi:10.5194/acp-15-10349-2015, 2015.

Pusede, S. E., Steiner, A. L., and Cohen, R. C.: Temperature and Recent Trends in the Chemistry of Continental Surface Ozone, Chem. Rev., 115, 3898-3918, doi:10.1021/cr5006815, 2015.

Rasmussen, D. J., Fiore, A. M., Naik, V., Horowitz, L. W., McGinnis, S. J., and Schultz, M. G.: Surface ozone-temperature rela- 
tionships in the eastern US: A monthly climatology for evaluating chemistry-climate models, Atmos. Environ., 47, 142-153, doi:10.1016/j.atmosenv.2011.11.021, 2012.

Reidmiller, D. R., Fiore, A. M., Jaffe, D. A., Bergmann, D., Cuvelier, C., Dentener, F. J., Duncan, B. N., Folberth, G., Gauss, M., Gong, S., Hess, P., Jonson, J. E., Keating, T., Lupu, A., Marmer, E., Park, R., Schultz, M. G., Shindell, D. T., Szopa, S., Vivanco, M. G., Wild, O., and Zuber, A.: The influence of foreign vs. North American emissions on surface ozone in the US, Atmos. Chem. Phys., 9, 5027-5042, doi:10.5194/acp-9-5027-2009, 2009

Rieder, H. E., Fiore, A. M., Horowitz, L. W., and Naik, V.: Projecting policy-relevant metrics for high summertime ozone pollution events over the eastern United States due to climate and emission changes during the 21 st century, J. Geophys. Res., 120, 784-800, doi:10.1002/2014jd022303, 2015.

Russell, A. R., Valin, L. C., and Cohen, R. C.: Trends in $\mathrm{OMI} \mathrm{NO}_{2}$ observations over the United States: effects of emission control technology and the economic recession, Atmos. Chem. Phys., 12, 12197-12209, doi:10.5194/acp-12-12197-2012, 2012.

Schnell, J. L., Prather, M. J., Josse, B., Naik, V., Horowitz, L. W., Zeng, G., Shindell, D. T., and Faluvegi, G.: Effect of climate change on surface ozone over North America, Europe, and East Asia, Geophys. Res. Lett., 43, 3509-3518, doi:10.1002/2016GL068060, 2016.

Schultz, M. G., Heil, A., Hoelzemann, J. J., Spessa, A., Thonicke, K., Goldammer, J. G., Held, A. C., Pereira, J. M. C., and van het Bolscher, M.: Global wildland fire emissions from 1960 to 2000, Global Biogeochem. Cy., 22, Gb2002, doi:10.1029/2007gb003031, 2008 .

Schwietzke, S., Sherwood, O. A., Ruhwiler, L. M. P. B., Miller, J. B., Etiope, G., Dlugokencky, E. J., Michel, S. E., Arling, V. A., Vaughn, B. H., White, J. W. C., and Tans, P. P.: Upward revision of global fossil fuel methane emissions based on isotope database, Nature, 538, 88-91, doi:10.1038/nature19797, 2016.

Seager, R. and Hoerling, M.: Atmosphere and Ocean Origins of North American Droughts, J. Climate, 27, 4581-4606, doi:10.1175/Jcli-D-13-00329.1, 2014.

Shen, L., Mickley, L. J., and Gilleland, E.: Impact of increasing heat waves on US ozone episodes in the 2050s: Results from a multimodel analysis using extreme value theory, Geophys. Res. Lett., 43, 4017-4025, doi:10.1002/2016gl068432, 2016.

Shepherd, T. G.: CLIMATE SCIENCE: The dynamics of temperature extremes, Nature, 522, 422-424, 2015.

Simon, H., Reff, A., Wells, B., Xing, J., and Frank, N.: Ozone Trends Across the United States over a Period of Decreasing $\mathrm{NO}_{x}$ and VOC Emissions, Environ. Sci. Technol., 49, 186-195, doi:10.1021/es504514z, 2015.

Solberg, S., Hov, O., Sovde, A., Isaksen, I. S. A., Coddeville, P., De Backer, H., Forster, C., Orsolini, Y., and Uhse, K.: European surface ozone in the extreme summer 2003, J. Geophys. Res., 113, D07307, doi:10.1029/2007jd009098, 2008.

Strode, S. A., Rodriguez, J. M., Logan, J. A., Cooper, O. R., Witte, J. C., Lamsal, L. N., Damon, M., Van Aartsen, B., Steenrod, S. D., and Strahan, S. E.: Trends and variability in surface ozone over the United States, J. Geophys. Res.-Atmos., 120, 9020-9042, doi:10.1002/2014JD022784, 2015.

Sun, L., Xue, L., Wang, T., Gao, J., Ding, A., Cooper, O. R., Lin, M., Xu, P., Wang, Z., Wang, X., Wen, L., Zhu, Y., Chen, T.,
Yang, L., Wang, Y., Chen, J., and Wang, W.: Significant increase of summertime ozone at Mount Tai in Central Eastern China, Atmos. Chem. Phys., 16, 10637-10650, doi:10.5194/acp16-10637-2016, 2016.

Tanimoto, H.: Increase in springtime tropospheric ozone at a mountainous site in Japan for the period 1998-2006, Atmos. Environ. 43, 1358-1363, doi:10.1016/j.atmosenv.2008.12.006, 2009.

Tanimoto, H., Zbinden, R. M., Thouret, V., and Nedelec, P.: Consistency of tropospheric ozone observations made by different platforms and techniques in the global databases, Tellus B, 67, 27073, doi:10.3402/tellusb.v67.27073, 2016.

Thompson, A. M., Witte, J. C., Smit, H. G. J., Oltmans, S. J., Johnson, B. J., Kirchhoff, V. W. J. H., and Schmidlin, F. J.: Southern Hemisphere Additional Ozonesondes (SHADOZ) 1998-2004 tropical ozone climatology: 3. Instrumentation, station-to-station variability, and evaluation with simulated flight profiles, J. Geophys. Res., 112, D03304, doi:10.1029/2005jd007042, 2007.

Travis, K. R., Jacob, D. J., Fisher, J. A., Kim, P. S., Marais, E. A., Zhu, L., Yu, K., Miller, C. C., Yantosca, R. M., Sulprizio, M. P., Thompson, A. M., Wennberg, P. O., Crounse, J. D., St. Clair, J. M., Cohen, R. C., Laughner, J. L., Dibb, J. E., Hall, S. R., Ullmann, K., Wolfe, G. M., Pollack, I. B., Peischl, J., Neuman, J. A., and Zhou, X.: Why do models overestimate surface ozone in the Southeast United States?, Atmos. Chem. Phys., 16, 1356113577, doi:10.5194/acp-16-13561-2016, 2016.

van der Werf, G. R., Randerson, J. T., Giglio, L., Collatz, G. J., Mu, M., Kasibhatla, P. S., Morton, D. C., DeFries, R. S., Jin, Y., and van Leeuwen, T. T.: Global fire emissions and the contribution of deforestation, savanna, forest, agricultural, and peat fires (19972009), Atmos. Chem. Phys., 10, 11707-11735, doi:10.5194/acp10-11707-2010, 2010.

VanCuren, R. and Gustin, M. S.: Identification of sources contributing to $\mathrm{PM}_{2.5}$ and ozone at elevated sites in the western US by receptor analysis: Lassen Volcanic National Park, California, and Great Basin National Park, Nevada, Sci. Total Environ., 530, 505-518, doi:10.1016/j.scitotenv.2015.03.091, 2015.

Verstraeten, W. W., Neu, J. L., Williams, J. E., Bowman, K. W., Worden, J. R., and Boersma, K. F.: Rapid increases in tropospheric ozone production and export from China, Nat. Geosci., 8, 690-695, doi:10.1038/Ngeo2493, 2015.

Wang, T., Ding, A. J., Gao, J., and Wu, W. S.: Strong ozone production in urban plumes from Beijing, China, Geophys. Res. Lett., 33, L21806, doi:10.1029/2006g1027689, 2006.

Wang, T., Wei, X. L., Ding, A. J., Poon, C. N., Lam, K. S., Li, Y. S., Chan, L. Y., and Anson, M.: Increasing surface ozone concentrations in the background atmosphere of Southern China, 19942007, Atmos. Chem. Phys., 9, 6217-6227, doi:10.5194/acp-96217-2009, 2009.

Wang, Y., McElroy, M. B., Munger, J. W., Hao, J., Ma, H., Nielsen, C. P., and Chen, Y.: Variations of $\mathrm{O}_{3}$ and $\mathrm{CO}$ in summertime at a rural site near Beijing, Atmos. Chem. Phys., 8, 6355-6363, doi:10.5194/acp-8-6355-2008, 2008

Wang, Y., Xie, Y., Cai, L., Dong, W., Zhang, Q., and Zhang, L.: Impact of the 2011 Southern US Drought on Ground-Level Fine Aerosol Concentration in Summertime, J. Atmos. Sci., 72, 10751093, doi:10.1175/jas-d-14-0197.1, 2015.

Warneke, C., de Gouw, J. A., Holloway, J. S., Peischl, J., Ryerson, T. B., Atlas, E., Blake, D., Trainer, M., and Parrish, D. D.: Multiyear trends in volatile organic compounds in Los Angeles, Cal- 
ifornia: Five decades of decreasing emissions, J. Geophys. Res., 117, D00v17, doi:10.1029/2012jd017899, 2012.

Xu, W., Lin, W., Xu, X., Tang, J., Huang, J., Wu, H., and Zhang, $\mathrm{X}$.: Long-term trends of surface ozone and its influencing factors at the Mt Waliguan GAW station, China - Part 1: Overall trends and characteristics, Atmos. Chem. Phys., 16, 6191-6205, doi:10.5194/acp-16-6191-2016, 2016.

Yang, J., Tian, H. Q., Tao, B., Ren, W., Pan, S. F., Liu, Y. Q., and Wang, Y. H.: A growing importance of large fires in conterminous United States during 1984-2012, J. Geophys. Res.-Biogeo., 120, 2625-2640, doi:10.1002/2015jg002965, 2015.

Yurganov, L. N., Duchatelet, P., Dzhola, A. V., Edwards, D. P., Hase, F., Kramer, I., Mahieu, E., Mellqvist, J., Notholt, J., Novelli, P. C., Rockmann, A., Scheel, H. E., Schneider, M., Schulz, A., Strandberg, A., Sussmann, R., Tanimoto, H., Velazco, V., Drummond, J. R., and Gille, J. C.: Increased Northern Hemispheric carbon monoxide burden in the troposphere in 2002 and 2003 detected from the ground and from space, Atmos. Chem. Phys., 5, 563-573, doi:10.5194/acp-5-563-2005, 2005.
Zhang, L., Jacob, D. J., Boersma, K. F., Jaffe, D. A., Olson, J. R., Bowman, K. W., Worden, J. R., Thompson, A. M., Avery, M. A., Cohen, R. C., Dibb, J. E., Flock, F. M., Fuelberg, H. E., Huey, L. G., McMillan, W. W., Singh, H. B., and Weinheimer, A. J.: Transpacific transport of ozone pollution and the effect of recent Asian emission increases on air quality in North America: an integrated analysis using satellite, aircraft, ozonesonde, and surface observations, Atmos. Chem. Phys., 8, 6117-6136, doi:10.5194/acp-8-6117-2008, 2008.

Zhang, L., Jacob, D. J., Yue, X., Downey, N. V., Wood, D. A., and Blewitt, D.: Sources contributing to background surface ozone in the US Intermountain West, Atmos. Chem. Phys., 14, 52955309, doi:10.5194/acp-14-5295-2014, 2014.

Zhang, Y. Q., Cooper, O. R., Gaudel, A., Thompson, A. M., Nedelec, P., Ogino, S. Y., and West, J. J.: Tropospheric ozone change from 1980 to 2010 dominated by equatorward redistribution of emissions, Nat. Geosci., 9, 875-879, doi:10.1038/Ngeo2827, 2016. 